\title{
Phosphine Ligand-Free Bimetallic Ni(0)Pd(0) Nanoparticles as a Catalyst for Facile, General, Sustainable, and Highly Selective 1,4-Reductions in Aqueous Micelles
}

Deborah Ogulu, ${ }^{\dagger \dagger}$ Pranjal P. Bora,${ }^{\dagger \dagger}$ Manisha Bihani, ${ }^{\dagger}$ Sudripet Sharma, ${ }^{\dagger}$ Tharique N. Ansari,${ }^{\dagger}$ Andrew J. Wilson,${ }^{\dagger}$ Jacek B. Jasinski,${ }^{\S}$ Fabrice Gallou, ${ }^{\|}$Sachin Handa ${ }^{\dagger *}$ $\lceil 2320$ S. Brook Street, Department of Chemistry, University of Louisville, Louisville, Kentucky 40292, United States

\$Materials Characterization, Conn Center for Renewable Energy Research, University of Louisville, Louisville, Kentucky 40292, United States

"Novartis Pharma AG, Basel, 4056, Switzerland

$\$$ These authors contributed equally to this work

*sachin.handa@louisville.edu

\section{Contents}

1. General experimental details

2. Synthesis and isolation of nanoparticles

3. Catalytic activity and selectivity

4. Optimizations

5. Control experiments

6. Optimized catalytic reaction procedure

7. Substrate scope

8. Gram-scale reaction

9. Detailed analysis of nanoparticles

10. Analytical data

11. References

12. NMR spectra

\section{Pages}

S1-S2

S3

S4-S7

S8-S10

S11-S13

S14

S15-S16

S17

S18-S25

S26-S36

S37

S38-S69 


\section{GENERAL EXPERIMENTAL DETAILS}

All manipulations were carried out under air unless otherwise noted. Solvent molarity listed in reaction schemes is relative to the limiting reagent.

\subsection{Chemicals and Supply}

Chromatography: TLC plates (UV 254 indicator, aluminum backed, 175-225 $\mu \mathrm{m}$ thickness, standard grade silica gel, 230-400 mesh) was supplied by Merck; silica gel (60 Å pore size, 230400 mesh) was purchased from Silicycle; sand was purchased from Fisher Chemical.

Solvents: Acetone, ethyl acetate, hexanes, and HPLC-grade water were purchased from Fisher Chemical; NMR solvents were obtained from Cambridge Isotopes Laboratories; dry solvents were prepared using standard procedures; surfactant solutions were prepared in HPLC-grade water; PS-750-M was prepared as previously reported or prepared by a procedure used by MilliporeSigma; ${ }^{1}$ poly(ethylene glycol) methyl ether 750 (MPEG-750-M) was supplied by AlfaAesar.

Reagents: $\mathrm{Pd}(\mathrm{OAc})_{2}$ was purchased from Chem-Impex Inc. and Sigma Aldrich. Ni(OAc) $)_{2}$ was purchased from Strem Chemicals. 3.0 M Methylmagnesium bromide solution in diethyl ether and $\mathrm{NaH}$ were purchased from Sigma-Aldrich. PMHS was purchased from Alfa-Aesar. $\mathrm{NaBH}_{4}$ was purchased from Strem Chemicals, Inc. TPSiH was purchased from Peninsular ChemResearch Inc. Benzyl bromides were supplied by TCI, Alfa-Aesar, Sigma-Aldrich or Combi-Blocks Inc. Triisopropylsilyl alcohol was supplied by Alfa-Aesar. Sodium bicarbonate and anhydrous potassium carbonate were purchased from Fisher Scientific. Commercially available amines, aldehyde, alcohols, and other intermediates used were either supplied by Sigma-Aldrich or Combi-Blocks Inc. or Oakwood Chemicals.

\subsection{General Instrumentation}

All products were purified by flash chromatography using a Teledyne Isco CombiFlash $\mathrm{R}_{\mathrm{f}} 150$. GC-MS data was obtained using a Thermo Scientific Trace 1300 Gas Chromatograph coupled with a Thermo Scientific ISQ-QD Single Quadrupole Mass Spectrometer. NMR spectra were recorded at $23{ }^{\circ} \mathrm{C}$ on Varian MR-400, Varian Unity INOVA 500, and Varian VNMRS 700 spectrometers (400, 500 and $700 \mathrm{MHz}$, respectively). Reported chemical shifts are referenced to 
residual solvent peaks. Infrared absorbance spectra were acquired on a FTIR Perkin Elmer Spectrum Two: UATR Two spectrometer using $1 \mathrm{~cm}^{-1}$ resolution. High-resolution mass analyses were obtained either using a 5975C Mass Selective Detector coupled with a 7890A Gas Chromatograph (Agilent Technologies) or orbit-trap. Melting points were determined using a Thomas Hoover melting point apparatus with samples in Kimble Kimex 51 capillaries (1.5-1.8 x $90 \mathrm{~mm}$ ). High-resolution transmission electron microscopy was conducted with a $200 \mathrm{kV}$ FEI Tecnai F20 FEG-TEM/STEM. XPS analysis were conducted with a VG Scientific MultiLab 3000 ultrahigh vacuum surface analysis system equipped with CLAM4 hemispherical electron energy analyzer and a dual-mode $(\mathrm{Mg} / \mathrm{Al}) \mathrm{X}$-ray source operating at $15 \mathrm{kV}$ of voltage and $10 \mathrm{~mA}$ of emission current. 


\section{SYNTHESIS AND ISOLATION OF NANOPARTICLES}

In a flame-dried $10 \mathrm{~mL}$ microwave reaction vial containing PTFE-coated stir bar, $\mathrm{Ni}(\mathrm{OAc})_{2}$ (44.5 mg, $0.25 \mathrm{mmol})$ was added under the argon atmosphere. $\mathrm{Pd}(\mathrm{OAc})_{2}(2.24 \mathrm{mg}, 0.01 \mathrm{mmol})$ and $2.5 \mathrm{~mL}$ anhydrous THF was added to the reaction mixture under argon atmosphere. Reaction mixture was heated at $60{ }^{\circ} \mathrm{C}$ for 5 minutes and then mixture was allowed to cool to rt. $3.0 \mathrm{M}$ $\mathrm{MeMgBr}$ solution in diethyl ether $(0.33 \mathrm{~mL}, 1 \mathrm{mmol})$ was added to the reaction mixture. Upon addition of Grignard reagent, mixture turned to black color. Reaction mixture was stirred for 10 minutes at rt. $7.5 \mathrm{~mL}$ of $3.0 \mathrm{wt}$ \% aq. PS-750-M was added to the reaction mixture and mixture was stirred at rt. After 20 minutes, THF was removed under reduced pressure. The reaction mixture was then centrifuged, and water layer was removed, and the collected solid was dried under high vacuum overnight to obtain solid nanoparticles.

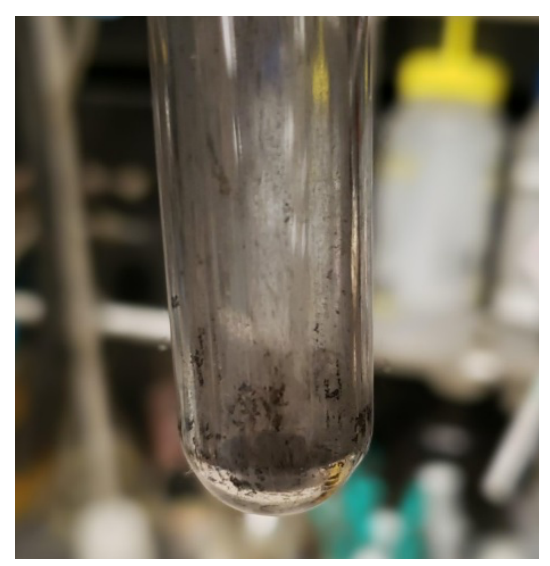

Figure S1. Solid nanoparticles in a vial. 


\section{CATALYTIC ACTIVITY AND SELECTIVITY}

\subsection{Hydrogenation with isolated Ni/Pd NPs}

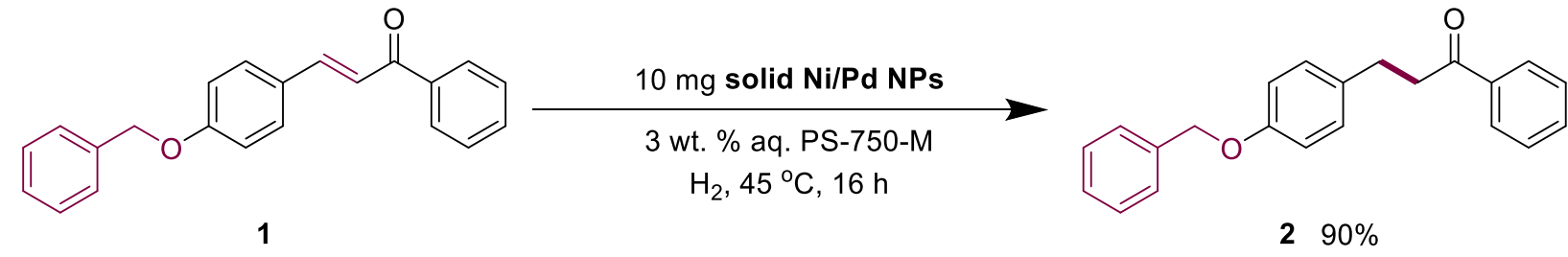

In a flame-dried $4 \mathrm{~mL}$ microwave reaction vial containing PTFE-coated stir bar, $10 \mathrm{mg}$ solid $\mathrm{Ni} / \mathrm{Pd} \mathrm{NP}$ catalyst was added under the argon atmosphere. $0.25 \mathrm{~mL}$ anhydrous THF and $0.75 \mathrm{~mL}$ 3.0 wt. $\%$ aq. PS-750-M were added to the reaction mixture and mixture was stirred for 5 minutes at rt. 1 (78 $\mathrm{mg}, 0.25 \mathrm{mmol}$ ) was added to the reaction mixture and septum was closed. Reaction mixture was evacuated and backfilled with hydrogen gas by introducing hydrogen balloon on the top of septum. Reaction mixture was stirred under hydrogen atmosphere at $45{ }^{\circ} \mathrm{C}$. After $16 \mathrm{~h}, 35 \mu \mathrm{L}$ mesitylene and $0.5 \mathrm{~mL}$ EtOAc were added to the reaction mixture, and it was stirred for a minute. Organic layer was separated with the help of syringe. EtOAc was added one more time and then separated from an aqueous layer. An aliquot (20-25 $\mu \mathrm{L})$ from combined organic layers was passed through a very small silica plug and then analyzed by GC-MS. Analysis showed complete conversion of $\mathbf{1}$ to $\mathbf{2}$. Remaining organic layers were dried over anhydrous $\mathrm{Na}_{2} \mathrm{SO}_{4}$. Volatiles were removed under reduced pressure to obtain crude product, which was purified by flash column chromatography over silica gel using EtOAc/hexanes as an eluent (pure hexanes, 2.5:7.5 EtOAc/hexanes) to obtain 2 as viscous oil (71 $\mathrm{mg}, 90 \%)$.

\subsection{Hydrogenation with isolated Ni/Pd NPs after exposed to air for $24 \mathrm{~h}$ prior to use}

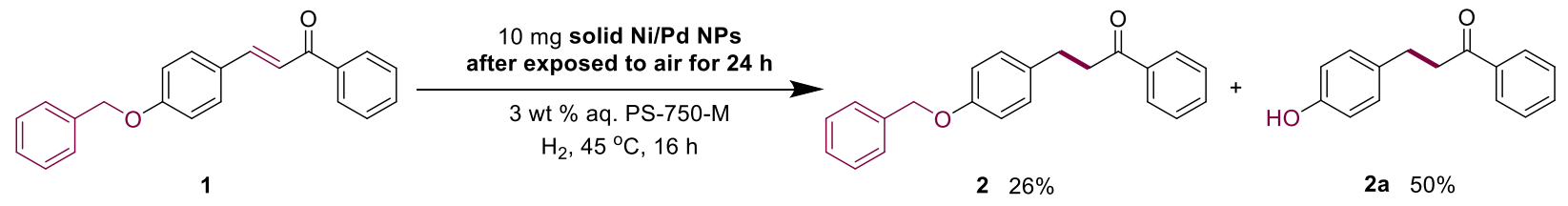


In a flame-dried $4 \mathrm{~mL}$ microwave reaction vial containing PTFE-coated stir bar, $10 \mathrm{mg}$ solid $\mathrm{Ni} / \mathrm{Pd} \mathrm{NP}$ catalyst, which was exposed to air for $24 \mathrm{~h}$, was added. $0.25 \mathrm{~mL}$ anhydrous THF and $0.75 \mathrm{~mL} 3.0 \mathrm{wt}$ \% $\%$ aq. PS-750-M were added to the reaction mixture and mixture was stirred for 5 minutes at rt. 1 (78 $\mathrm{mg}, 0.25 \mathrm{mmol}$ ) was added to the reaction mixture and septum was closed. Reaction mixture was evacuated and backfilled with hydrogen gas by introducing hydrogen balloon on the top of septum. Reaction mixture was stirred under hydrogen atmosphere at $45{ }^{\circ} \mathrm{C}$. After $16 \mathrm{~h}, 35 \mu \mathrm{L}$ mesitylene and $0.5 \mathrm{~mL}$ EtOAc was added to the reaction mixture, and it was stirred for a minute. Organic layer was separated with the help of syringe. EtOAc was added one more time and an aliquot $(20-25 \mu \mathrm{L})$ was passed through a very small silica plug and then analyzed by GCMS. Analysis showed loss of selectivity with the formation of both 2 (26\%) and 2a $(50 \%)$ along with unidentified byproduct.

\subsection{Hydrogenation with traditional $\mathrm{Pd} / \mathrm{C}$ catalyst}

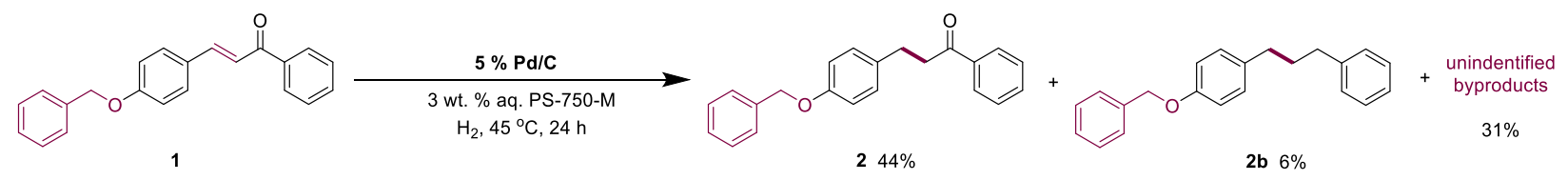

In a flame-dried $4 \mathrm{~mL}$ microwave reaction vial containing PTFE-coated stir bar, $5 \mathrm{~mol} \% \mathrm{Pd} / \mathrm{C}$ (5 wt. \%) was added under the argon atmosphere. $0.25 \mathrm{~mL}$ anhydrous THF and $0.75 \mathrm{~mL} 3.0 \mathrm{wt}$. $\%$ aq. PS-750-M were added to the reaction mixture and mixture was stirred for 5 minutes at rt. 1 (78 $\mathrm{mg}, 0.25 \mathrm{mmol}$ ) was added to the reaction mixture and septum was closed. Reaction mixture was evacuated and backfilled with hydrogen gas by introducing hydrogen balloon on the top of septum. Reaction mixture was stirred under hydrogen atmosphere at $45^{\circ} \mathrm{C}$.

After $24 \mathrm{~h}, 0.5 \mathrm{~mL}$ EtOAc was added to the reaction mixture, and it was stirred for a minute. Organic layer was separated with the help of syringe. EtOAc was added one more time and an aliquot (20-25 $\mu \mathrm{L})$ was passed through a very small silica plug and then analyzed by GC-MS. GC-MS analysis was based on unreacted starting material showed formation of 2 (44\%), the completely reduced product $\mathbf{2 b}(6 \%)$ and the formation of an unknown side product $(31 \%)$. 


\subsection{Hot filtration study.}

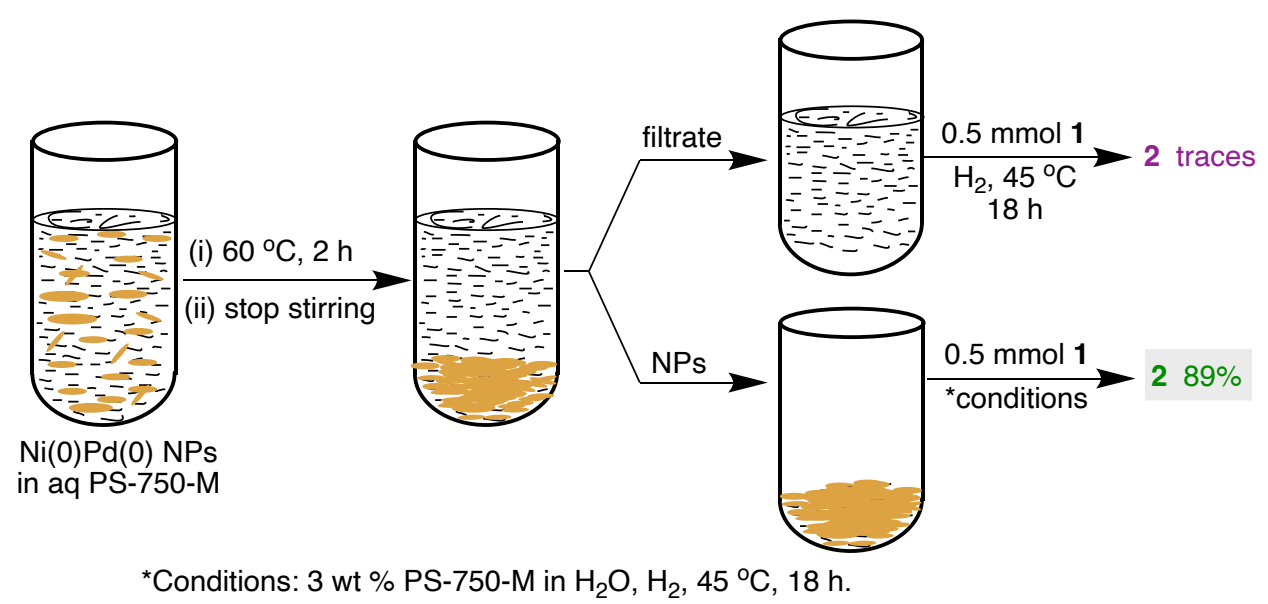

\section{Nanoparticle preparation}

In an oven-dried $4 \mathrm{~mL}$ reaction vial containing a PTFE-coated stir bar, $\mathrm{Ni}(\mathrm{OAc})_{2}(4.4 \mathrm{mg}, 5 \mathrm{~mol} \%$ for 0.5 mmol scale catalytic reaction) was added. Reaction flask was closed with a rubber septum and was evacuated and backfilled with argon. $\mathrm{Pd}(\mathrm{OAc})_{2}(0.22 \mathrm{mg}, 0.2 \mathrm{~mol} \%, 0.1 \mathrm{~mL}$ stock solution. The stock solution was prepared by dissolving $2.2 \mathrm{mg} \mathrm{Pd}(\mathrm{OAc})_{2}$ in $1 \mathrm{~mL} \mathrm{THF}$ ) was added to the reaction mixture under argon atmosphere and the resulting mixture was stirred for 5 minutes at $60{ }^{\circ} \mathrm{C}$. Reaction mixture was cooled to rt. $3.0 \mathrm{M} \mathrm{MeMgCl}$ solution in diethyl ether $(0.03 \mathrm{~mL}, 20 \mathrm{~mol} \%)$ was added dropwise to the reaction mixture at $\mathrm{rt}$. With the addition of Grignard reagent, the color of the mixture turned black. To the reaction mixture, $1.5 \mathrm{~mL} 3$ wt \% aqueous PS-750-M was added (PS-750-M was freshly purged with argon prior to use). The Reaction mixture was stirred for 2 hours at $60{ }^{\circ} \mathrm{C}$. After $2 \mathrm{~h}$, the reaction mixture was cooled to rt. The mixture was centrifuged for 5 minutes at $1200 \mathrm{rpm}$. The solid NPs were filtered off. The filtrate and nanoparticles were transferred into separate reaction vials (under argon atmosphere) for their activity tests.

\section{Activity test with solid nanoparticles}

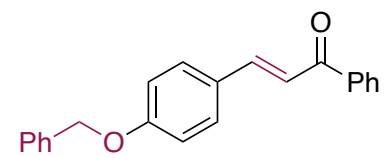

1

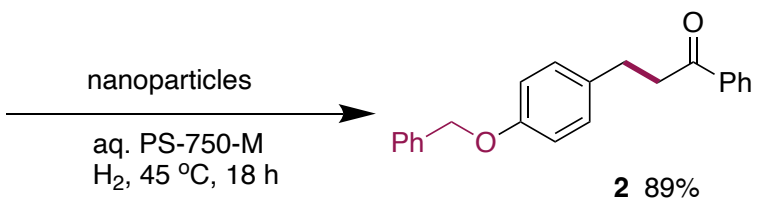

$289 \%$

To the solid NPs obtained above, freshly argon purged $1.5 \mathrm{~mL} 3$ wt \% aqueous PS-750-M was added under argon atmosphere. 1 (E)-3-(4-(benzyloxy)phenyl)-1-phenylprop-2-en-1-one (157 mg, $0.5 \mathrm{mmol}$ ) was dissolved in $0.5 \mathrm{~mL}$ dry THF and was added into the reaction mixture. The reaction mixture was evacuated and backfilled with argon for three times. Finally, the reaction mixture was carefully evacuated 
and backfilled with $\mathrm{H}_{2}$ using a balloon filled with hydrogen gas. The reaction mixture was stirred at $45^{\circ} \mathrm{C}$ for $18 \mathrm{~h}$ under $\mathrm{H}_{2}$ pressure ( $1 \mathrm{~atm}$ ). After the complete consumption of starting material as monitored by TLC $\left(R_{\mathrm{f}}\right.$ 0.4, 9:1 hexanes/ethyl acetate) and GC-MS, the reaction mixture was cooled to rt. Septum was removed and $3 \mathrm{~mL}$ EtOAc was added to the reaction mixture and mixture was stirred for a minute at rt. Stirring was stopped and organic layer was allowed to separate from aqueous layer. Organic layer was withdrawn with the aid of syringe needle. This extraction process was repeated for an additional time. Combined organic layers were dried over anhydrous sodium sulfate. Volatiles were removed under reduce pressure to obtain crude product. Crude product was further purified by flash chromatography over silica gel using $5 \%$ EtOAc/hexanes as eluent to obtain pure product, 3-(4-(benzyloxy)phenyl)-1phenylpropan-1-one (2) as white solid, yield 89.2\% (141 mg).

\section{Activity test with filtrate}

To the filtrate obtained above, freshly argon purged $1.5 \mathrm{~mL} 3 \mathrm{wt} \%$ aqueous PS-750-M was added under argon atmosphere. 1 (E)-3-(4-(benzyloxy)phenyl)-1-phenylprop-2-en-1-one (157 mg, $0.5 \mathrm{mmol}$ ) was dissolved in $0.5 \mathrm{~mL}$ dry THF and was added into the reaction mixture. The reaction mixture was evacuated and backfilled with argon for three times. Finally, the reaction mixture was carefully evacuated and backfilled with $\mathrm{H}_{2}$ using a balloon filled with hydrogen gas. The reaction mixture was stirred at $45^{\circ} \mathrm{C}$ for $18 \mathrm{~h}$ under $\mathrm{H}_{2}$ pressure $(1 \mathrm{~atm})$. After $18 \mathrm{~h}$, the reaction mixture was cooled to rt. Only traces of product were observed on TLC. 


\section{OPTIMIZATIONS}

Table S1. Amount of $\mathrm{Pd}(\mathrm{OAc})_{2}{ }^{a}$
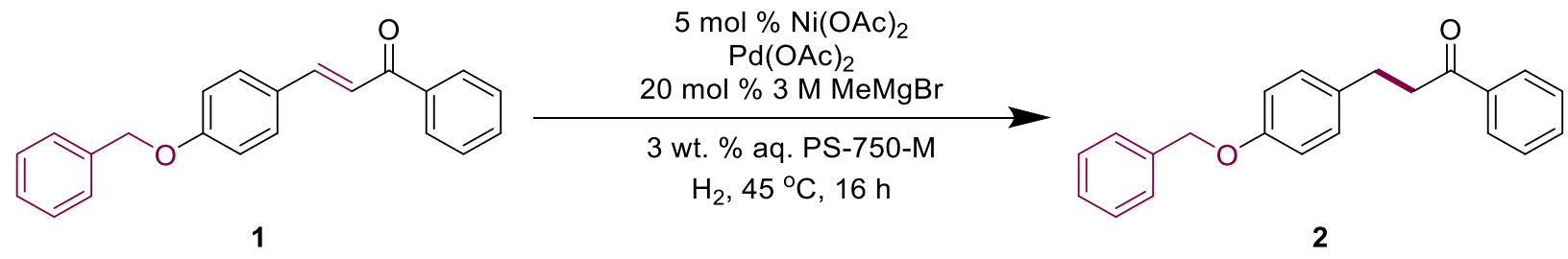

\begin{tabular}{ccc}
\hline entry & $\mathrm{Pd}(\mathrm{OAc})_{2}(\mathrm{~mol} \mathrm{\% )}$ & $\mathbf{2}(\%)^{b}$ \\
\hline 1 & 0.5 & $>99$ \\
$\mathbf{2}$ & $\mathbf{0 . 2}$ & $>\mathbf{9 9}(\mathbf{9 4})^{c}$ \\
3 & 0.1 & 88 \\
4 & 0.075 & 27 \\
5 & 0.05 & 8
\end{tabular}

${ }^{a} \mathbf{1}$ (78 mg, $\left.0.25 \mathrm{mmol}\right), \mathrm{Ni}(\mathrm{OAc})_{2}(2.2 \mathrm{mg}, 0.0125 \mathrm{mmol}), \mathrm{Pd}(\mathrm{OAc})_{2}, 3.0 \mathrm{M} \mathrm{MeMgBr}$ in diethyl ether (17 $\mu \mathrm{L}, 0.05 \mathrm{mmol}, 20 \mathrm{~mol} \%$ ), $0.75 \mathrm{~mL} 3$ wt. \% aq. PS-750-M, $0.25 \mathrm{~mL}$ THF, $\mathrm{H}_{2}$ balloon, $45{ }^{\circ} \mathrm{C}$; ${ }^{b} \mathrm{GC}-\mathrm{MS}$ analysis with conversions based on unreacted starting material; ${ }^{c}$ isolated yield.

Table S2. Amount of $\mathrm{Ni}(\mathrm{OAc})_{2}{ }^{a}$
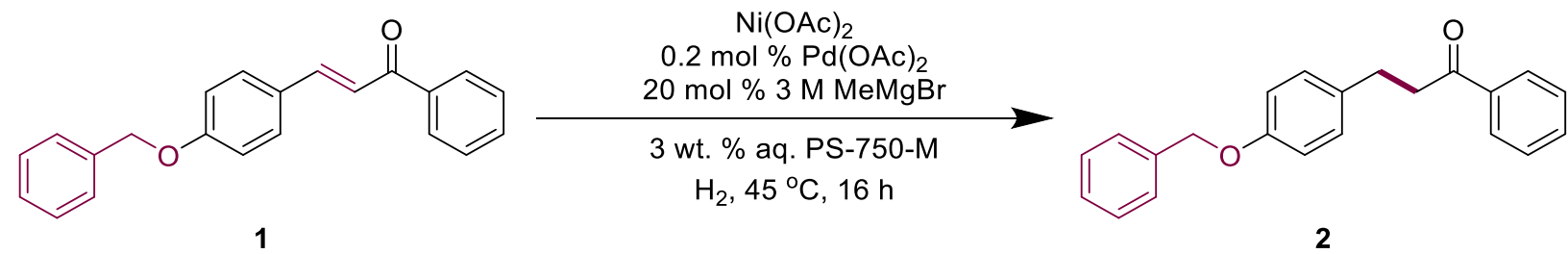

\begin{tabular}{ccc}
\hline entry & $\mathrm{Ni}(\mathrm{OAc})_{2}(\mathrm{~mol} \mathrm{\% )}$ & $\mathbf{2}(\%)^{b}$ \\
\hline 1 & 10 & $>99$ \\
2 & $\mathbf{5}$ & $>\mathbf{9 9}$ \\
3 & 3 & 52 \\
4 & 2 & 40
\end{tabular}

${ }^{a} 1$ (78 mg, $\left.0.25 \mathrm{mmol}\right), \mathrm{Ni}(\mathrm{OAc})_{2}, \mathrm{Pd}(\mathrm{OAc})_{2}(0.11 \mathrm{mg}, 0.0005 \mathrm{mmol}), 3.0 \mathrm{M} \mathrm{MeMgBr}$ in diethyl ether $(17 \mu \mathrm{L}, 0.05 \mathrm{mmol}, 20 \mathrm{~mol} \%), 0.75 \mathrm{~mL} 3$ wt. \% aq. PS-750-M, $0.25 \mathrm{~mL}$ THF, $\mathrm{H}_{2}$ balloon, $45{ }^{\circ} \mathrm{C} ;{ }^{b} \mathrm{GC}-$ MS analysis with conversions based on unreacted starting material. 
Table S3. Choice of surfactant ${ }^{a}$<smiles>O=C(/C=C/c1ccc(OCc2ccccc2)cc1)c1ccccc1</smiles>
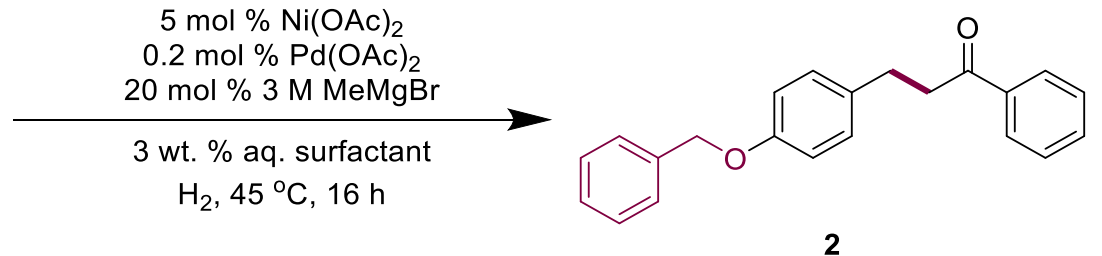

\begin{tabular}{ccc}
\hline entry & surfactant & $\mathbf{2}(\%)^{b}$ \\
\hline $\mathbf{1}$ & PS-750-M & $\mathbf{9 4}$ \\
2 & mPEG-750-M & 16 \\
3 & Neat THF & $\mathrm{NR}^{c}$ \\
4 & Proline & traces $^{c, d}$
\end{tabular}

${ }^{a} 1(78 \mathrm{mg}, 0.25 \mathrm{mmol}), \mathrm{Ni}(\mathrm{OAc})_{2}(2.2 \mathrm{mg}, 0.0125 \mathrm{mmol}), \mathrm{Pd}(\mathrm{OAc})_{2}(0.11 \mathrm{mg}, 0.0005 \mathrm{mmol}), 3.0 \mathrm{M}$ $\mathrm{MeMgBr}$ solution in ether (17 $\mu \mathrm{L}, 0.05 \mathrm{mmol}, 20 \mathrm{~mol} \%), 0.75 \mathrm{~mL} 3$ wt. \% aq. surfactant, $0.25 \mathrm{~mL}$ THF, $\mathrm{H}_{2}$ balloon, $45{ }^{\circ} \mathrm{C}$; ${ }^{b}$ isolated yields; ${ }^{c} \mathrm{GC}-\mathrm{MS}$ analysis with conversions based on unreacted starting material ${ }^{d} 18 \%$ unknown byproduct was also observed on GC-MS.; NR= no reaction.

Table S4. Optimum reaction temperature ${ }^{a}$

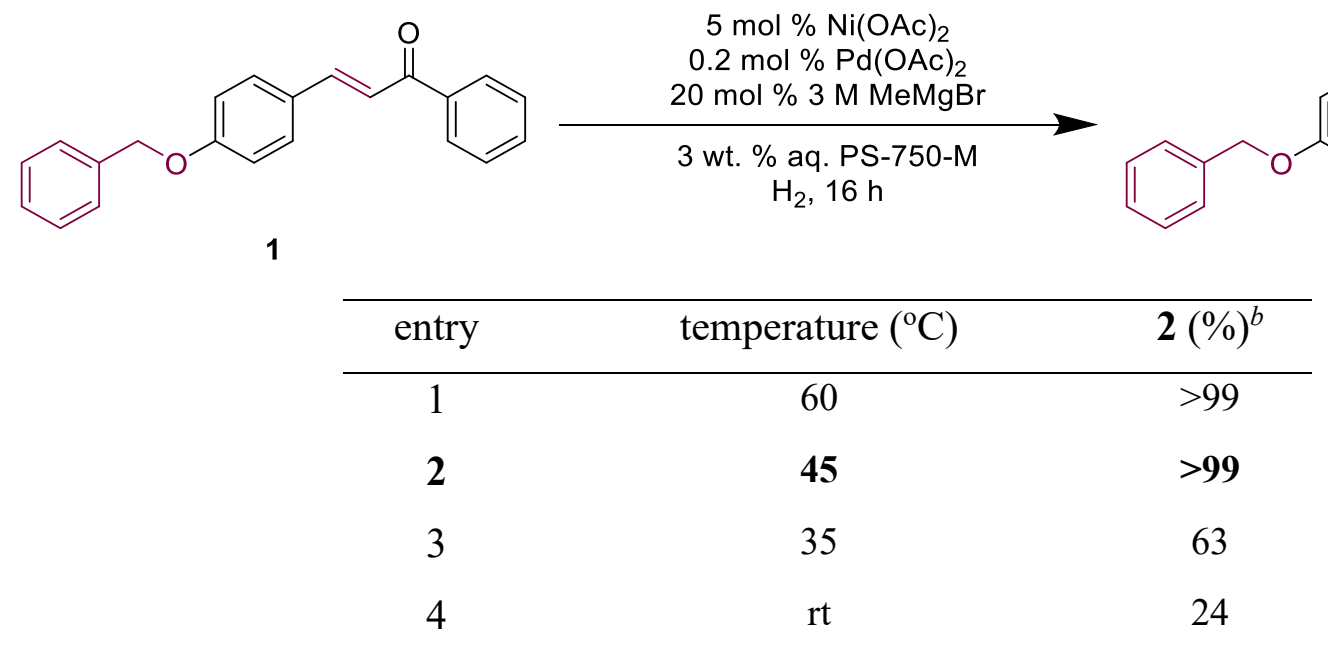

${ }^{a} \mathbf{1}(78 \mathrm{mg}, 0.25 \mathrm{mmol}), \mathrm{Ni}(\mathrm{OAc})_{2}(2.2 \mathrm{mg}, 0.0125 \mathrm{mmol}), \mathrm{Pd}(\mathrm{OAc})_{2}(0.11 \mathrm{mg}, 0.0005 \mathrm{mmol}), 3.0 \mathrm{M}$ $\mathrm{MeMgBr}$ solution in diethyl ether $(17 \mu \mathrm{L}, 0.05 \mathrm{mmol}, 20 \mathrm{~mol} \%), 0.75 \mathrm{~mL} 3$ wt. \% aq. PS-750-M, 0.25 $\mathrm{mL}$ THF, $\mathrm{H}_{2}$ balloon; ${ }^{b} \mathrm{GC}-\mathrm{MS}$ analysis with conversions based on unreacted starting material. 


\section{CONTROL EXPERIMENTS}

\subsection{No Grignard - only Ni and Pd}

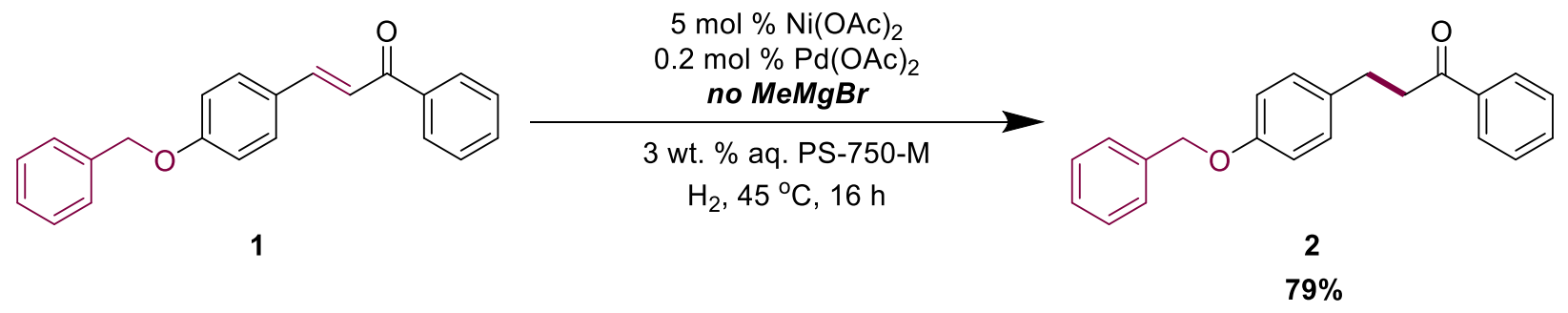

In a flame-dried $4 \mathrm{~mL}$ microwave reaction vial containing PTFE-coated stir bar, $\mathrm{Ni}(\mathrm{OAc})_{2}(2.2$ $\mathrm{mg}, 0.025 \mathrm{mmol}, 5 \mathrm{~mol} \%)$ was added under the argon atmosphere. $\mathrm{Pd}(\mathrm{OAc})_{2}(0.11 \mathrm{mg}, 0.0005$ mmol, $0.2 \mathrm{~mol} \%$, from a stock solution in THF) and $0.25 \mathrm{~mL}$ anhydrous THF were added to the reaction mixture under the argon atmosphere. Reaction mixture was heated at $60{ }^{\circ} \mathrm{C}$ for 5 minutes and then mixture was allowed to cool to rt. $0.75 \mathrm{~mL} 3.0 \mathrm{wt}$ \% aq. PS-750-M was added to the reaction mixture and mixture was stirred for 5 minutes at $\mathrm{rt.} 1$ (78 $\mathrm{mg}, 0.25 \mathrm{mmol}$ ) was added to the reaction mixture and septum was closed. Reaction mixture was evacuated and backfilled with hydrogen gas by introducing hydrogen balloon on the top of septum. Reaction mixture was stirred under hydrogen atmosphere at $45^{\circ} \mathrm{C}$.

After $16 \mathrm{~h}, 0.5 \mathrm{~mL}$ EtOAc was added to the reaction mixture, and it was stirred for a minute. Organic layer was separated with the help of syringe. EtOAc was added one more time and an aliquot (20-25 $\mu \mathrm{L})$ was passed through a very small silica plug and then analyzed by GC-MS. GC-MS analysis based on unreacted starting material showed $79 \%$ conversion to the desired product and $22 \%$ conversion to an unknown byproduct.

\subsection{No Pd(OAc)2 - only Ni NPs}

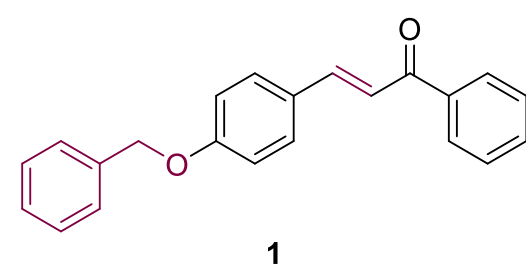

1

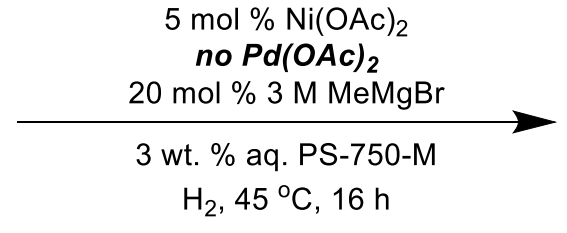

$\mathrm{H}_{2}, 45^{\circ} \mathrm{C}, 16 \mathrm{~h}$

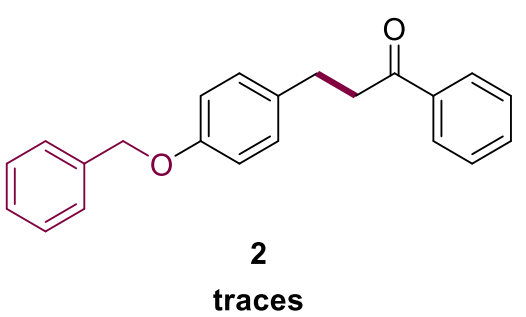

In a flame-dried $4 \mathrm{~mL}$ microwave reaction vial containing PTFE-coated stir bar, $\mathrm{Ni}(\mathrm{OAc})_{2}(2.2$ $\mathrm{mg}, 0.025 \mathrm{mmol}, 5 \mathrm{~mol} \%$ ) was added under the argon atmosphere. $0.25 \mathrm{~mL}$ anhydrous THF was 
added to the reaction mixture under the argon atmosphere. Reaction mixture was heated at $60{ }^{\circ} \mathrm{C}$ for 5 minutes and then mixture was allowed to cool to rt. 3.0 M MeMgBr solution in ether (17 $\mu \mathrm{L}, 0.05 \mathrm{mmol}, 20 \mathrm{~mol} \%$ ) was added to the reaction mixture. Reaction mixture was stirred for 5 minutes at rt. $0.75 \mathrm{~mL} 3.0$ wt. \% aq. PS-750-M was added to the reaction mixture and mixture was stirred for 5 minutes at rt. $1(78 \mathrm{mg}, 0.25 \mathrm{mmol})$ was added to the reaction mixture and septum was closed. Reaction mixture was evacuated and backfilled with hydrogen gas by introducing hydrogen balloon on the top of septum. Reaction mixture was stirred under hydrogen atmosphere at $45^{\circ} \mathrm{C}$.

After $16 \mathrm{~h}, 0.5 \mathrm{~mL}$ EtOAc was added to the reaction mixture, and it was stirred for a minute. Organic layer was separated with the help of syringe. EtOAc was added one more time and an aliquot $(20-25 \mu \mathrm{L})$ was passed through a very small silica plug and then analyzed by GC-MS. GC-MS analysis showed only traces of the desired product.

\subsection{No Ni(OAc) $)_{2}$ - only Pd NPs}

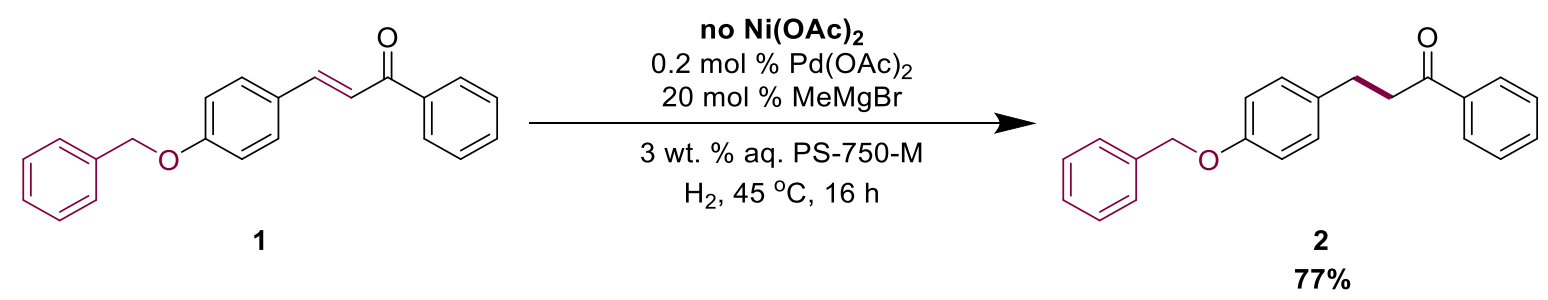

In a flame-dried $4 \mathrm{~mL}$ microwave reaction vial containing PTFE-coated stir bar, $\mathrm{Pd}(\mathrm{OAc})_{2}(0.11$ $\mathrm{mg}, 0.0005 \mathrm{mmol}, 0.2 \mathrm{~mol} \%$, from a stock solution in THF) and $0.25 \mathrm{~mL}$ anhydrous THF were added to the reaction mixture under the argon atmosphere. Reaction mixture was heated at $60{ }^{\circ} \mathrm{C}$ for 5 minutes and then mixture was allowed to cool to rt. 3.0 M MeMgBr solution in diethyl ether (17 $\mu \mathrm{L}, 0.05 \mathrm{mmol}, 20 \mathrm{~mol} \%)$ was added to the reaction mixture. Reaction mixture was stirred for 5 minutes at rt. Afterwards, $0.75 \mathrm{~mL} 3.0 \mathrm{wt}$ \% aq. PS-750-M was added to the reaction mixture and mixture was stirred for 5 minutes at $\mathrm{rt.} 1$ (78 $\mathrm{mg}, 0.25 \mathrm{mmol})$ was added to the reaction mixture and septum was closed. Reaction mixture was evacuated and backfilled with hydrogen gas by introducing hydrogen balloon on the top of septum. Reaction mixture was stirred under hydrogen atmosphere at $45{ }^{\circ} \mathrm{C}$.

After $16 \mathrm{~h}, 0.5 \mathrm{~mL}$ EtOAc was added to the reaction mixture, and it was stirred for a minute. Organic layer was separated with the help of syringe. EtOAc was added one more time and an aliquot $(20-25 \mu \mathrm{L})$ was passed through a very small silica plug and then analyzed by GC-MS. 
GC-MS analysis based on unreacted starting material showed $77 \%$ conversion to the desired product with $17 \%$ conversion to an unknown byproduct.

\subsection{Direct comparison of Ni/Pd NPs catalyzed hydrogenation: "on water" versus "in water" using aqueous PS-750-M}

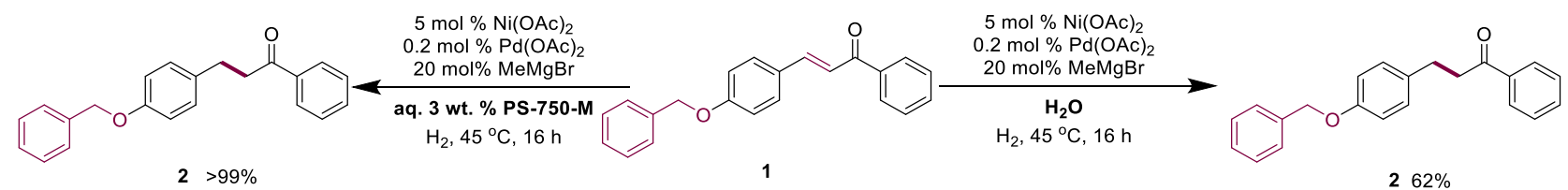

In a flame-dried $4 \mathrm{~mL}$ microwave reaction vial containing PTFE-coated stir bar, $\mathrm{Ni}(\mathrm{OAc})_{2}(2.2$ $\mathrm{mg}, 0.025 \mathrm{mmol}, 5 \mathrm{~mol} \%)$ was added under the argon atmosphere. $\mathrm{Pd}(\mathrm{OAc})_{2}(0.11 \mathrm{mg}, 0.0005$ mmol, $0.2 \mathrm{~mol} \%$, from a stock solution in THF) and $0.25 \mathrm{~mL}$ anhydrous THF were added to the reaction mixture under the argon atmosphere. Reaction mixture was heated at $60{ }^{\circ} \mathrm{C}$ for 5 minutes and then mixture was allowed to cool to rt. 3.0 M MeMgBr solution in diethyl ether (17 $\mu \mathrm{L}, 0.05 \mathrm{mmol}, 20 \mathrm{~mol} \%$ ) was added to the reaction mixture. Reaction mixture was stirred for 5 minutes at rt. $0.75 \mathrm{~mL}$ HPLC grade water was added to the reaction mixture and mixture was stirred for 5 minutes at $\mathrm{rt} .1$ (78 $\mathrm{mg}, 0.25 \mathrm{mmol})$ was added to the reaction mixture and septum was closed. Reaction mixture was evacuated and backfilled with hydrogen gas by introducing hydrogen balloon on the top of septum. Reaction mixture was stirred under hydrogen atmosphere at $45^{\circ} \mathrm{C}$.

After $16 \mathrm{~h}, 0.5 \mathrm{~mL}$ EtOAc was added to the reaction mixture, and it was stirred for a minute. Organic layer was separated with the help of syringe. EtOAc was added one more time and an aliquot $(20-25 \mu \mathrm{L})$ was passed through a very small silica plug and then analyzed by GC-MS. GC-MS analysis based on unreacted starting material showed $62 \%$ conversion to product 2 and $13 \%$ conversion to an unknown byproduct. 


\section{OPTMIZED CATALYTIC REACTION PROCEDURE}

In a flame-dried $4 \mathrm{~mL}$ microwave reaction vial containing PTFE-coated stir bar, $\mathrm{Ni}(\mathrm{OAc})_{2}(4.4$ $\mathrm{mg}, 0.025 \mathrm{mmol}, 5 \mathrm{~mol} \%)$ was added under the argon atmosphere. $\mathrm{Pd}(\mathrm{OAc})_{2}(0.22 \mathrm{mg}, 0.001$ mmol, $0.2 \mathrm{~mol} \%$, from a stock solution in THF) and $0.5 \mathrm{~mL}$ anhydrous THF were added to the reaction mixture under the argon atmosphere. Reaction mixture was heated at $60{ }^{\circ} \mathrm{C}$ for 5 minutes and then mixture was allowed to cool to rt. 3.0 M MeMgBr solution in ether (33 $\mu \mathrm{L}, 0.1$ mmol, $20 \mathrm{~mol} \%$ ) was added to the reaction mixture. Upon addition of Grignard reagent, mixture turned to black color. Reaction mixture was stirred for 5 minutes at rt. $1.5 \mathrm{~mL} 3.0 \mathrm{wt}$. \% aq. PS750-M was added to the reaction mixture and mixture was stirred for 5 minutes at rt. Substrate $(0.5 \mathrm{mmol})$ was added to the reaction mixture and septum was closed. Reaction mixture was evacuated and backfilled with hydrogen gas by introducing hydrogen balloon on the top of septum. Reaction mixture was stirred under hydrogen atmosphere at $45{ }^{\circ} \mathrm{C}$ until complete consumption of starting material.

After complete consumption of starting material as monitored by TLC or GC-MS, reaction mixture was allowed to cool at $\mathrm{rt} .1 \mathrm{~mL}$ EtOAc was added to the reaction mixture, and it was stirred for a minute. Organic layer was separated with the help of syringe. If desired product is remaining in the aqueous mixture, same extraction procedure was repeated. Organic layer was dried over anhydrous sodium sulfate. Volatiles were evacuated to obtain crude product, which was further purified by flash column chromatography using EtOAc/hexanes. 


\section{SUBSTRATE SCOPE}

Table S7. Substrate scope for selective reduction of enones ${ }^{a}$
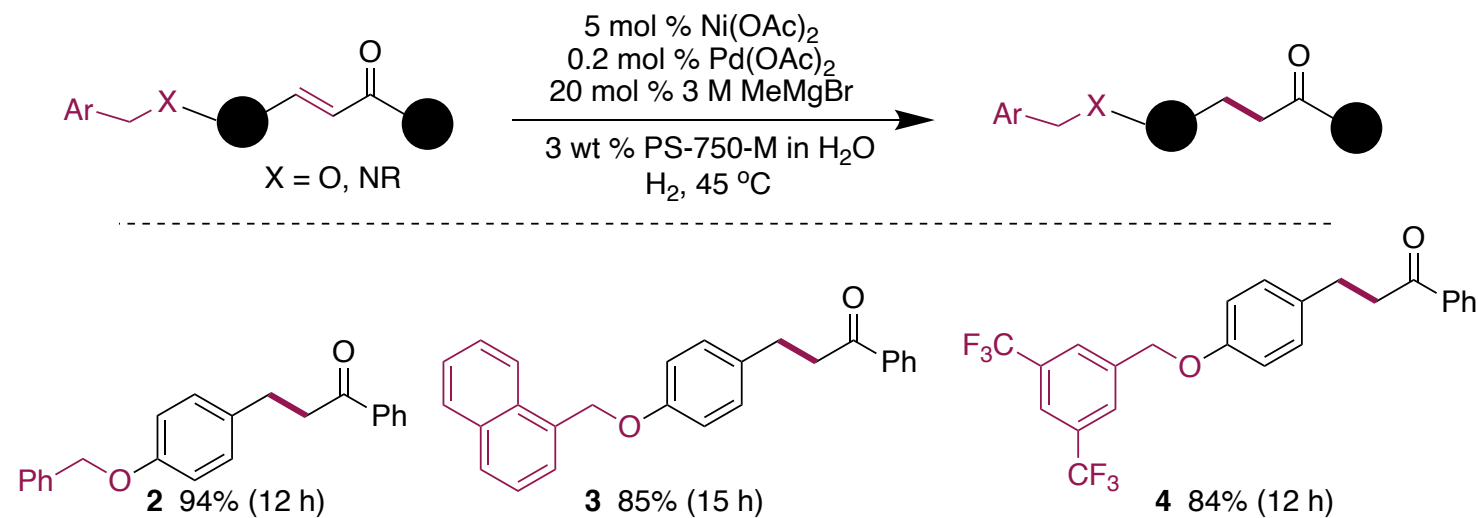<smiles>COc1cc(C(=O)OCc2ccc(CCC(=O)c3ccccc3)cc2)ccc1COc1ccc(CCC(=O)c2ccc(CCC(=O)c3ccccc3)cc2)cc1</smiles><smiles>C=c1c(=C(C)c2ccc(COc3ccc(CCC(=O)c4ccccc4)cc3)cc2)ccc2cccc(C)c12</smiles><smiles>CC=C(/C=C\C)/C=C\C(=O)Oc1ccc(CCC(=O)c2ccc(CCC(=O)c3ccc(-c4ccccc4OC)cc3)cc2)cc1</smiles>

${ }^{a}$ Conditions: (i) $\mathrm{Ni}(\mathrm{OAc})_{2}(5 \mathrm{~mol} \%), \mathrm{Pd}(\mathrm{OAc})_{2}(0.2 \mathrm{~mol} \%)$, THF $(0.5 \mathrm{~mL}), 60{ }^{\circ} \mathrm{C}, 5 \mathrm{~min}$; (ii) $3 \mathrm{M}$ $\mathrm{MeMgBr}(20 \mathrm{~mol} \%)$, rt, $5 \mathrm{~min}$; (iii) $3 \mathrm{wt} \%$ aq. PS-750-M (1.5 mL), enone (0.5 mmol), $\mathrm{H}_{2}, 45^{\circ} \mathrm{C}$. All yields are isolated; ${ }^{*} 0.25 \mathrm{mmol}$ scale reaction. 
Table S8. Activity test on enones containing no $N$ - or $O$-benzyl groups ${ }^{a}$

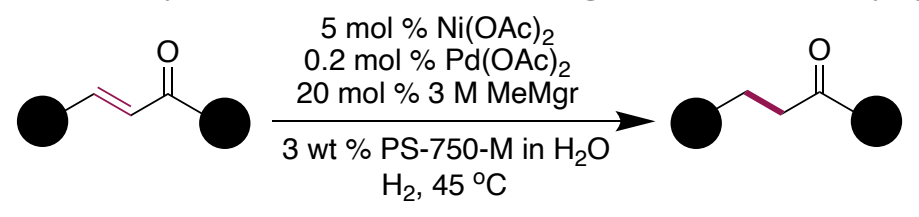<smiles>O=C(CCc1ccco1)c1ccccc1</smiles>

$1890 \%(13 \mathrm{~h})$<smiles>O=C(CCc1ccsc1)c1ccccc1</smiles>

$1995 \%(36 \mathrm{~h})$<smiles>O=C(CCc1ccc2[nH]ccc2c1)c1ccccc1</smiles>

$2092 \%(14 \mathrm{~h})$<smiles>O=C(CCc1ccc(OS(=O)(=O)O[18O]c2ccccc2)cc1)CCc1ccc(OS(=O)(=O)c2ccccc2)cc1</smiles>

$2182 \%(14 \mathrm{~h})$

$2288 \%(18 \mathrm{~h})$

$2390 \%(18 \mathrm{~h})$<smiles>O=C(CCc1ccccc1)c1ccccc1</smiles><smiles>O=C1/C(=C/c2ccccc2)CCC1Cc1ccccc1</smiles>

$2488 \%(12 h)$

$2556 \%(12 \mathrm{~h})$<smiles>Cc1nn(C)c(C)c1S(=O)(=O)Oc1ccc(CCC(=O)c2ccccc2)cc1</smiles>

${ }^{a}$ Conditions: (i) $\mathrm{Ni}(\mathrm{OAc})_{2}(5 \mathrm{~mol} \%), \mathrm{Pd}(\mathrm{OAc})_{2}(0.2 \mathrm{~mol} \%)$, THF $(0.5 \mathrm{~mL}), 60{ }^{\circ} \mathrm{C}, 5 \mathrm{~min}$; (ii) $3 \mathrm{M} \mathrm{MeMgBr}(20$ mol \%), rt, $5 \mathrm{~min}$; (iii) $3 \mathrm{wt} \%$ aq. PS-750-M $(1.5 \mathrm{~mL})$, enone $(0.5 \mathrm{mmol}), \mathrm{H}_{2}, 45^{\circ} \mathrm{C}$. All yields are isolated; ${ }^{*} 0.25$ mmol scale reaction.

Table S9. Selective reduction of enenitrile, enamide, and $\alpha$-ketoamide ${ }^{a}$
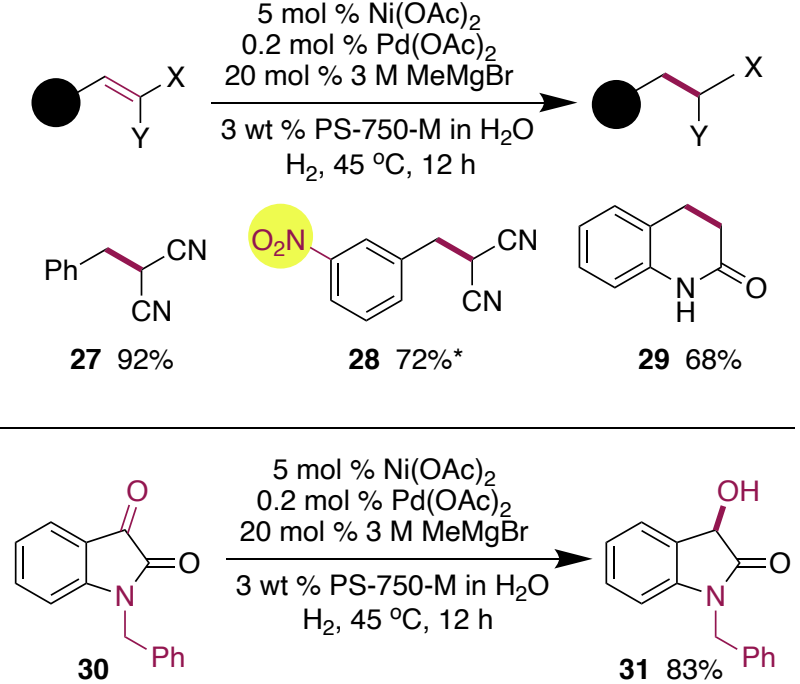

${ }^{a}$ Conditions: (i) $\mathrm{Ni}(\mathrm{OAc})_{2}(5 \mathrm{~mol} \%), \mathrm{Pd}(\mathrm{OAc})_{2}(0.2 \mathrm{~mol} \%)$, THF $(0.5 \mathrm{~mL}), 60{ }^{\circ} \mathrm{C}, 5 \mathrm{~min}$; (ii) $3 \mathrm{M} \mathrm{MeMgBr}$ (20 mol \%), rt, $5 \mathrm{~min}$; (iii) $3 \mathrm{wt} \%$ aq. PS-750-M $(1.5 \mathrm{~mL})$, substrate $(0.5 \mathrm{mmol}), \mathrm{H}_{2}, 45{ }^{\circ} \mathrm{C}$. All yields are isolated. $* 0.4 \mathrm{~mol} \% \mathrm{Pd}(\mathrm{OAc})_{2}$ was used in the catalyst for this example; except $72 \%$ isolated desired product, $c a$. $10 \%$ byproduct from hydrolysis of enenitrile was observed; no nitro reduction was observed 


\section{GRAM-SCALE REACTION}

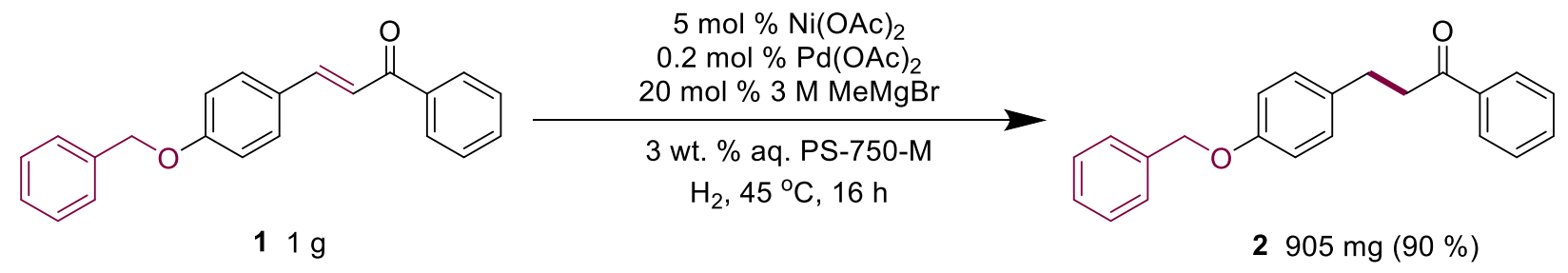

In a flame-dried $50 \mathrm{~mL}$ round-bottom flask containing PTFE-coated stir bar, $\mathrm{Ni}(\mathrm{OAc})_{2}(28 \mathrm{mg}$, $0.16 \mathrm{mmol}, 5 \mathrm{~mol} \%)$ was added under the argon atmosphere. $\mathrm{Pd}(\mathrm{OAc})_{2}(1.4 \mathrm{mg}, 0.0064 \mathrm{mmol}$, $0.2 \mathrm{~mol} \%$ ) and $3 \mathrm{~mL}$ anhydrous THF were added to the reaction mixture under the argon atmosphere. Reaction mixture was heated at $60{ }^{\circ} \mathrm{C}$ for 5 minutes and then mixture was allowed to cool to rt. 3.0 M MeMgBr solution in diethyl ether $(0.22 \mathrm{~mL}, 0.64 \mathrm{mmol}, 20 \mathrm{~mol} \%)$ was added to the reaction mixture. Upon addition of Grignard reagent, mixture turned to black color. Reaction mixture was stirred for 5 minutes at rt. $10 \mathrm{~mL} 3.0 \mathrm{wt}$ \% aq. PS-750-M was added to the reaction mixture and mixture was stirred for 5 minutes at rt. Chalcone 1 ( $1 \mathrm{~g}, 3.18 \mathrm{mmol})$ was added to the reaction mixture and septum was closed. Reaction mixture was evacuated and backfilled with hydrogen gas by introducing hydrogen balloon on the top of septum. Reaction mixture was stirred under hydrogen atmosphere at $45{ }^{\circ} \mathrm{C}$ until complete consumption of starting material.

After complete consumption of starting material as monitored by TLC or GCMS, reaction mixture was allowed to cool at rt. $5 \mathrm{~mL}$ EtOAc was added to the reaction mixture, and it was stirred for a minute. Organic layer was separated with the help of syringe. Same extraction procedure was repeated one more time. Organic layer was dried over anhydrous sodium sulfate. Volatiles were evacuated to obtain crude product, which was further purified by flash chromatography using EtOAc/hexanes (0-25\%) to achieve 2 as viscous oil (905 mg, 90 \%). 


\section{DETAILED ANALYSIS OF NANOPARTICLES}

\subsection{HRTEM and STEM analysis of nanoparticles}

Scanning TEM (STEM) and High-Resolution TEM (HRTEM) imaging of the material was carried out to determine the elemental composition of the nanomaterial.
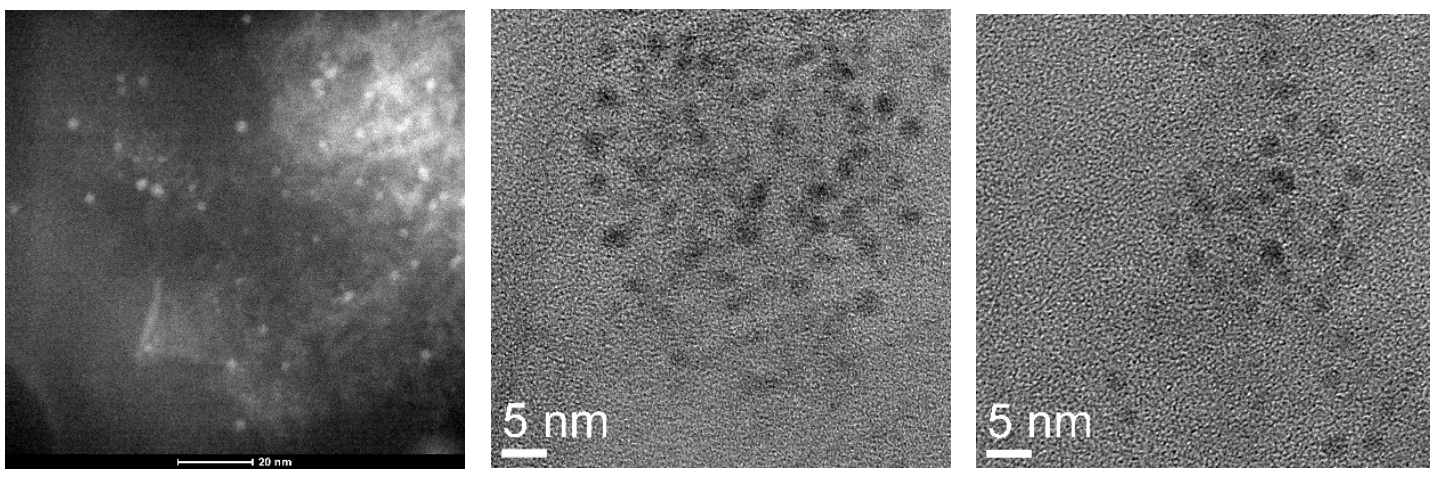

Figure S2. STEM and HRTEM of nanoparticles

FEI Tecnai F20 with $200 \mathrm{kV}$ field emission gun was used for the HRTEM and STEM analysis. The images show the nanoparticles are small and spherically shaped (Figure S2).

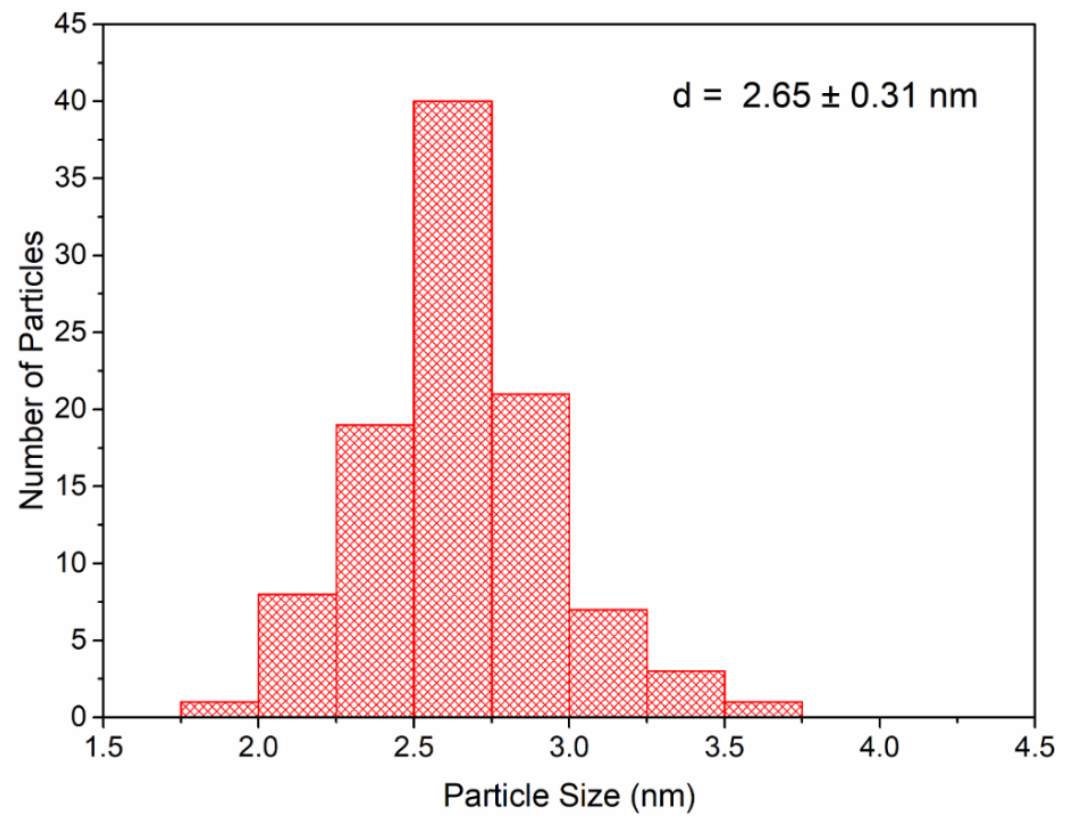

Figure S3. Plot of particle size distribution from HRTEM 


\subsection{EDAX analysis of nanoparticles}

EDAX analysis and mapping was done to observe the elemental distribution of the nanoparticles

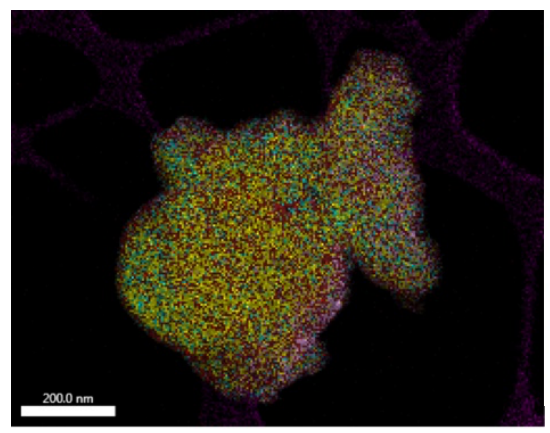

$51 \%$ C K

$12 \%$ O K

$17 \% \mathrm{MgK}$

$1 \% \mathrm{PdL}$

$6 \%$ NiK

$13 \%$ BrK

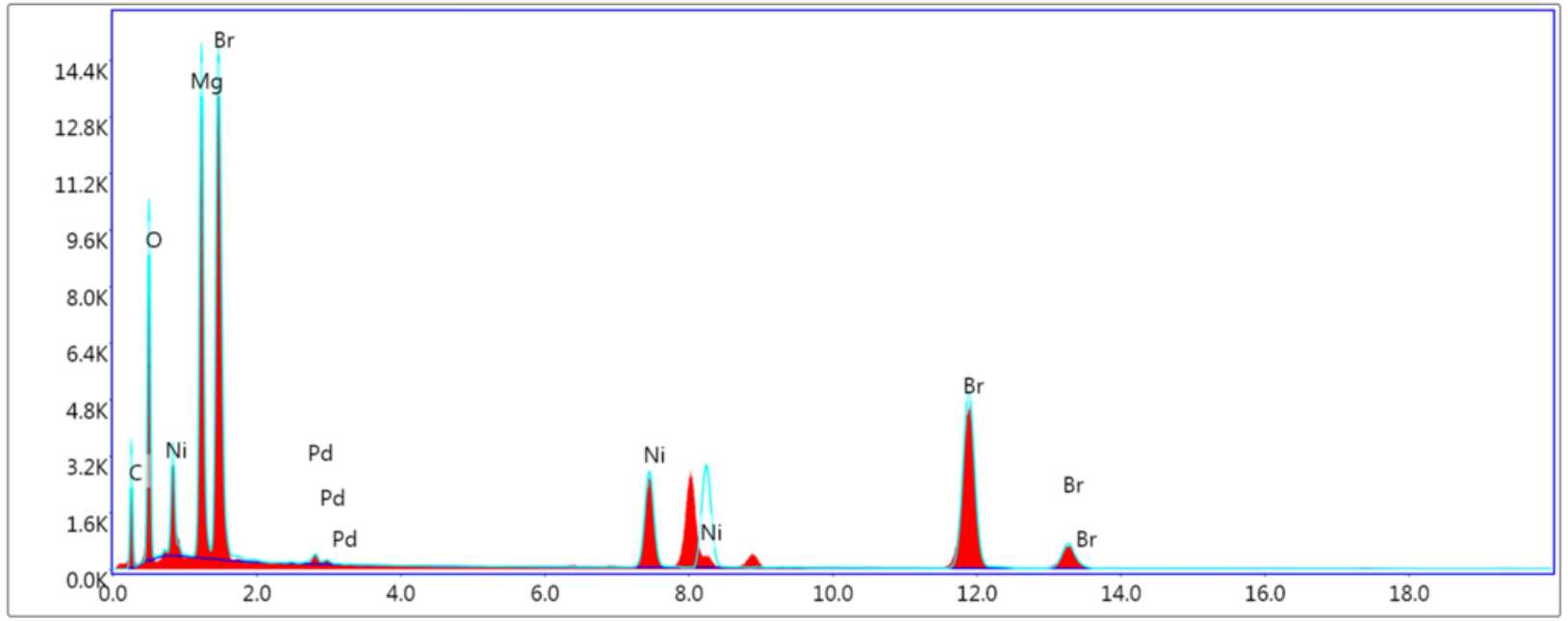

Figure S4. EDAX mapping of active nanoparticles

Table S10. Quantification data obtained from EDAX

\begin{tabular}{ccccc}
\hline Element & Weight $\%$ & Atomic $\%$ & Net Int. & Error \% \\
\hline C K & 13.01 & 18.92 & 36.3 & 9.24 \\
O K & 51.36 & 56.07 & 466.5 & 7.06 \\
MgK & 34.45 & 24.75 & 907.7 & 7.56 \\
PdL & 0.52 & 0.08 & 23.5 & 13.63 \\
NiK & 0.38 & 0.11 & 395.7 & 9.94 \\
BrK & 0.28 & 0.06 & 932.2 & 34.32 \\
\hline
\end{tabular}




\subsection{XPS analysis of nanoparticles}

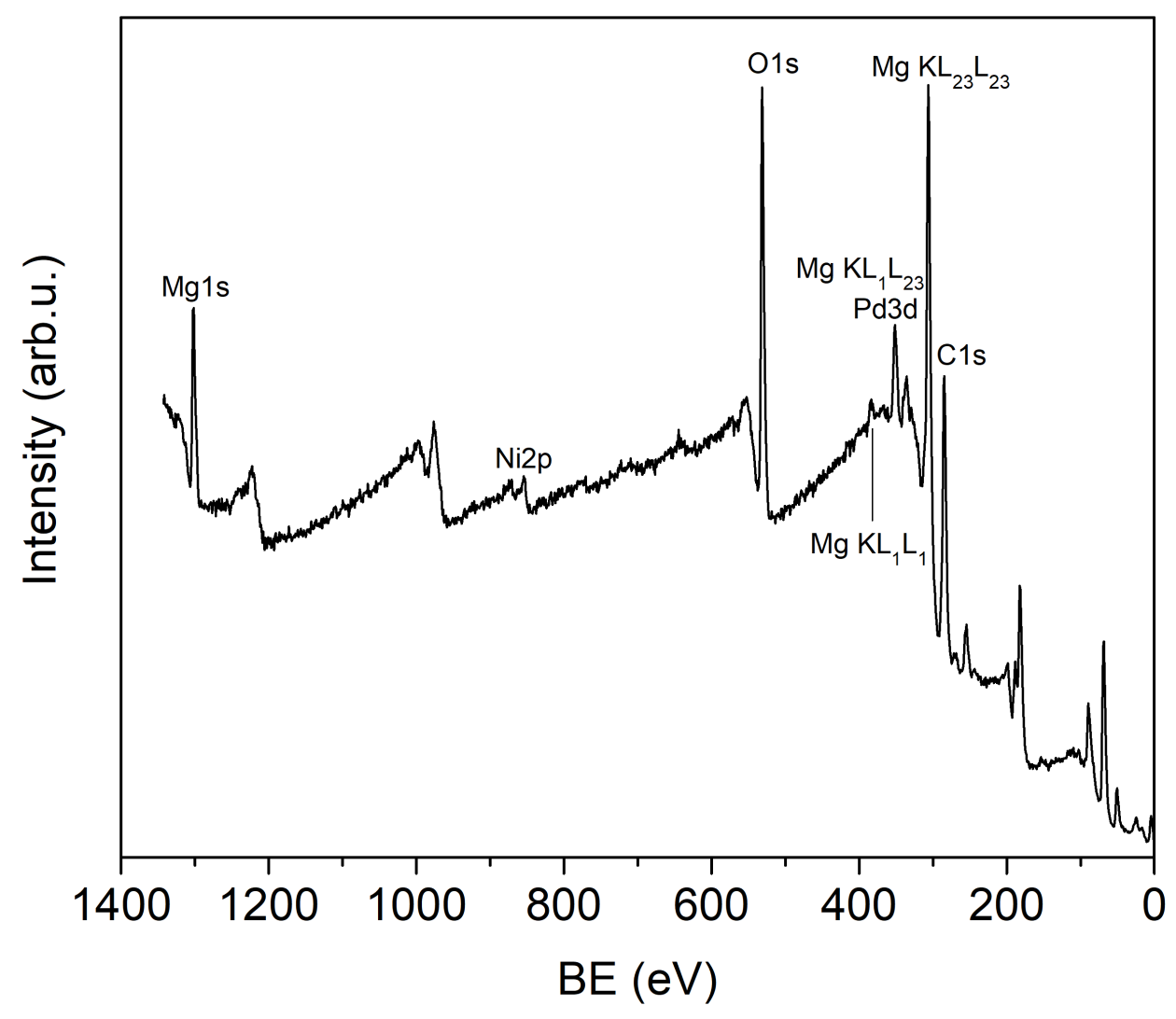

Figure S5. XPS analysis: A survey spectrum.

X-ray photoelectron spectroscopy (XPS) spectra were collected, at an electron emission angle of $54.7^{\circ}$ relative to the surface normal, using a VG Scientific MultiLab 3000 ultra-high vacuum surface analysis system, operating at the base pressure in the $10^{-9}$ Torr range and equipped with dual-anode $(\mathrm{Mg} / \mathrm{Al}) \mathrm{X}$-ray source and CLAM4 hemispherical electron energy analyzer. A non-monochromatized Al K $\alpha$ X-ray beam ( $\mathrm{h} v \approx 1486.6 \mathrm{eV})$ was used as the source. A low-resolution survey spectrum was measured between 1400 to $0 \mathrm{eV}$ using the pass energy of $100 \mathrm{eV}$ to identify all elements. In addition, high-resolution spectra of C1s, Pd3d, Ni2p, and O1s were collected at the pass energy of $20 \mathrm{eV}$, for the detailed binding energy (BE) analysis. The adventitious $\mathrm{C} 1 \mathrm{~s}, \mathrm{C}-\mathrm{C}$ peak at $284.5 \mathrm{eV}$, was used for the BE calibration. 
The survey spectrum confirmed the presence of $\mathrm{Mg}, \mathrm{Ni}, \mathrm{O}, \mathrm{Pd}, \mathrm{C}$ (Fig. S5). The peak deconvolution of the $\operatorname{Pd} 3 \mathrm{~d}$ region yielded a strong $\mathrm{MgKL}_{1} \mathrm{~L}_{23}$ and much weaker $\operatorname{Pd}(0)$ doublet peak, with its $\mathrm{Pd} 3 \mathrm{~d}_{5 / 2}$ component at the $\mathrm{BE}$ of $334.7 \mathrm{eV}$. The deconvolution of Ni2p spectrum revealed the $\mathrm{Ni}(0)$ at $851.7 \mathrm{eV}$. Notably, the catalyst was air-sensitive and due to air exposure, $\mathrm{Ni}$ (II) was also observed in the analyte. $\mathrm{Ni}(\mathrm{II})$ doublet line with its $\mathrm{Ni} 2 \mathrm{p}_{3 / 2}$ component at 856.6 $\mathrm{eV}$ and the $\mathrm{Ni}(\mathrm{II})$ satellite doublet line with its $\mathrm{Ni} 2 \mathrm{p}_{3 / 2}$ component at $858.4 \mathrm{eV}$ were detected. The deconvolution of the O1s peak produced one strong line at $531.5 \mathrm{eV}$ and two weaker ones, at 530.0 and $533.1 \mathrm{eV}$, respectively. The peak analysis of the $\mathrm{C} 1 \mathrm{~s}$ spectrum, yielded a strong line at $284.5 \mathrm{eV}$ and two weaker lines at 282.8 and $285.8 \mathrm{eV}$, respectively. XPS data was also used for the surface composition analysis. The obtained elemental quantification results are shown in Table 8 .

Table S11. XPS quantification

\begin{tabular}{ccccc}
\hline Element & Line & ASF & Intensity & atm\% \\
\hline $\mathrm{Pd}$ & $3 \mathrm{~d}$ & 4.6 & 113705 & 1.1 \\
$\mathrm{Ni}$ & $2 \mathrm{p}$ & 4.5 & 169414 & 1.6 \\
$\mathrm{O}$ & $1 \mathrm{~s}$ & 0.66 & 496106 & 32.6 \\
$\mathrm{C}$ & $1 \mathrm{~s}$ & 0.25 & 357884 & 62.2 \\
$\mathrm{Mg}$ & $1 \mathrm{~s}$ & 3.5 & 219417 & 2.7 \\
\hline
\end{tabular}

Note: the Pd signal is very weak in both, EDS and XPS spectra. Therefore, the Ni:Pd ratio is subject to a high error. Besides, in the XPS spectrum, the Pd3d signal overlaps with the Mg KLL, so Pd concentration has an additional uncertainty. The data only confirms the presence of $\mathrm{Ni}(0)$ and $\mathrm{Pd}(0)$, not their ratio. 


\subsection{TGA Analysis}

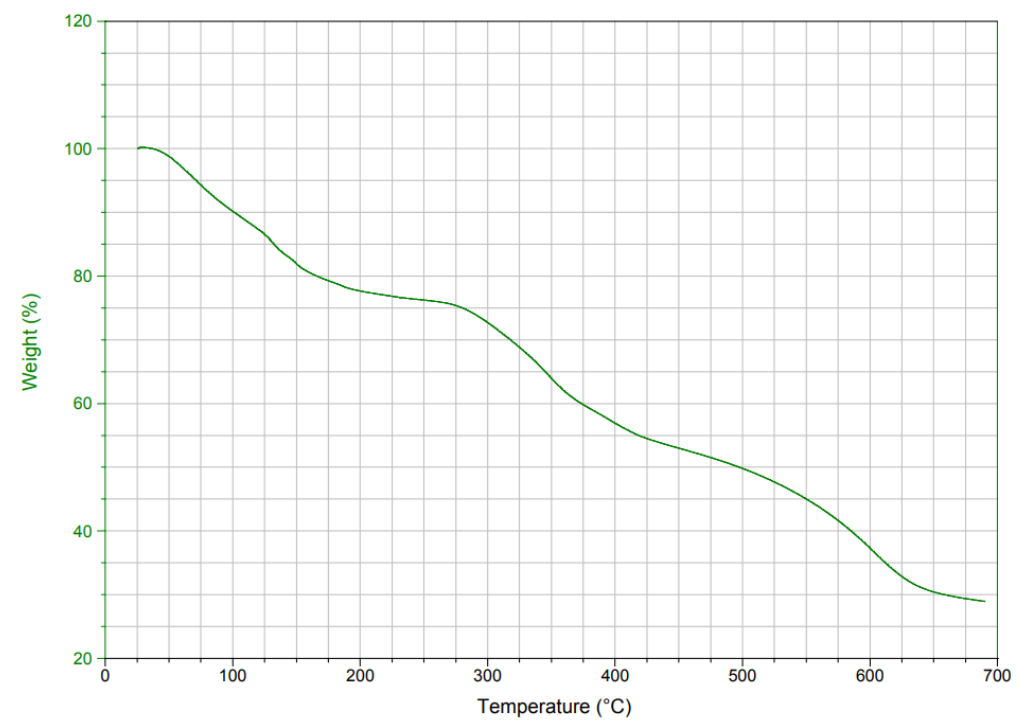

Figure S6. Thermogravimetric analysis (TGA) of NPs

\subsection{Optical Microscopy}
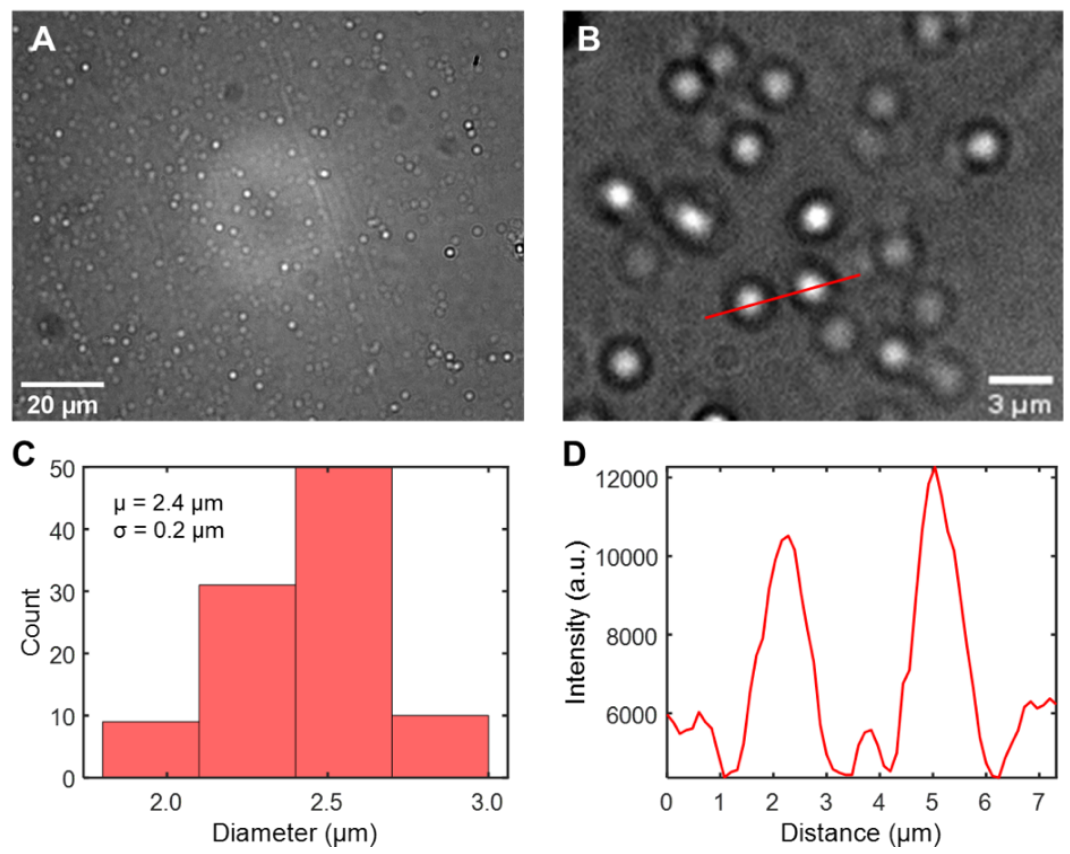

Figure S7. Optical microscopy of Ni/Pd nanoparticles capped by PS-750-M. (A) Representative optical image and (B) zoomed in representative optical image. (C) Distribution of the diameters of 100 vesicles. (D) Line profile across two micelles corresponding to the red line in panel C. Panels A-C are the same as shown in Figure 3 of the main text. 
The PS-750-M capped Ni/Pd nanoparticles were characterized by optical microscopy. An aliquot of an aqueous dispersion of PS-750-M capped Ni/Pd nanoparticles was drop-cast onto a No. 1 glass cover slip (VWR micro cover glass) and dried with a stream of $\mathrm{N}_{2}$. The sample was then mounted in an Olympus IX73 inverted optical microscope. Optical images were acquired in transmission mode using a $100 \times$ oil immersion microscope objective and a ProEM HS EM-CCD camera (Teledyne Princeton Instruments). The acquisition time for the optical images was $0.2 \mathrm{~s}$. Image analysis was performed in ImageJ. Figure S7A and S7B show representative optical images of the PS-750-M capped Ni/Pd nanoparticles. Measurement of 100 vesicles shows they have an average diameter of $2.4 \pm 0.2 \mu \mathrm{m}$ (Figure S7C, S7D) An average vesicle diameter of 2.4 $\mu \mathrm{m}$ indicates that there are many $\mathrm{Ni} / \mathrm{Pd}$ nanoparticles $(\mathrm{D}=2.65 \mathrm{~nm})$ in each individual micelle. It should also be noted that additional optical images (Figure S8) show aggregation of individual vesicles which may occur in suspension and/or during the drying process.
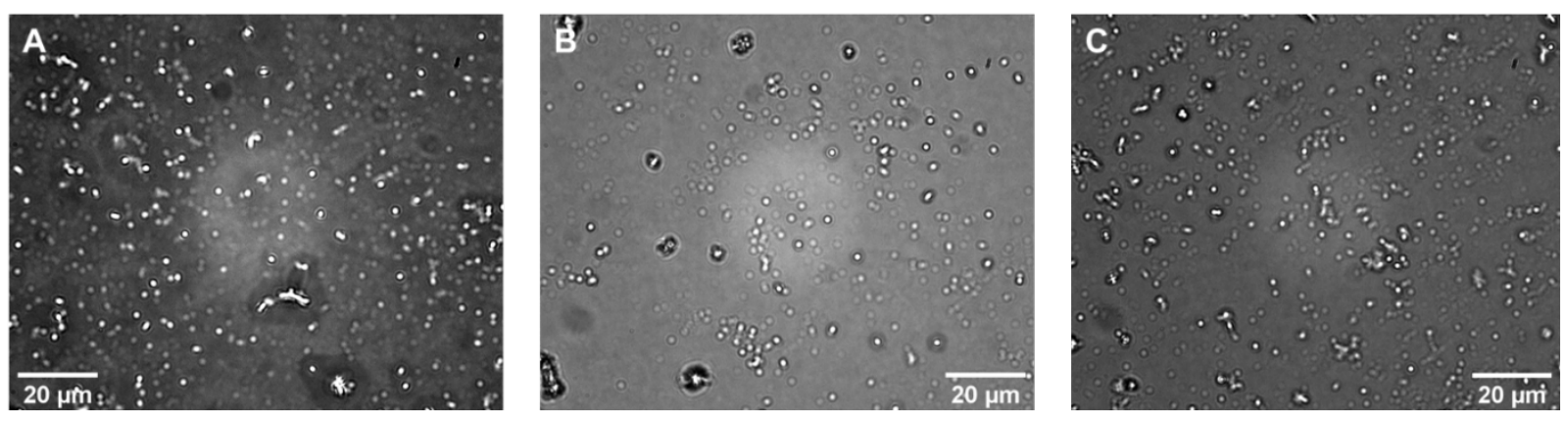

Figure S8. Additional optical images of PS-750-M capped Ni/Pd nanoparticles. 


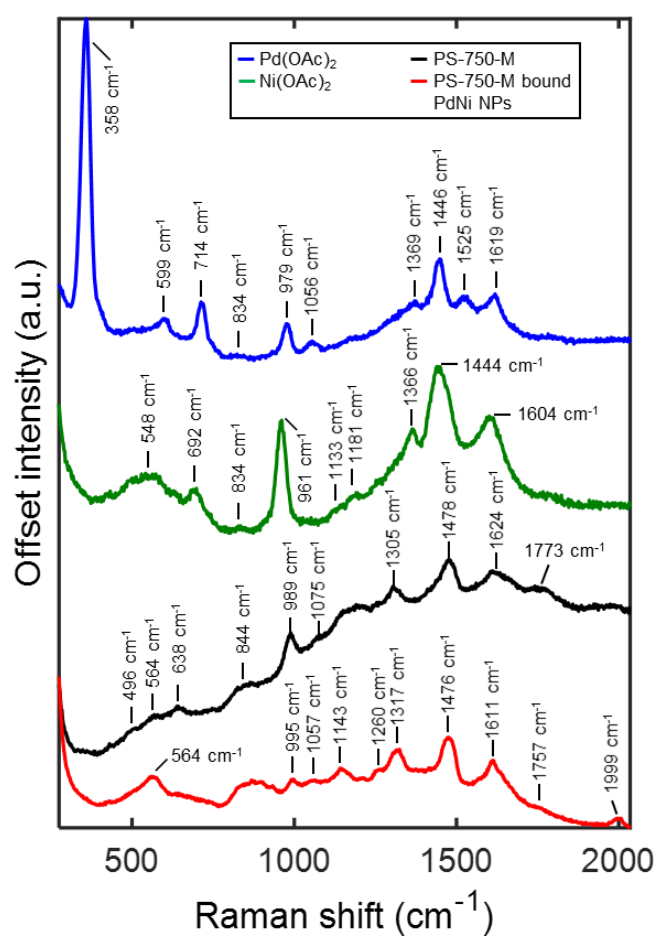

Figure S9. Raman and SERS spectra of the PS-750-M capped Ni/Pd nanoparticle catalysts and the individual components that make up the catalysts. Raman spectra of $\mathrm{Pd}(\mathrm{OAc})_{2}$ and $\mathrm{Ni}(\mathrm{OAc})_{2}$ precursor salt crystals are shown by the blue and green curves, respectively. SERS spectra of PS-750-M with and without $\mathrm{Ni} / \mathrm{Pd}$ nanoparticles are shown by the red and black curves, respectively. All samples were mounted on a roughened $\mathrm{Ag}$ electrode and spectra were acquired with $532 \mathrm{~nm}$ laser excitation. This figure is the same as Figure 2 in the main text with additional labels for the vibrational modes.

Raman and SERS substrates were prepared as previously described. ${ }^{2}$ Briefly, a Ag disc electrode was mechanically polished to a mirror finish in aqueous slurries of alumina particles (D $=0.3,0.05 \mu \mathrm{m})$ and then sonicated in DI water for $30 \mathrm{~s}$. The smooth Ag electrode surface was roughened electrochemically by cycling an applied potential between -0.3 and $0.25 \mathrm{~V}$ for three cycles at a scan rate of $5 \mathrm{mV} / \mathrm{s}$. The electrolyte used for roughening was $0.1 \mathrm{M} \mathrm{KCl}$. The final step in the preparation of the substrate was to remove surface $\mathrm{Cl}$ by applying potentials of $-0.6 \mathrm{~V}$ for $120 \mathrm{~s}, 0.55 \mathrm{~V}$ for $3 \mathrm{~s}$, and $-0.4 \mathrm{~V}$ for $10 \mathrm{~min}$ in a $1 \mathrm{M} \mathrm{NaClO}_{4}$ electrolyte. All electrochemical experiments were performed in a $20 \mathrm{~mL}$ scintillation vial using a CHI660E potentiostat, a $\mathrm{Pt}$ mesh counter electrode, and a $\mathrm{Ag} / \mathrm{AgCl}(3 \mathrm{M} \mathrm{KCl})$ reference electrode. 
Raman and SERS measurements were conducted as previously described, ${ }^{2}$ using an IX73 Olympus inverted microscope, a Teledyne Princeton Instruments SCT320 Isoplane spectrometer and ProEM HS EM-CCD camera. First, a small amount of sample was drop-cast onto the SERS substrate and mounted in the microscope. A $20 \times$ objective was then used to focus the excitation light $\left(\lambda_{\text {exc }}=532 \mathrm{~nm}, \mathrm{P}=0.5 \mathrm{~mW}\right.$, circularly polarized) onto the sample and to collect the backscattered Raman/SERS signals which were subsequently sent to the spectrometer and detector. Spectra were acquired with a $3 \mathrm{~s}$ integration time per spectrum (60 accumulations) for the $\mathrm{Ni}(\mathrm{OAc})_{2}$ and $\mathrm{Pd}(\mathrm{OAc})_{2}$ samples and a $1 \mathrm{~s}$ integration time per spectrum (60 accumulations) for the PS-750-M samples with and without Ni/Pd nanoparticles. The final spectra shown are the sum of the accumulated spectra of the respective samples. 


\section{ANALYTICAL DATA}

3-(4-(Benzyloxy)phenyl)-1-phenylpropan-1-one ${ }^{3}(2)$

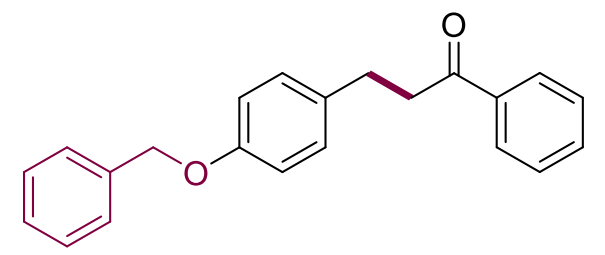

Viscous oil, yield $148 \mathrm{mg}(94 \%), R_{f} 0.21$ (1:4, EtOAc/hexanes). ${ }^{1} \mathrm{H}$ NMR (400 $\left.\mathrm{MHz}, \mathrm{CDCl}_{3}\right) \delta$ 7.87-7.85 (m, 2H), 7.58-7.54 (m, 1H), 7.47-7.32 (m, 7H), 7.18-7.17 (m, 2H), 6.93-6.91 (m, 2H), $5.05(\mathrm{~s}, 2 \mathrm{H}), 3.28(\mathrm{dd}, J=8.4,6.8 \mathrm{~Hz}, 2 \mathrm{H}), 3.12-2.88(\mathrm{~m}, 2 \mathrm{H})$.

\section{3-(4-(Naphthalen-1-ylmethoxy)phenyl)-1-phenylpropan-1-one (3)}

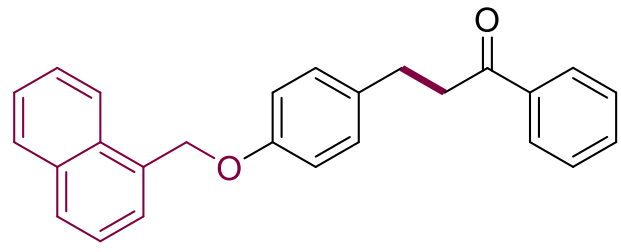

Viscous oil, yield $155 \mathrm{mg}(85 \%), R_{f} 0.23$ (1:4, EtOAc/hexanes). ${ }^{1} \mathrm{H}$ NMR (400 MHz, $\left.\mathrm{CDCl}_{3}\right) \delta$ 8.07 (d, $J=7.2 \mathrm{~Hz}, 1 \mathrm{H}), 7.99$ (d, $J=8.0 \mathrm{~Hz}, 2 \mathrm{H}), 7.92-7.86$ (m, 2H), 7.61-7.45 (m, 7H), 7.28$7.18(\mathrm{~m}, 2 \mathrm{H}), 7.02(\mathrm{~d}, J=8.0 \mathrm{~Hz}, 2 \mathrm{H}), 5.49(\mathrm{~s}, 2 \mathrm{H}), 3.31(\mathrm{t}, J=7.6 \mathrm{~Hz}, 2 \mathrm{H}), 3.06(\mathrm{t}, J=7.6 \mathrm{~Hz}$, 2H). ${ }^{13} \mathrm{C}$ NMR $\left(100 \mathrm{MHz}, \mathrm{CDCl}_{3}\right) \delta 199.4,157.4,136.9,133.9,133.1,132.5,131.6,129.6$, 129.1, 128.9, 128.7, 128.1, 128.2, 126.6, 126.5, 126.0, 125.4, 123.9, 115.1, 68.8, 40.8, 29.4. HRMS (ESI) $\left[\left(\mathrm{C}_{26} \mathrm{H}_{22} \mathrm{O}_{2}+\mathrm{H}\right)^{+}\right]$calcd $=367.1693$, found $\mathrm{m} / \mathrm{z}=367.1694$.

\section{3-(4-((3,5-Bis(trifluoromethyl)benzyl)oxy)phenyl)-1-phenylpropan-1-one (4)}

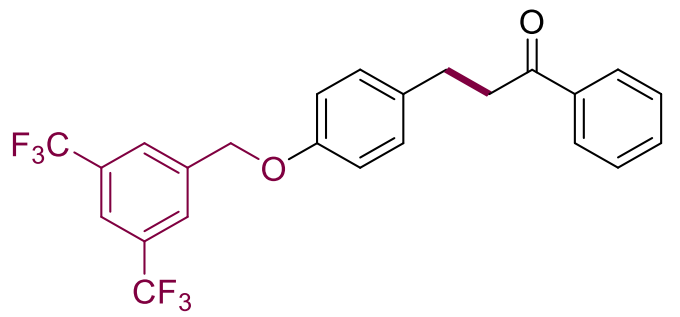

Viscous oil, yield $190 \mathrm{mg}(84 \%), R_{f} 0.24$ (1:4, EtOAc/hexanes). ${ }^{1} \mathrm{H}$ NMR (400 MHz, $\left.\mathrm{CDCl}_{3}\right) \delta$ 7.97-7.95 (m, 2H), $7.91(\mathrm{~s}, 2 \mathrm{H}), 7.85(\mathrm{~s}, 1 \mathrm{H}), 7.56(\mathrm{t}, J=7.6 \mathrm{~Hz}, 1 \mathrm{H}), 7.46(\mathrm{t}, J=7.6 \mathrm{~Hz}, 2 \mathrm{H})$, $7.22(\mathrm{~d}, J=8.6 \mathrm{~Hz}, 2 \mathrm{H}), 6.93(\mathrm{~d}, J=8.6 \mathrm{~Hz}, 2 \mathrm{H}), 5.14(\mathrm{~s}, 2 \mathrm{H}), 3.29$ (t, $J=7.6 \mathrm{~Hz}, 2 \mathrm{H}), 3.04(\mathrm{t}, J$ 
$=7.6 \mathrm{~Hz}, 2 \mathrm{H}) \cdot{ }^{19} \mathrm{~F} \mathrm{NMR}\left(376 \mathrm{MHz}, \mathrm{CDCl}_{3}\right) \delta-62.7 .{ }^{13} \mathrm{C} \mathrm{NMR}\left(100 \mathrm{MHz}, \mathrm{CDCl}_{3}\right) \delta 199.4,156.6$, 140, 137, 134.7, 133.2, 132 (q, $J=33.8 \mathrm{~Hz}), 129.8,128.5$ (q, $J=244.2 \mathrm{~Hz}), 128.2,127.4,124.7$, 122, 115, 68.7, 40.7, 29.4. HRMS (ESI) $\left[\left(\mathrm{C}_{24} \mathrm{H}_{18} \mathrm{~F}_{6} \mathrm{O}_{2}+\mathrm{H}\right)^{+}\right]$calcd $=453.1284$, found $\mathrm{m} / \mathrm{z}=$ 453.1284 .

\section{3-((4-(3-Oxo-3-phenylpropyl)phenoxy)methyl)benzonitrile (5)}

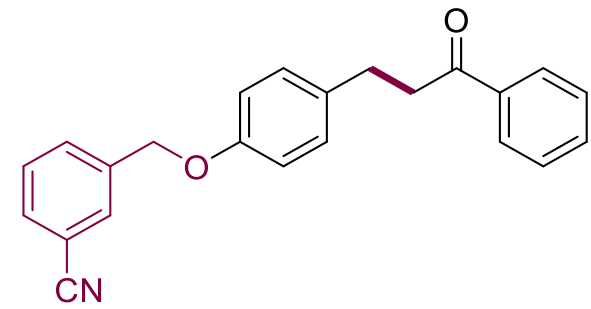

Viscous oil, yield $165 \mathrm{mg}(97 \%), R_{f} 0.5$ (1:4, EtOAc/hexanes). ${ }^{1} \mathrm{H}$ NMR $\left(400 \mathrm{MHz}, \mathrm{CDCl}_{3}\right) \delta$ $7.96(\mathrm{~d}, J=8.2 \mathrm{~Hz}, 2 \mathrm{H}), 7.74(\mathrm{~s}, 1 \mathrm{H}), 7.69-7.42(\mathrm{~m}, 6 \mathrm{H}), 7.19$ (d, J = 8.4 Hz, 2H), 6.89 (d, $J=$ $8.5 \mathrm{~Hz}, 2 \mathrm{H}), 5.07(\mathrm{~s}, 2 \mathrm{H}), 3.28(\mathrm{t}, J=7.7 \mathrm{~Hz}, 2 \mathrm{H}), 3.03$ (t, $J=7.6 \mathrm{~Hz}, 2 \mathrm{H}) .{ }^{13} \mathrm{C} \mathrm{NMR}(100 \mathrm{MHz}$, $\left.\mathrm{CDCl}_{3}\right) \delta 199.4,156.7,139.0,137.0,134.4,133.2,131.6,131.6,130.8,129.7,129.5,128.7$, 128.2, 118.8, 115.0, 112.9, 77.5, 77.2, 76.8, 68.9, 40.7, 29.4. HRMS (ESI) $\left[\left(\mathrm{C}_{23} \mathrm{H}_{19} \mathrm{NO}_{2}+\mathrm{Na}\right)^{+}\right]$ calcd $=364.1308$, found $\mathrm{m} / \mathrm{z}=364.1310$.

\section{Methyl 3-methoxy-4-((4-(3-oxo-3-phenylpropyl)phenoxy)methyl)benzoate (6)}

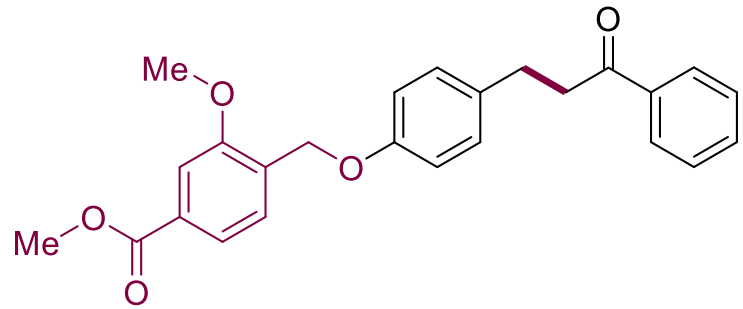

Reaction ran at $0.25 \mathrm{mmol}$ scale, yellow solid, $\mathrm{mp}=74-76{ }^{\circ} \mathrm{C}$, yield $85 \mathrm{mg}(84 \%), R_{f} 0.48(1: 9$, EtOAc/hexanes). ${ }^{1} \mathrm{H}$ NMR $\left(400 \mathrm{MHz}, \mathrm{CDCl}_{3}\right) \delta 7.89-7.84(\mathrm{~m}, 2 \mathrm{H}), 7.58(\mathrm{~d}, J=7.7 \mathrm{~Hz}, 1 \mathrm{H})$, $7.46(\mathrm{~d}, J=9.2 \mathrm{~Hz}, 3 \mathrm{H}), 7.36(\mathrm{t}, J=7.5 \mathrm{~Hz}, 2 \mathrm{H}), 7.11-7.06(\mathrm{~m}, 2 \mathrm{H}), 6.86-6.80(\mathrm{~m}, 2 \mathrm{H}), 5.04(\mathrm{~s}$, 2H), $3.83(\mathrm{~s}, 3 \mathrm{H}), 3.83(\mathrm{~s}, 3 \mathrm{H}), 3.21-3.14(\mathrm{~m}, 2 \mathrm{H}), 2.93(\mathrm{dd}, J=10.1,4.7 \mathrm{~Hz}, 2 \mathrm{H}) .{ }^{13} \mathrm{C} \mathrm{NMR}$ $\left(100 \mathrm{MHz}, \mathrm{CDCl}_{3}\right) \delta 199.4,167.0,157.2,156.4,137.0,133.8,133.1,131.1,130.5,129.5,128.7$, 128.5, 128.1, 127.7, 127.6, 126.0, 122.2, 115.0, 114.9, 110.9, 64.9, 55.7, 52.3, 40.7, 29.4. HRMS (ESI) $\left[\left(\mathrm{C}_{25} \mathrm{H}_{24} \mathrm{O}_{5}+\mathrm{Na}\right)^{+}\right]$calcd $=427.1516$, found $\mathrm{m} / \mathrm{z}=427.1517$. 
3-(4-(Benzyloxy)phenyl)-1-(4-(28uinoline-8-yl)phenyl)propan-1-one (7)<smiles>O=C(CCc1ccc(OCc2ccccc2)cc1)c1ccc(-c2cccc3cccnc23)cc1</smiles>

Viscous oil, yield $164 \mathrm{mg}(74 \%), R_{f} 0.22$ (1:4, EtOAc/hexanes). ${ }^{1} \mathrm{H}$ NMR (400 MHz, $\left.\mathrm{CDCl}_{3}\right) \delta$ $8.96(\mathrm{dd}, J=4.4,1.6 \mathrm{~Hz}, 1 \mathrm{H}), 8.23(\mathrm{dd}, J=8.4,2.0 \mathrm{~Hz}, 1 \mathrm{H}), 8.10$ (d, $J=8.4 \mathrm{~Hz}, 2 \mathrm{H}), 7.88$ (dd, $J$ $=8.0,1.2 \mathrm{~Hz}, 1 \mathrm{H}), 7.81(\mathrm{~d}, J=8.4 \mathrm{~Hz}, 2 \mathrm{H}), 7.76(\mathrm{dd}, J=7.2,1.2 \mathrm{~Hz}, 1 \mathrm{H}), 7.65-7.59(\mathrm{~m}, 1 \mathrm{H})$, 7.46-7.28 (m, 6H), $7.21(\mathrm{~d}, J=8.4 \mathrm{~Hz}, 2 \mathrm{H}), 6.94-6.90(\mathrm{~m}, 2 \mathrm{H}), 5.06(\mathrm{~s}, 2 \mathrm{H}), 3.34-3.31(\mathrm{~m}, 2 \mathrm{H})$, $3.07(\mathrm{t}, J=8.0 \mathrm{~Hz}, 2 \mathrm{H}) .{ }^{13} \mathrm{C} \mathrm{NMR}\left(100 \mathrm{MHz}, \mathrm{CDCl}_{3}\right) \delta 199.3,157.4,150.6,144.6,139.8,137.3$, $136.5,135.8,133.9,131.0,130.5,129.5,128.8,128.7,128.5,128.0,127.9,127.8,127.6,126.4$, 121.4, 115.1, 70.2, 40.8, 29.5. HRMS (ESI) $\left[\left(\mathrm{C}_{31} \mathrm{H}_{25} \mathrm{NO}_{2}+\mathrm{H}\right)^{+}\right]$calcd $=444.1958$, found $\mathrm{m} / \mathrm{z}=$ 444.1963.

\section{3-(1-Benzyl-1H-indol-5-yl)-1-phenylpropan-1-one (8)}

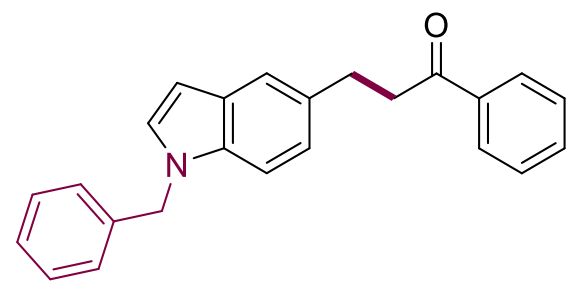

Viscous oil, yield $137 \mathrm{mg}(81 \%), R_{f} 0.25$ (1:9, EtOAc/hexanes). ${ }^{1} \mathrm{H}$ NMR (400 MHz, $\left.\mathrm{CDCl}_{3}\right) \delta$ $7.98(\mathrm{~d}, J=7.6 \mathrm{~Hz}, 2 \mathrm{H}), 7.57-7.43(\mathrm{~m}, 4 \mathrm{H}), 7.30-7.21(\mathrm{~m}, 4 \mathrm{H}), 7.12-7.07(\mathrm{~m}, 4 \mathrm{H}), 6.51(\mathrm{~d}, J=$ $2.4 \mathrm{~Hz}, 1 \mathrm{H}), 5.30(\mathrm{~s}, 2 \mathrm{H}), 3.35(\mathrm{t}, J=7.2 \mathrm{~Hz}, 2 \mathrm{H}), 3.17$ (t, $J=7.2 \mathrm{~Hz}, 2 \mathrm{H}) .{ }^{13} \mathrm{C} \mathrm{NMR}(100 \mathrm{MHz}$, $\left.\mathrm{CDCl}_{3}\right) \delta 199.8,137.7,137.1,135.2,133,132.5,129.4,129.1,128.9,128.7,128.2,127.7,126.9$, 122.7, 120.3, 109.8, 101.4, 50.3, 41.6, 30.5. HRMS (ESI) $\left[\left(\mathrm{C}_{24} \mathrm{H}_{21} \mathrm{NO}+\mathrm{H}\right)^{+}\right]$calcd $=340.1696$, found $\mathrm{m} / \mathrm{z}=340.1697$.

3-(4-(Benzyloxy)phenyl)-1-(4'-fluoro-2'-methyl-[1,1'-biphenyl]-4-yl)propan-1-one (9)<smiles>Cc1cc(F)ccc1-c1ccc(C(=O)CCc2ccc(OCc3ccccc3)cc2)cc1</smiles> 
Viscous oil, yield $163 \mathrm{mg}$ (77\%), $R_{f} 0.23$ (1:9, EtOAc/hexanes). ${ }^{1} \mathrm{H}$ NMR (400 MHz, $\left.\mathrm{CDCl}_{3}\right) \delta$ $8.01(\mathrm{~d}, J=8.0 \mathrm{~Hz}, 2 \mathrm{H}), 7.45-7.35(\mathrm{~m}, 7 \mathrm{H}), 7.25-7.13(\mathrm{~m}, 3 \mathrm{H}), 7.01-6.92(\mathrm{~m}, 4 \mathrm{H}), 5.06(\mathrm{~s}, 2 \mathrm{H})$, $3.32(\mathrm{t}, J=7.6 \mathrm{~Hz}, 2 \mathrm{H}), 3.05(\mathrm{t}, J=7.6 \mathrm{~Hz}, 2 \mathrm{H}), 2.26(\mathrm{~s}, 3 \mathrm{H}) .{ }^{19} \mathrm{~F} \mathrm{NMR}\left(376 \mathrm{MHz}, \mathrm{CDCl}_{3}\right) \delta-$ 115.1. ${ }^{13} \mathrm{C}$ NMR $\left(100 \mathrm{MHz}, \mathrm{CDCl}_{3}\right) \delta 199.1,162.4(\mathrm{~d}, J=247 \mathrm{~Hz}), 157.4,146,137.8(\mathrm{~d}, J=7.7$ $\mathrm{Hz}), 137.3,136.9,135.6,133.7,131.1$ (d, $J=8.1 \mathrm{~Hz}), 129.7,129.5$, 128.7, 128.1, 128.0, 127.6, $117.2(\mathrm{~d}, J=21.2 \mathrm{~Hz}), 115.0,112.9(\mathrm{~d}, J=21.0 \mathrm{~Hz}), 70.2,40.9,29.5,20.7$. HRMS (ESI) $\left[\left(\mathrm{C}_{29} \mathrm{H}_{25} \mathrm{FO}_{2}+\mathrm{H}\right)^{+}\right]$calcd $=425.1911$, found $=425.1915$.

\section{3-(4-((4-(Tert-butyl)benzyl)oxy)phenyl-1-phenylpropan-1-one (10)}

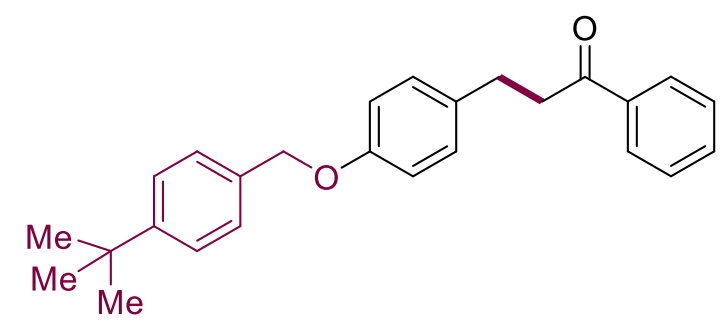

Yellow solid, $\mathrm{mp}=70-72{ }^{\circ} \mathrm{C}$, yield $=152 \mathrm{mg}(82 \%), R_{f} 0.42(1: 4 \mathrm{EtOAc} /$ hexanes $) .{ }^{1} \mathrm{H}$ NMR $(400$ $\left.\mathrm{MHz}, \mathrm{CDCl}_{3}\right) \delta 8.00(\mathrm{~d}, J=8.0 \mathrm{~Hz}, 2 \mathrm{H}), 7.59(\mathrm{t}, J=7.4 \mathrm{~Hz}, 1 \mathrm{H}), 7.51-7.39(\mathrm{~m}, 6 \mathrm{H}), 7.22(\mathrm{~d}, J=$ $8.5 \mathrm{~Hz}, 2 \mathrm{H}), 6.98$ (d, $J=8.5 \mathrm{~Hz}, 2 \mathrm{H}), 5.05$ (s, 2H), 3.31 (t, $J=7.6 \mathrm{~Hz}, 2 \mathrm{H}), 3.07$ (t, $J=7.6 \mathrm{~Hz}$, 2H), $1.38(\mathrm{~s}, 9 \mathrm{H}) .{ }^{13} \mathrm{C} \mathrm{NMR}\left(100 \mathrm{MHz}, \mathrm{CDCl}_{3}\right) \delta 199.4,157.4,151.0,137.0,134.1,133.6$, 133.1, 129.4, 128.7, 128.1, 127.5, 125.6, 114.9, 77.5, 77.2, 76.8, 70.0, 40.7, 34.6, 31.4, 29.4. HRMS (ESI) $\left[\left(\mathrm{C}_{26} \mathrm{H}_{28} \mathrm{O}_{2}+\mathrm{Na}\right)^{+}\right]$calcd $=395.1982$, found $\mathrm{m} / \mathrm{z}=395.1984$.

\section{1-Phenyl-3-(4-((4-(pyren-1-yl)benzyl)oxy)phenyl)propan-1-one (11)}

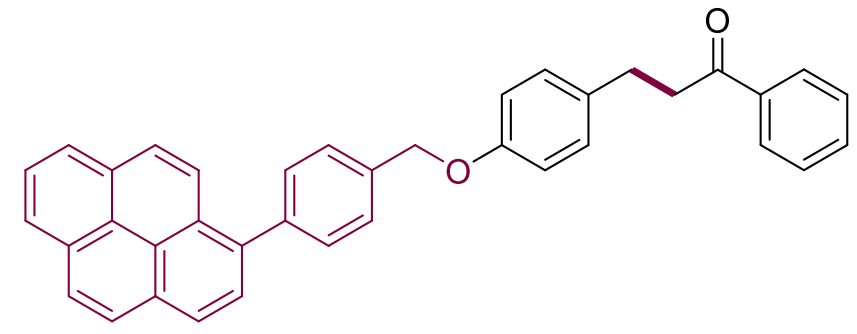

Viscous oil, yield $204 \mathrm{mg}$ (79\%), $R_{f} 0.24$ (1:4, EtOAc/hexanes). ${ }^{1} \mathrm{H}$ NMR (400 MHz, $\left.\mathrm{CDCl}_{3}\right) \delta$ 8.24-8.16 (m, 4H), 8.10 (d, $J=1.4 \mathrm{~Hz}, 2 \mathrm{H}), 8.04-7.96$ (m, 5H), 7.65 (q, $J=8.0 \mathrm{~Hz}, 4 \mathrm{H}), 7.56$ (dd, $J=10.5,4.3 \mathrm{~Hz}, 1 \mathrm{H}), 7.46$ (t, $J=6.9 \mathrm{~Hz}, 2 \mathrm{H}), 7.27-7.23(\mathrm{~m}, 2 \mathrm{H}), 7.01(\mathrm{~d}, J=7.2 \mathrm{~Hz}, 2 \mathrm{H})$, 5.19 (s, 2H), 3.31 (t, $J=7.6 \mathrm{~Hz}, 2 \mathrm{H}), 3.06(\mathrm{t}, J=7.6 \mathrm{~Hz}, 2 \mathrm{H}) .{ }^{13} \mathrm{C} \mathrm{NMR}\left(100 \mathrm{MHz}, \mathrm{CDCl}_{3}\right) \delta$ 
199.5, 157.5, 143.0, 141.0, 137.4, 137.0, 136.3, 133.9, 133.2, 131.6, 131.1, 130.9, 130.8, 129.9, 129.6, 129.3, 129.0, 128.7, 128.6, 128.2, 127.7, 127.6, 127.5, 126.2, 125.6, 125.3, 125.0, 124.8, 124.6, 115.1, 70.1, 40.8, 29.5. HRMS (ESI) $\left[\left(\mathrm{C}_{38} \mathrm{H}_{28} \mathrm{O}_{2}+\mathrm{H}\right)^{+}\right]$calcd $=517.2162$, found $\mathrm{m} / \mathrm{z}=$ 517.2163.

\section{3-(4-(Benzyloxy)phenyl)-1-(4-(dibenzo[b,d]furan-4-yl)phenyl)propan-1-one (12)}

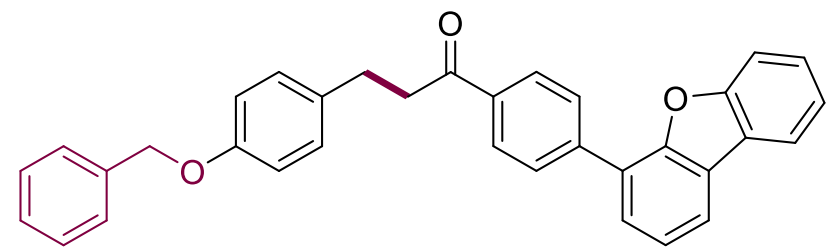

Sticky solid, $\mathrm{mp}=109-110{ }^{\circ} \mathrm{C}$, yield $183 \mathrm{mg}(76 \%), R_{f} 0.23$ (1:9, EtOAc/hexanes). ${ }^{1} \mathrm{H}$ NMR $\left(400 \mathrm{MHz}, \mathrm{CDCl}_{3}\right) \delta 8.13$ (d, $\left.J=8.4 \mathrm{~Hz}, 2 \mathrm{H}\right), 8.04-7.98(\mathrm{~m}, 4 \mathrm{H}), 7.65-7.60(\mathrm{~m}, 2 \mathrm{H}), 7.49-7.33$ (m, 8H), $7.21(\mathrm{~d}, J=8.0 \mathrm{~Hz}, 2 \mathrm{H}), 6.99-6.93(\mathrm{~m}, 2 \mathrm{H}), 5.06(\mathrm{~s}, 2 \mathrm{H}), 3.35(\mathrm{t}, J=7.6 \mathrm{~Hz}, 2 \mathrm{H}), 3.07$ $(\mathrm{t}, J=7.6 \mathrm{~Hz}, 2 \mathrm{H}) .{ }^{13} \mathrm{C} \mathrm{NMR}\left(100 \mathrm{MHz}, \mathrm{CDCl}_{3}\right) \delta 199.1,157.4,156.3,141.3,137.3,136.0$, 133.8, 129.6, 129.1, 128.9, 128.8, 128.6, 128.4, 128.1, 127.6, 126.9, 125.3, 124.71, 124.1, 123.5, 123.1, 120.9, 120.8, 115.1, 112.0, 70.2, 40.9, 29.5. HRMS (ESI) $\left[\left(\mathrm{C}_{34} \mathrm{H}_{26} \mathrm{O}_{3}+\mathrm{H}\right)^{+}\right]$calcd $=$ 483.1955 , found $\mathrm{m} / \mathrm{z}=483.1957$.

3-(4-((5'-Acetyl-2'-fluoro-[1,1'-biphenyl]-4-yl)methoxy)phenyl)-1-phenylpropan-1-one (13)

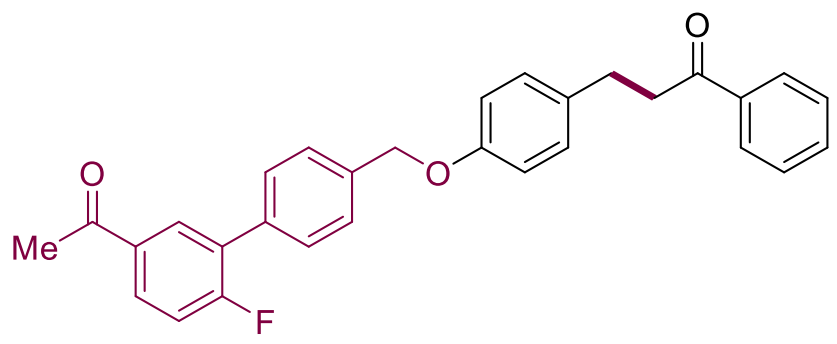

Viscous oil, yield $183 \mathrm{mg}(81 \%), R_{f} 0.24$ (1:4, EtOAc/hexanes). ${ }^{1} \mathrm{H}$ NMR (400 MHz, $\left.\mathrm{CDCl}_{3}\right) \delta$ $8.14(\mathrm{dd}, J=7.5,2.3 \mathrm{~Hz}, 1 \mathrm{H}), 8.04-7.97(\mathrm{~m}, 3 \mathrm{H}), 7.68-7.56(\mathrm{~m}, 5 \mathrm{H}), 7.51(\mathrm{dd}, J=10.8,4.4 \mathrm{~Hz}$, 2H), 7.31-7.24 (m, 3H), 7.01-6.98 (m, 2H), $5.16(\mathrm{~s}, 2 \mathrm{H}), 3.33(\mathrm{dd}, J=8.3,7.0 \mathrm{~Hz}, 2 \mathrm{H}), 3.08(\mathrm{t}, J$ $=7.6 \mathrm{~Hz}, 2 \mathrm{H}), 2.68(\mathrm{~s}, 3 \mathrm{H}) .{ }^{19} \mathrm{~F}$ NMR $\left(376 \mathrm{MHz}, \mathrm{CDCl}_{3}\right) \delta-110.3 .{ }^{13} \mathrm{C} \mathrm{NMR}\left(100 \mathrm{MHz}, \mathrm{CDCl}_{3}\right)$ $\delta 199.4,196.6,164,161.5,157.2,137.4,135.6(\mathrm{~d}, J=257.4 \mathrm{~Hz}), 133.8,133.1,131.5(\mathrm{~d}, J=4.6$ Hz), 129.7, 129.6, 129.5, 129.3, 129.0, 128.6, 128.1, 127.7, 116.6 (d, J=23.7 Hz), 114.97, 69.7, 40.7, 29.3, 26.7. HRMS (ESI) $\left[\left(\mathrm{C}_{30} \mathrm{H}_{25} \mathrm{FO}_{3}+\mathrm{Na}\right)^{+}\right]$calcd $=475.1680$, found $\mathrm{m} / \mathrm{z}=475.1680$. 
1-Phenyl-3-(4-((4-(1-(phenylsulfonyl)-1H-indol-3-yl)benzyl)oxy)phenyl)propan-1-one (14)

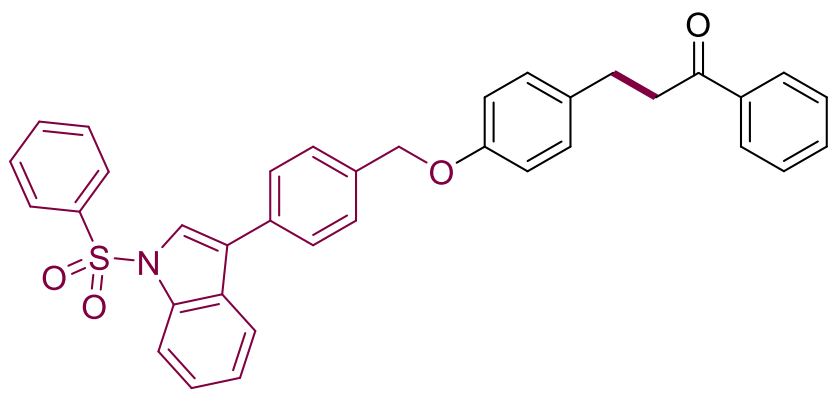

Reaction ran at $0.25 \mathrm{mmol}$ scale, sticky solid, $\mathrm{mp}=135-136{ }^{\circ} \mathrm{C}$, yield $117 \mathrm{mg}(82 \%), R_{f} 0.25$ (1:4, EtOAc/hexanes). ${ }^{1} \mathrm{H}$ NMR (400 $\mathrm{MHz}^{\left.\mathrm{CDCl}_{3}\right)} \delta 7.97(\mathrm{~d}, J=8.3 \mathrm{~Hz}, 1 \mathrm{H}), 7.87-7.81$ (m, 4H), $7.67(\mathrm{~d}, J=7.9 \mathrm{~Hz}, 1 \mathrm{H}), 7.61(\mathrm{~d}, J=1.0 \mathrm{~Hz}, 1 \mathrm{H}), 7.53-7.14(\mathrm{~m}, 12 \mathrm{H}), 7.09$ (d, $J=7.6 \mathrm{~Hz}$, 2H), $6.84(\mathrm{~d}, J=7.6 \mathrm{~Hz}, 2 \mathrm{H}), 4.99(\mathrm{~s}, 2 \mathrm{H}), 3.18(\mathrm{t}, J=7.6 \mathrm{~Hz}, 2 \mathrm{H}), 2.93(\mathrm{t}, J=7.6 \mathrm{~Hz}, 2 \mathrm{H}) .{ }^{13} \mathrm{C}$ NMR $\left(100 \mathrm{MHz}, \mathrm{CDCl}_{3}\right) \delta 199.5,157.3,138.2,136.9,136.7,135.6,134.0,133.9,133.2,132.8$, $129.6,129.5,129.4,128.7,128.3,128.2$, 128.0, 126.9, 125.2, 123.9, 123.8, 123.1, 120.6, 115.0, 113.9, 69.9, 40.8, 29.4. HRMS (ESI) $\left[\left(\mathrm{C}_{36} \mathrm{H}_{29} \mathrm{NSO}_{4}+\mathrm{Na}\right)^{+}\right]$calcd $=594.1709$, found $\mathrm{m} / \mathrm{z}=$ 594.1710.

1,3-Dihydro-3-(2-oxo-2-phenylethyl)-1-(phenylmethyl)indol-2-one (CAS No: 31535-70-3) (15)

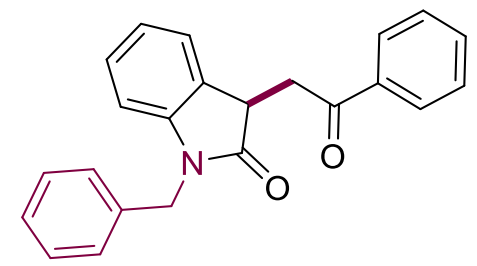

Viscous oil, yield $40 \mathrm{mg}(80 \%), R_{f} 0.25$ (1:9, EtOAc/hexanes). ${ }^{1} \mathrm{H}$ NMR $\left(400 \mathrm{MHz}, \mathrm{CDCl}_{3}\right) \delta$ $7.45(\mathrm{~d}, J=7.6 \mathrm{~Hz}, 2 \mathrm{H}), 7.07-7.05(\mathrm{~m}, 1 \mathrm{H}), 6.98-6.94(\mathrm{~m}, 2 \mathrm{H}), 6.85-6.78(\mathrm{~m}, 4 \mathrm{H}), 6.75-6.73(\mathrm{~m}$, 2H), 6.64-6.62 (m, 1H), 6.45 (t, $J=7.6 \mathrm{~Hz}, 1 \mathrm{H}), 6.23$ (d, J=7.6 Hz, 1H), 4.47 (s, 2H), 3.67 (d, $J$ $=8.8 \mathrm{~Hz}, 1 \mathrm{H}), 3.39(\mathrm{~d}, J=8.8 \mathrm{~Hz}, 1 \mathrm{H}), 2.57(\mathrm{dd}, J=18.0,8.8 \mathrm{~Hz}, 1 \mathrm{H})$. 


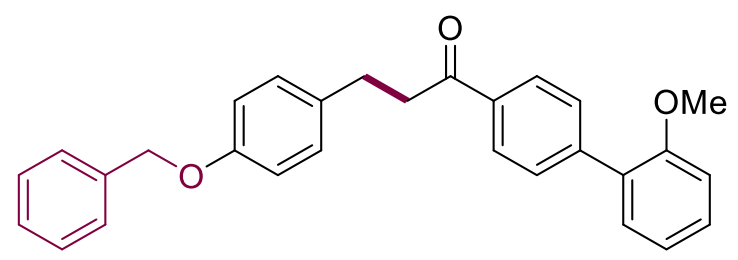

Reaction ran at $0.25 \mathrm{mmol}$ scale, viscous oil, yield $102 \mathrm{mg}$ (97\%), $R_{f} 0.44$ (1:9 EtOAc/hexanes). ${ }^{1} \mathrm{H}$ NMR (400 MHz, $\left.\mathrm{CDCl}_{3}\right) \delta 8.04(\mathrm{~d}, J=8.3 \mathrm{~Hz}, 2 \mathrm{H}), 7.67(\mathrm{~d}, J=8.3 \mathrm{~Hz}, 2 \mathrm{H}), 7.48-7.36(\mathrm{~m}$, 7H), $7.23(\mathrm{~d}, J=8.5 \mathrm{~Hz}, 2 \mathrm{H}), 7.11-7.03(\mathrm{~m}, 2 \mathrm{H}), 6.97$ (d, $J=8.5 \mathrm{~Hz}, 2 \mathrm{H}), 5.08(\mathrm{~s}, 2 \mathrm{H}), 3.85(\mathrm{~s}$, $3 \mathrm{H}), 3.33$ (dd, $J=10.0,5.3 \mathrm{~Hz}, 2 \mathrm{H}), 3.08$ (t, $J=7.7 \mathrm{~Hz}, 2 \mathrm{H}) .{ }^{13} \mathrm{C}$ NMR $\left(100 \mathrm{MHz}, \mathrm{CDCl}_{3}\right) \delta$ 199.3, 157.3, 156.5, 143.6, 137.3, 135.3, 133.8, 130.8, 129.8, 129.6, 129.5, 128.7, 128.0, 127.9, $127.6,121.1,115.5,115.0,111.4,77.5,77.2,76.8,70.2,55.7,40.8,29.5$. HRMS (ESI) $\left[\left(\mathrm{C}_{29} \mathrm{H}_{26} \mathrm{O}_{3}+\mathrm{Na}\right)^{+}\right]$calcd $=445.1774$, found $\mathrm{m} / \mathrm{z}=445.1775$.

4'-(3-(4-(Benzyloxy)phenyl)propanoyl)-4-fluoro-[1,1'-biphenyl]-2-carbaldehyde (17)<smiles>O=Cc1cc(F)ccc1-c1ccc(C(=O)CCc2ccc(OCc3ccccc3)cc2)cc1</smiles>

Viscous oil, yield $179 \mathrm{mg}(82 \%), R_{f} 0.26$ (1:4, EtOAc/hexanes). ${ }^{1} \mathrm{H}$ NMR (400 MHz, $\left.\mathrm{CDCl}_{3}\right) \delta$ $9.87(\mathrm{~s}, 1 \mathrm{H}), 8.11-8.05(\mathrm{~m}, 3 \mathrm{H}), 7.51-7.28(\mathrm{~m}, 7 \mathrm{H}), 7.26-7.11(\mathrm{~m}, 4 \mathrm{H}), 6.93(\mathrm{~d}, J=8.4 \mathrm{~Hz}, 2 \mathrm{H})$, $5.05(\mathrm{~s}, 2 \mathrm{H}), 3.33$ (t, $J=7.6 \mathrm{~Hz}, 2 \mathrm{H}), 3.06(\mathrm{t}, J=7.6 \mathrm{~Hz}, 2 \mathrm{H}) .{ }^{19} \mathrm{~F} \mathrm{NMR}\left(376 \mathrm{MHz}, \mathrm{CDCl}_{3}\right) \delta-$ 103.4. ${ }^{13} \mathrm{C}$ NMR $\left(100 \mathrm{MHz}, \mathrm{CDCl}_{3}\right) \delta 198.8,190.1,165.6(\mathrm{~d}, J=260 \mathrm{~Hz}), 157.4,147.5(\mathrm{~d}, J=$ $9.2 \mathrm{~Hz}), 141.3,137.3,136.9,133.5,131.2$ (d, $J=9.7 \mathrm{~Hz}), 130.4,130.3,129.5,128.7,128.4$, 128.1, 127.6, 117.5 (d, $J=22.3 \mathrm{~Hz}), 116.2,116.1$ (d, $J=21.7 \mathrm{~Hz}), 70.2,40.9,29.4$. HRMS (ESI) $\left[\left(\mathrm{C}_{29} \mathrm{H}_{23} \mathrm{FO}_{3}+\mathrm{H}\right)^{+}\right]$calcd $=439.1704$, found in $\mathrm{m} / \mathrm{z}=439.1706$.

3-(Furan-2-yl)-1-phenylpropan-1-one (CAS No: 2207-63-8) (18)<smiles>O=C(CCc1ccco1)c1ccccc1</smiles> 
Viscous oil, yield $90 \mathrm{mg}(90 \%), R_{f} 0.25$ (1:9, EtOAc/hexanes). ${ }^{1} \mathrm{H}$ NMR $\left(400 \mathrm{MHz}, \mathrm{CDCl}_{3}\right) \delta$ $7.99(\mathrm{~d}, J=7.2 \mathrm{~Hz}, 2 \mathrm{H}), 7.58-7.56(\mathrm{~m}, 1 \mathrm{H}), 7.49-7.46(\mathrm{~m}, 2 \mathrm{H}), 7.33(\mathrm{~s}, 1 \mathrm{H}), 6.31(\mathrm{~s}, 1 \mathrm{H}), 6.08$ (s, $1 \mathrm{H}), 3.35(\mathrm{t}, J=7.6 \mathrm{~Hz}, 2 \mathrm{H}), 3.12(\mathrm{t}, J=7.6 \mathrm{~Hz}, 2 \mathrm{H})$.

\section{1-Phenyl-3-(thiophen-3-yl)propan-1-one ${ }^{4}(19)$}

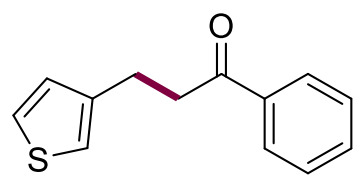

White solid, yield $103 \mathrm{mg}(95 \%), R_{f} 0.24$ (1:19, EtOAc/hexanes). ${ }^{1} \mathrm{H}$ NMR (500 MHz, $\left.\mathrm{CDCl}_{3}\right) \delta$ $7.81(\mathrm{~d}, J=7 \mathrm{~Hz}, 2 \mathrm{H}), 7.41-7.38(\mathrm{~m}, 1 \mathrm{H}), 7.30$ (t, $J=7.6 \mathrm{~Hz}, 2 \mathrm{H}), 7.10-7.09$ (m, 1H), 6.85-6.83 (m, 2H), $3.14(\mathrm{t}, J=7.6 \mathrm{~Hz}, 2 \mathrm{H}), 2.94(\mathrm{t}, J=7.6 \mathrm{~Hz}, 2 \mathrm{H})$.

\section{3-(1H-Indol-5-yl)-1-phenylpropan-1-one ${ }^{5}(20)$}

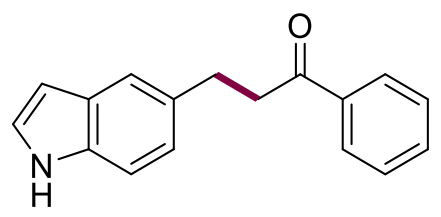

Yellow oil, yield $114 \mathrm{mg}(92 \%), R_{f} 0.22$ (1:5, EtOAc/hexanes). ${ }^{1} \mathrm{H} \mathrm{NMR}\left(400 \mathrm{MHz}, \mathrm{CDCl}_{3}\right) \delta$ $8.22(\mathrm{~s}, 1 \mathrm{H}), 8.00$ (d, $J=7.4 \mathrm{~Hz}, 2 \mathrm{H}), 7.58-7.55(\mathrm{~m}, 2 \mathrm{H}), 7.47$ (t, $J=7.6 \mathrm{~Hz}, 2 \mathrm{H}), 7.34$ (d, $J=$ $8.4 \mathrm{~Hz}, 1 \mathrm{H}), 7.19$ (s, 1H), 7.12 (d, $J=8.4 \mathrm{~Hz}, 1 \mathrm{H}), 6.52$ (s, 1H), 3.37 (t, $J=7.6 \mathrm{~Hz}, 2 \mathrm{H}), 3.19$ (t, $J=7.6 \mathrm{~Hz}, 2 \mathrm{H})$.

\section{3-(4-((Tert-butyldimethylsilyl)oxy)phenyl)-1-phenylpropan-1-one (21)}

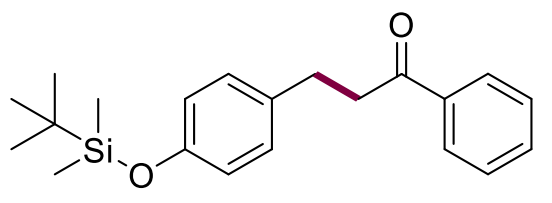

Viscous oil, yield $139 \mathrm{mg}(82 \%), R_{f} 0.27$ (1:9, EtOAc/hexanes). ${ }^{1} \mathrm{H}$ NMR (400 MHz, $\left.\mathrm{CDCl}_{3}\right) \delta$ $7.98(\mathrm{~d}, J=7.3 \mathrm{~Hz}, 2 \mathrm{H}), 7.57-7.55(\mathrm{~m}, 1 \mathrm{H}), 7.46$ (t, $J=7.8 \mathrm{~Hz}, 2 \mathrm{H}), 7.12$ (d, $J=8.3 \mathrm{~Hz}, 2 \mathrm{H})$,

$6.79(\mathrm{~d}, J=8.3 \mathrm{~Hz}, 2 \mathrm{H}), 3.30-3.26(\mathrm{~m}, 2 \mathrm{H}), 3.04-3.00(\mathrm{~m}, 2 \mathrm{H}), 1.01(\mathrm{~s}, 9 \mathrm{H}), 0.21(\mathrm{~s}, 6 \mathrm{H}) .{ }^{13} \mathrm{C}$ NMR (100 MHz, $\left.\mathrm{CDCl}_{3}\right) \delta 199.5,154.0,137.0,133.9,133.1,129.4,128.7,128.1,120.1,40.8$, 29.5, 25.8, 18.3, -4.3. HRMS (ESI) $\left.\left[\mathrm{C}_{21} \mathrm{H}_{28} \mathrm{SiO}_{2}+\mathrm{H}\right)^{+}\right]$calcd $=341.1931$, found $\mathrm{m} / \mathrm{z}=341.1935$. 


\section{4-(3-Oxo-3-phenylpropyl)phenyl 4-methylbenzenesulfonate (22)}

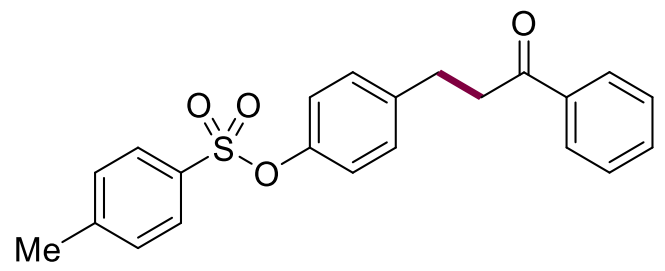

Viscous oil, yield $166 \mathrm{mg}(88 \%), R_{f} 0.25$ (1:9, EtOAc/hexanes). ${ }^{1} \mathrm{H}$ NMR (400 MHz, $\left.\mathrm{CDCl}_{3}\right) \delta$ $7.93(\mathrm{~d}, J=7.2 \mathrm{~Hz}, 2 \mathrm{H}), 7.70$ (d, $J=7.2 \mathrm{~Hz}, 2 \mathrm{H}), 7.55$ (d, $J=7.4 \mathrm{~Hz}, 1 \mathrm{H}), 7.45$ (t, $J=7.4 \mathrm{~Hz}$, 2H), 7.35-7.22 (m, 2H), $7.16(\mathrm{~d}, J=8.4 \mathrm{~Hz}, 2 \mathrm{H}), 6.89(\mathrm{~d}, J=8.4 \mathrm{~Hz}, 2 \mathrm{H}), 3.26(\mathrm{t}, J=7.5 \mathrm{~Hz}$, 2H), $3.03(\mathrm{t}, J=7.5 \mathrm{~Hz}, 2 \mathrm{H}), 2.44(\mathrm{~s}, 3 \mathrm{H}) .{ }^{13} \mathrm{C} \mathrm{NMR}\left(100 \mathrm{MHz}, \mathrm{CDCl}_{3}\right) \delta 198.9,148.1,145.4$, $140.5,136.9,133.3,132.6,129.8,129.7,128.8,128.6,128.1,122.5,40.2,29.5,21.9$. HRMS $(\mathrm{ESI})\left[\left(\mathrm{C}_{22} \mathrm{H}_{20} \mathrm{SO}_{4}+\mathrm{H}\right)^{+}\right]$calcd $=381.1158$, found $\mathrm{m} / \mathrm{z}=381.1155$.

\section{3-(Anthracen-9-yl)-1-phenylpropan-1-one ${ }^{6}(23)$}

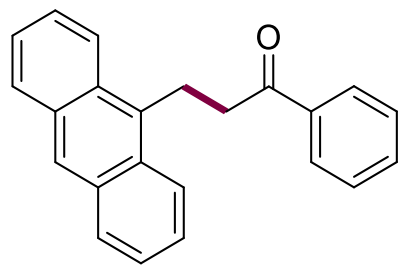

Viscous oil, yield $140 \mathrm{mg}(90 \%), \mathrm{R}_{f} 0.4$ (1:4 EtOAc/hexanes). ${ }^{1} \mathrm{H}$ NMR (500 MHz, $\left.\mathrm{CDCl}_{3}\right) \delta$ $8.39(\mathrm{~s}, 1 \mathrm{H}), 8.28(\mathrm{~d}, J=8.8 \mathrm{~Hz}, 2 \mathrm{H}), 8.04(\mathrm{~d}, J=8.3 \mathrm{~Hz}, 2 \mathrm{H}), 7.96(\mathrm{~d}, J=7.5 \mathrm{~Hz}, 2 \mathrm{H}), 7.58-$ 7.40 (m, 7H), 4.14-4.04 (m, 2H), 3.50-3.42 (m, 2H).

\section{1,3-Diphenylpropan-1-one (CAS No: 1083-30-3) (24)}<smiles>O=C(CCc1ccccc1)c1ccccc1</smiles>

Viscous oil, yield $92 \mathrm{mg}(88 \%), R_{f} 0.23$ (1:5, EtOAc/hexanes). ${ }^{1} \mathrm{H}$ NMR $\left(500 \mathrm{MHz}, \mathrm{CDCl}_{3}\right) \delta$ 7.99-7.97 (m, 2H), 7.58-7.55 (m, 1H), 7.48-7.45 (m, 2H), 7.34-7.21 (m, 5H), 3.33-3.30 (m, 2H), 3.11-3.08 (m, 2H).

2-Benzyl-5-benzylidenecyclopentanone ${ }^{7}$ (25) 


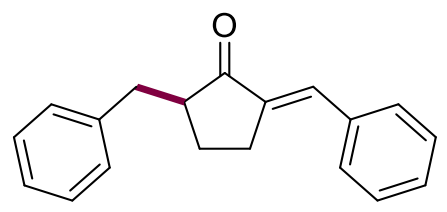

Viscous oil, yield $73 \mathrm{mg}(56 \%), R_{f} 0.26$ (1:4, EtOAc/hexanes). ${ }^{1} \mathrm{H}$ NMR (500 MHz, $\left.\mathrm{CDCl}_{3}\right) \delta$ $7.54(\mathrm{~d}, J=7.4 \mathrm{~Hz}, 2 \mathrm{H}), 7.45-7.35(\mathrm{~m}, 4 \mathrm{H}), 7.33-7.28(\mathrm{~m}, 2 \mathrm{H}), 7.23-7.19(\mathrm{~m}, 3 \mathrm{H}), 3.33$ (dd, $J=$ 12.9, 3.0 Hz, 1H), 2.97 (dd, $J=17.0,8.0 \mathrm{~Hz}, 1 \mathrm{H}), 2.79-2.76$ (m, 1H), 2.65-2.57 (m, 2H), 2.19$2.17(\mathrm{~m}, 1 \mathrm{H}), 1.63-1.57(\mathrm{~m}, 1 \mathrm{H})$.

4-(3-Oxo-3-phenylpropyl)phenyl 1,3,5-trimethyl-1 $H$-pyrazole-4-sulfonate (26)<smiles>Cc1nn(C)c(C)c1S(=O)(=O)Oc1ccc(CCC(=O)c2ccccc2)cc1</smiles>

Viscous oil, yield $163 \mathrm{mg}$ (82\%), $R_{f} 0.3$ (1:4, EtOAc/hexanes). ${ }^{1} \mathrm{H}$ NMR (400 MHz, $\left.\mathrm{CDCl}_{3}\right) \delta$ $7.94(\mathrm{~d}, J=7.6 \mathrm{~Hz}, 2 \mathrm{H}), 7.57-7.44(\mathrm{~m}, 3 \mathrm{H}), 7.19(\mathrm{~d}, J=8.4 \mathrm{~Hz}, 2 \mathrm{H}), 6.95(\mathrm{~d}, J=8.4 \mathrm{~Hz}, 2 \mathrm{H})$, 3.71 (s, 3H), 3.28 (t, $J=7.4 \mathrm{~Hz}, 2 \mathrm{H}), 3.06$ (t, $J=7.4 \mathrm{~Hz}, 2 \mathrm{H}), 2.24$ (s, 3H), 2.22 (s, 3H). ${ }^{13} \mathrm{C}$ NMR $\left(100 \mathrm{MHz}, \mathrm{CDCl}_{3}\right) \delta 198.8,148.9,147.8,143.8,140.5,136.8,133.3,129.7,128.8,128.6$, 128.1, 122.7, 40.1, 36.6, 29.5, 12.9, 10.5. HRMS (ESI) $\left[\left(\mathrm{C}_{21} \mathrm{H}_{22} \mathrm{O}_{4} \mathrm{~N}_{2} \mathrm{~S}+\mathrm{H}\right)^{+}\right]$calcd $=399.1373$, found $\mathrm{m} / \mathrm{z}=399.1375$.

\section{2-Benzylmalononitrile (CAS No: 1867-37-4) (27)}<smiles>N#CC(C#N)Cc1ccccc1</smiles>

Viscous oil, yield $72 \mathrm{mg}$ (92\%), $R_{f} 0.23$ (1:5, EtOAc/hexanes). ${ }^{1} \mathrm{H}$ NMR (400 MHz, $\left.\mathrm{CDCl}_{3}\right) \delta$ 7.38-7.28 (m, 5H), $3.87(\mathrm{t}, J=6.9 \mathrm{~Hz}, 1 \mathrm{H}), 3.25$ (d, $J=6.9 \mathrm{~Hz}, 2 \mathrm{H})$.

\section{2-(3-Nitrobenzyl)malononitrile ${ }^{8}(28)$}<smiles>N#CC(C#N)Cc1cccc([N+](=O)[O-])c1</smiles>

Viscous oil, yield $72 \mathrm{mg}(72 \%), R_{f} 0.25$ (3:7, EtOAc/hexanes). ${ }^{1} \mathrm{H}$ NMR (400 MHz, $\left.\mathrm{CDCl}_{3}\right) \delta$ 8.29-8.23 (m, 2H), 7.73-7.62 (m, 2H), $4.05(\mathrm{t}, J=6.8 \mathrm{~Hz}, 1 \mathrm{H}), 3.43(\mathrm{~d}, J=6.8 \mathrm{~Hz}, 2 \mathrm{H})$. 


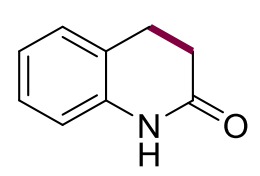

Viscous oil, yield $50 \mathrm{mg}(68 \%), R_{f} 0.24$ (1:9, EtOAc/hexanes). ${ }^{1} \mathrm{H}$ NMR $\left(400 \mathrm{MHz}, \mathrm{CDCl}_{3}\right) \delta$ $8.90(\mathrm{~s}, 1 \mathrm{H}), 7.19-7.15(\mathrm{~m}, 2 \mathrm{H}), 6.99(\mathrm{t}, J=7.2 \mathrm{~Hz}, 1 \mathrm{H}), 6.82(\mathrm{~d}, J=7.2 \mathrm{~Hz}, 1 \mathrm{H}), 2.97(\mathrm{t}, J=7.4$ $\mathrm{Hz}, 2 \mathrm{H}), 2.65$ (t, $J=7.4 \mathrm{~Hz}, 2 \mathrm{H})$.

1-Benzyl-3-hydroxyindolin-2-one (CAS No: 92552-73-3) (31)

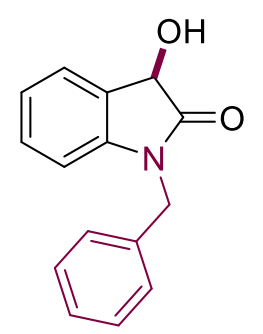

Colorless oil, yield $99 \mathrm{mg}(83 \%), R_{f} 0.25$ (3:7, EtOAc/hexanes). ${ }^{1} \mathrm{H}$ NMR (400 $\left.\mathrm{MHz}, \mathrm{CDCl}_{3}\right) \delta$ $7.60(\mathrm{~d}, J=7.2 \mathrm{~Hz}, 1 \mathrm{H}), 7.43-7.32(\mathrm{~m}, 6 \mathrm{H}), 7.19(\mathrm{t}, J=7.6 \mathrm{~Hz}, 1 \mathrm{H}), 6.84(\mathrm{~d}, J=7.6 \mathrm{~Hz}, 1 \mathrm{H})$, $5.36(\mathrm{~s}, 1 \mathrm{H}), 5.09-4.92(\mathrm{~m}, 2 \mathrm{H}), 4.78(\mathrm{~s}, 1 \mathrm{H})$. 


\section{REFERENCES}

1. Brals, J.; Smith, J. D.; Ibrahim, F.; Gallou, F.; Handa, S. ACS Catal. 2017, 7, 7245-7250

2. Ansari, T. N.; Sharma, S.; Hazra, S.; Jasinski, J. B.; Wilson, A. J.; Hicks, F.; Leahy, D. K.; Handa, S. JACS Au 2021, 1, 1506-1513.

3. Ding, Z-C.; Li, C-Y.; Chen, J-J.; Zeng, J-H.; Tang, H-T.; Ding, Y-J.; Zhan, Z-P. Adv. Synth. Catal. 2017, 359, 2280-2287

4. Zen-ichi, Y.; Yoshimi, Y.; Yoshinao, T. Tetrahedron 1979, 3, 329-340

5. Li, W.; Wu, X-F. Eur. J. Org. Chem. 2015, 331-335

6. Hans-Gerd, L.; Carsten, B.; Hans-Dieter, B. J. Photochem. Photobiol. A Chem, 1995, 86, 133-139

7. Turowska-Tyrk, I. Chem. Eur. J. 2001, 7, 3401-3405

8. Wang, J.; Song, G.; Peng, Y.; Zhu, Y. Tetrahedron Lett. 2008, 49, 6518-6520. 
12. NMR SPECTRA

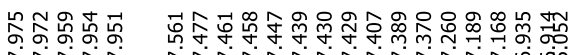

然然

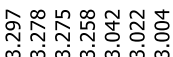

匀<smiles>O=C(CCc1ccc(OCc2ccccc2)cc1)c1ccccc1</smiles>

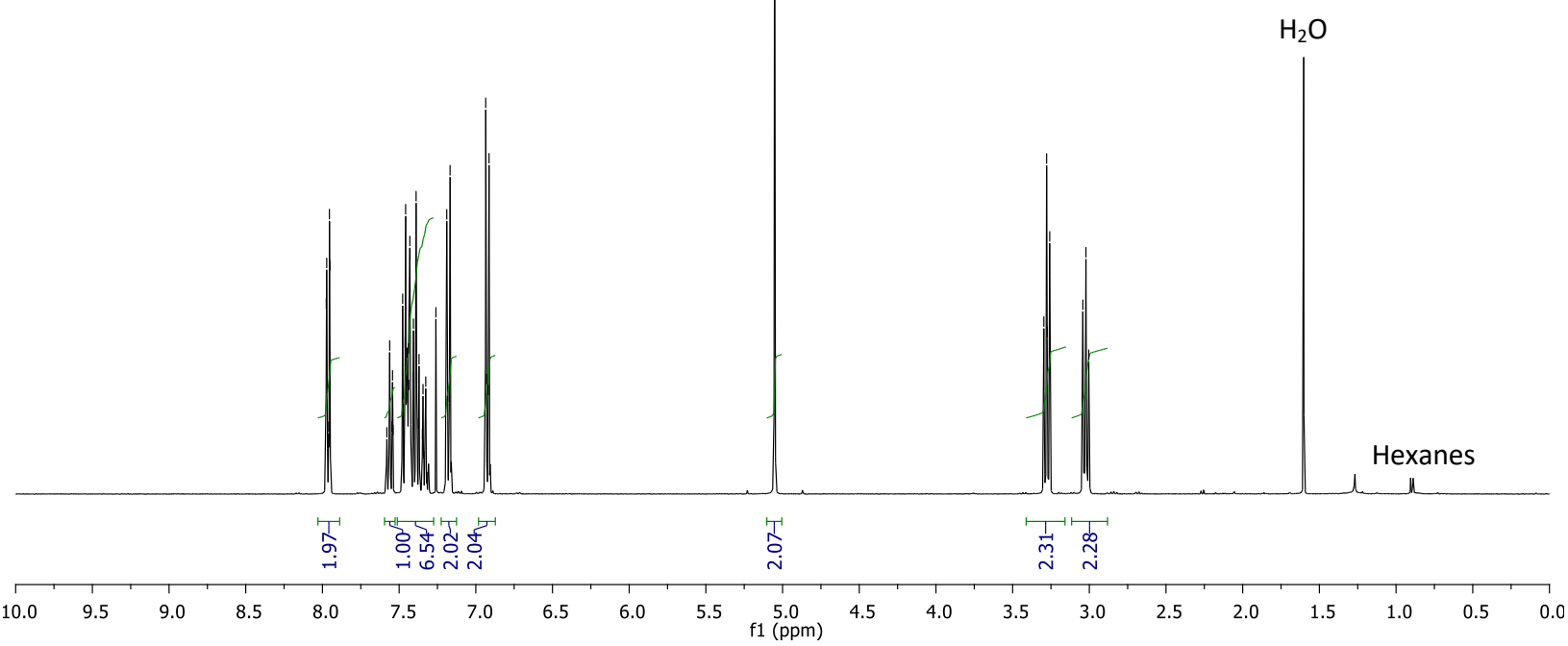



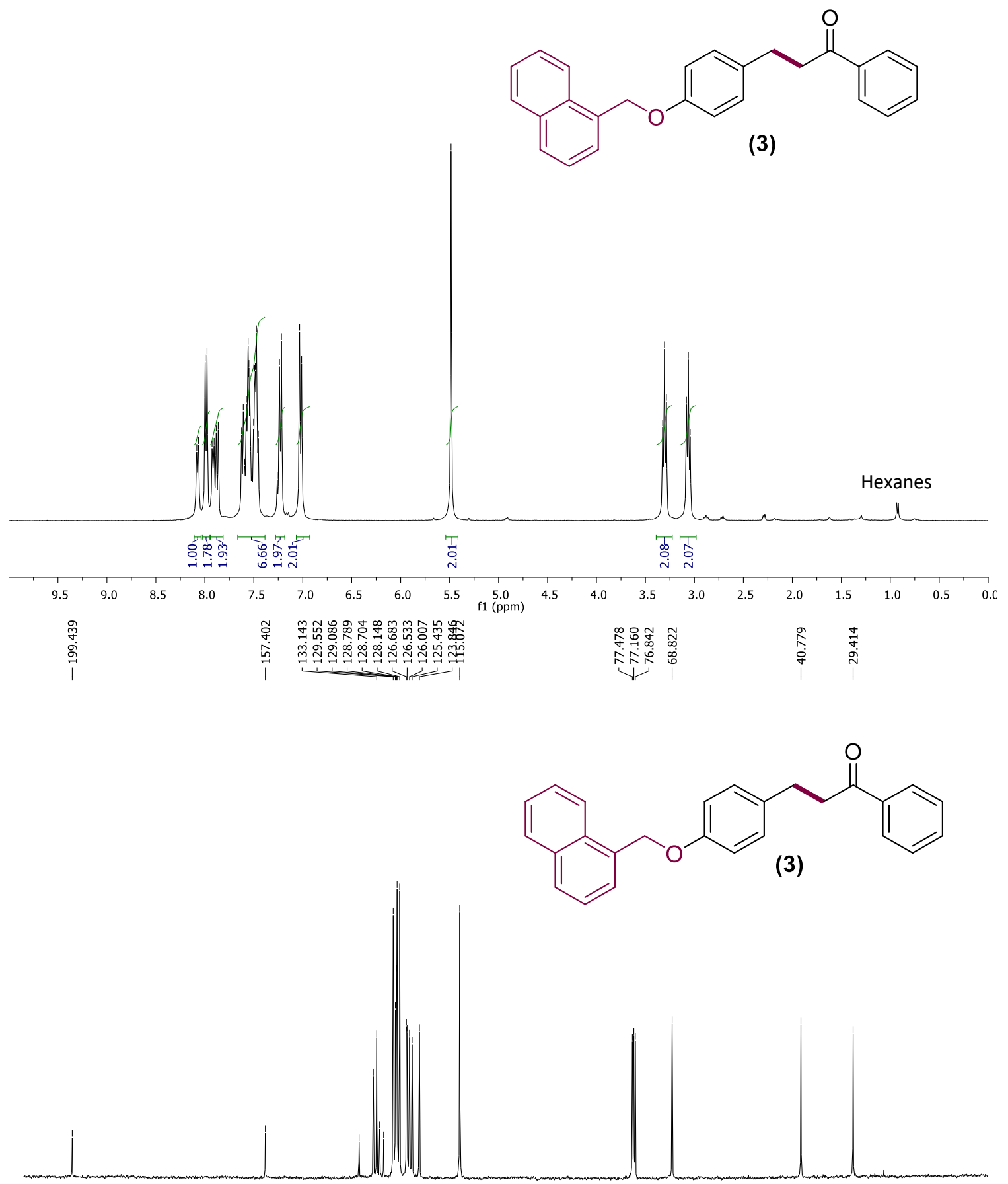

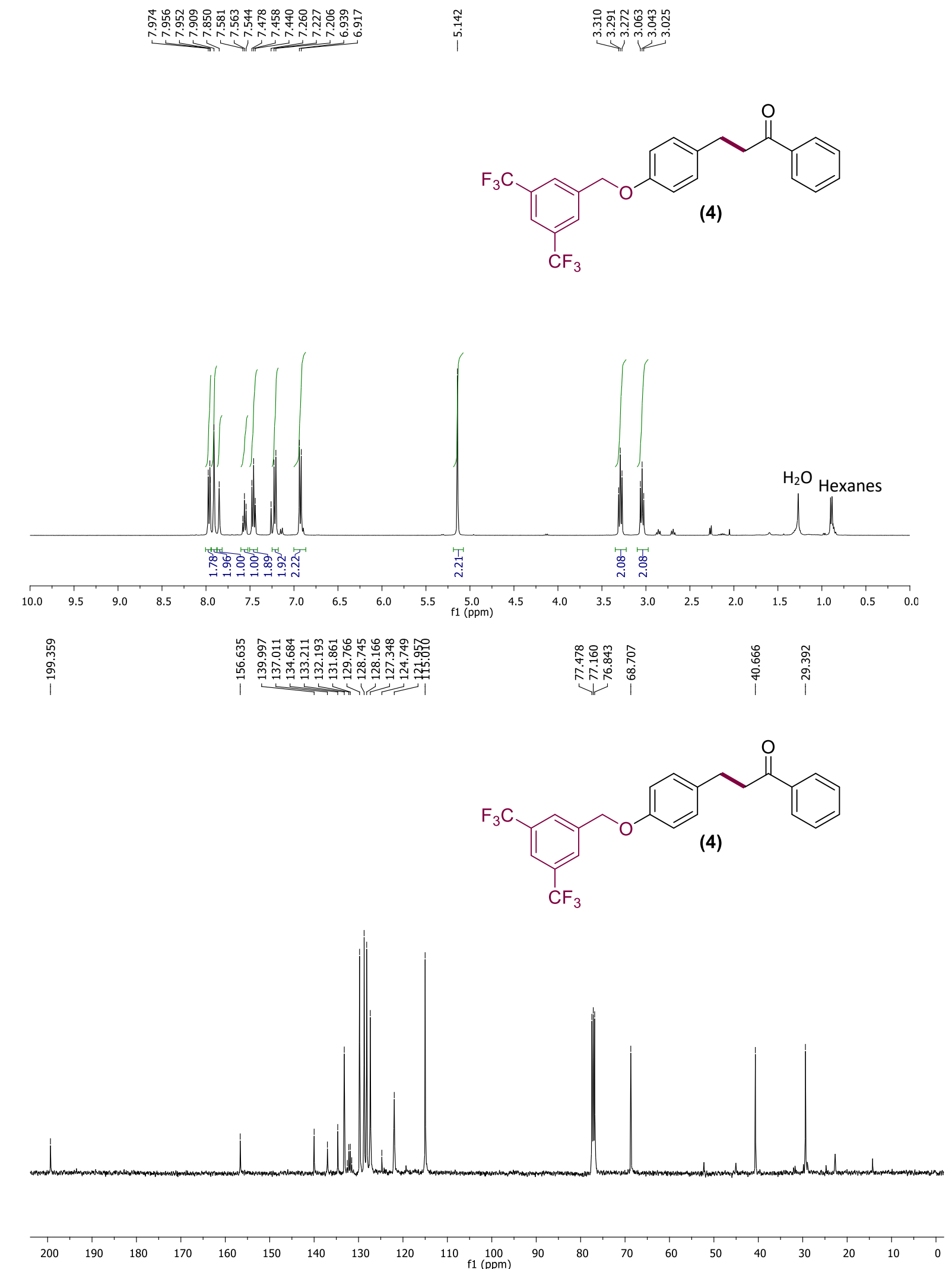


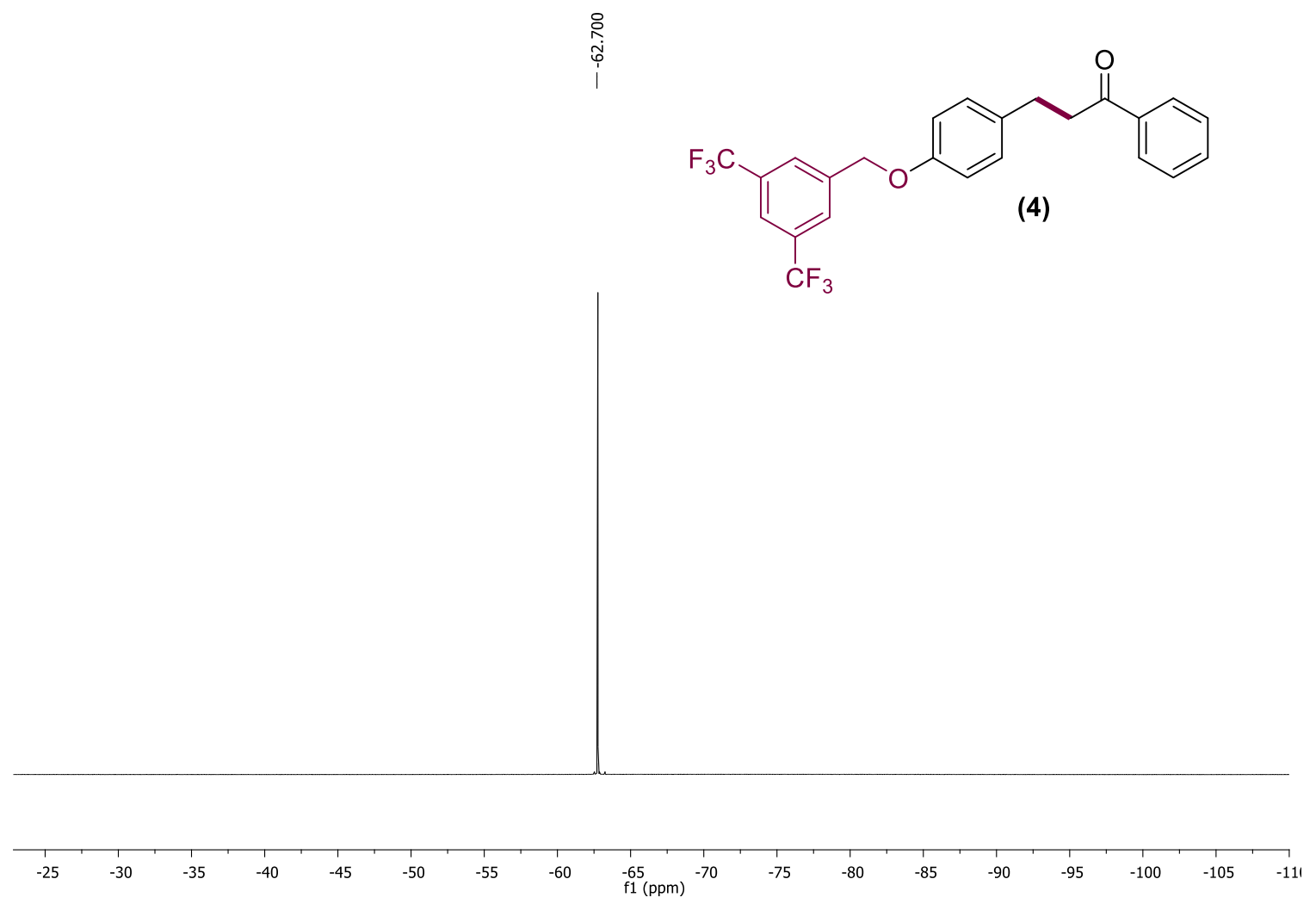



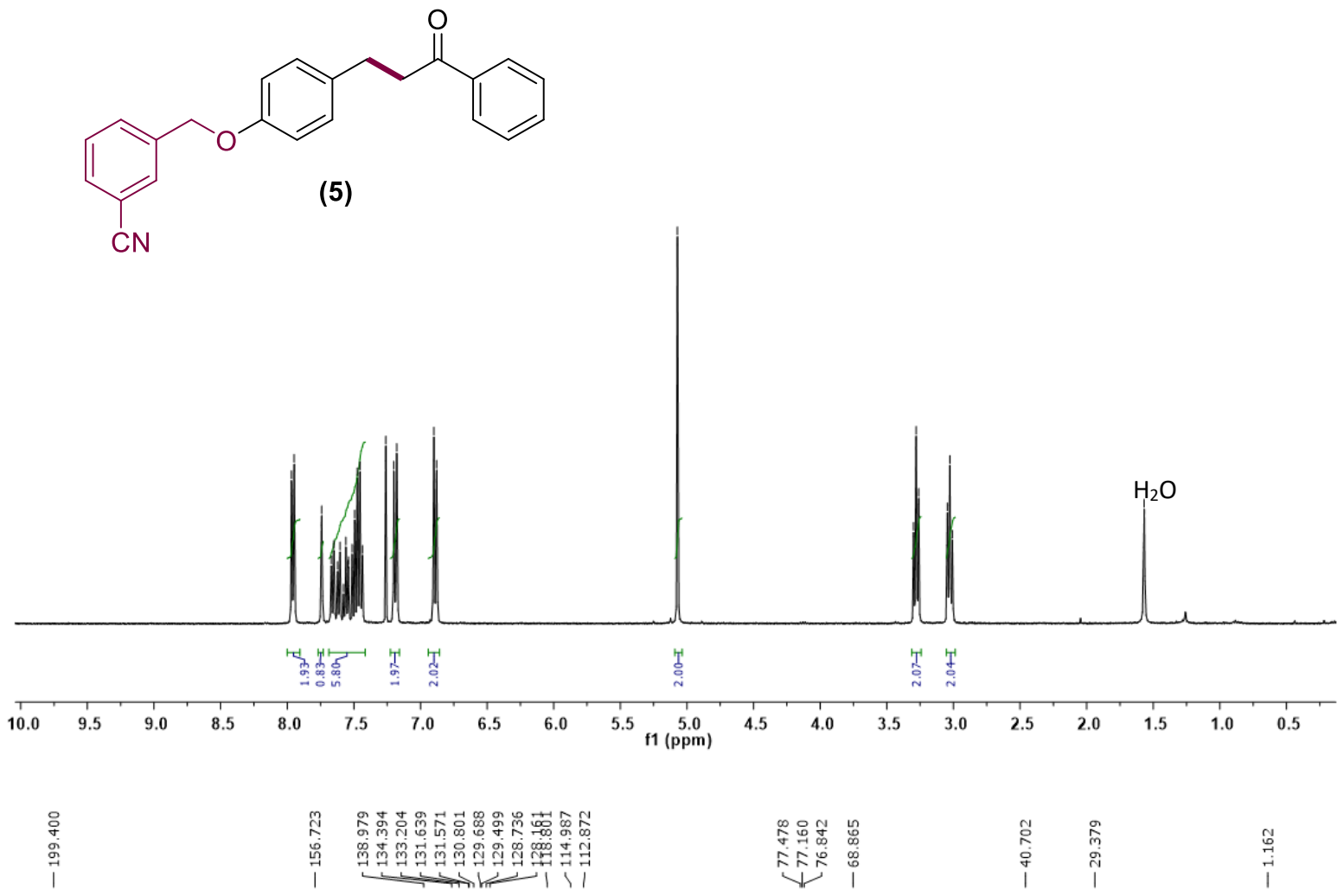<smiles>N#Cc1cccc(COc2ccc(CCC(=O)c3ccccc3)cc2)c1</smiles>
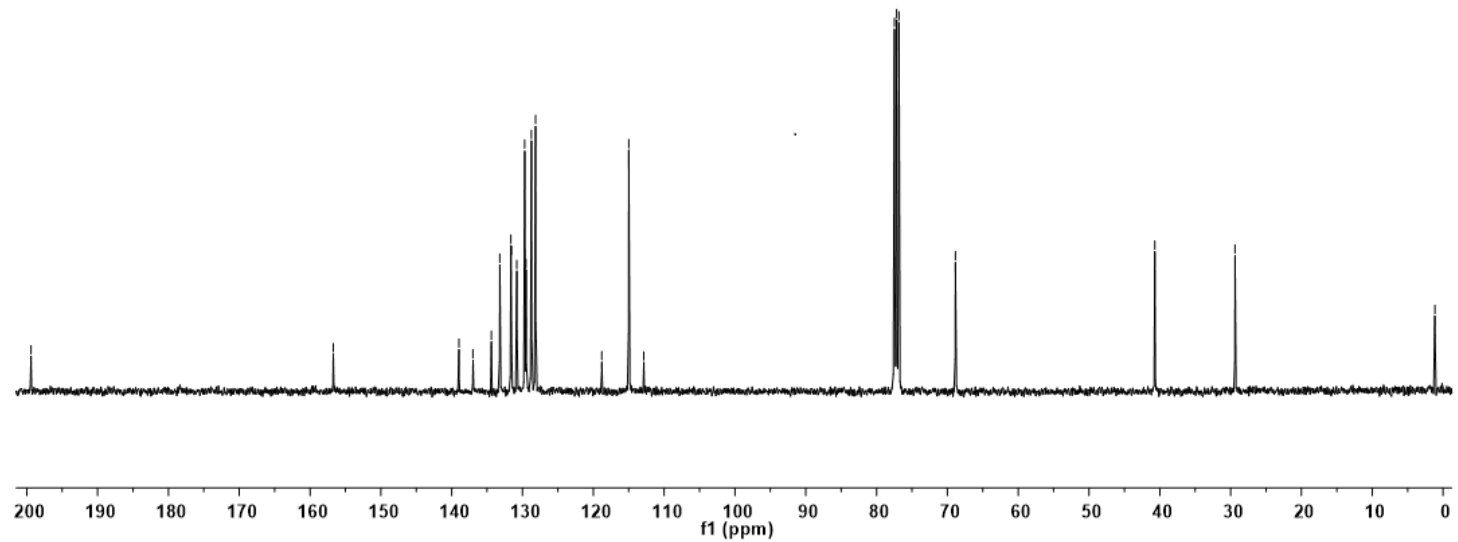


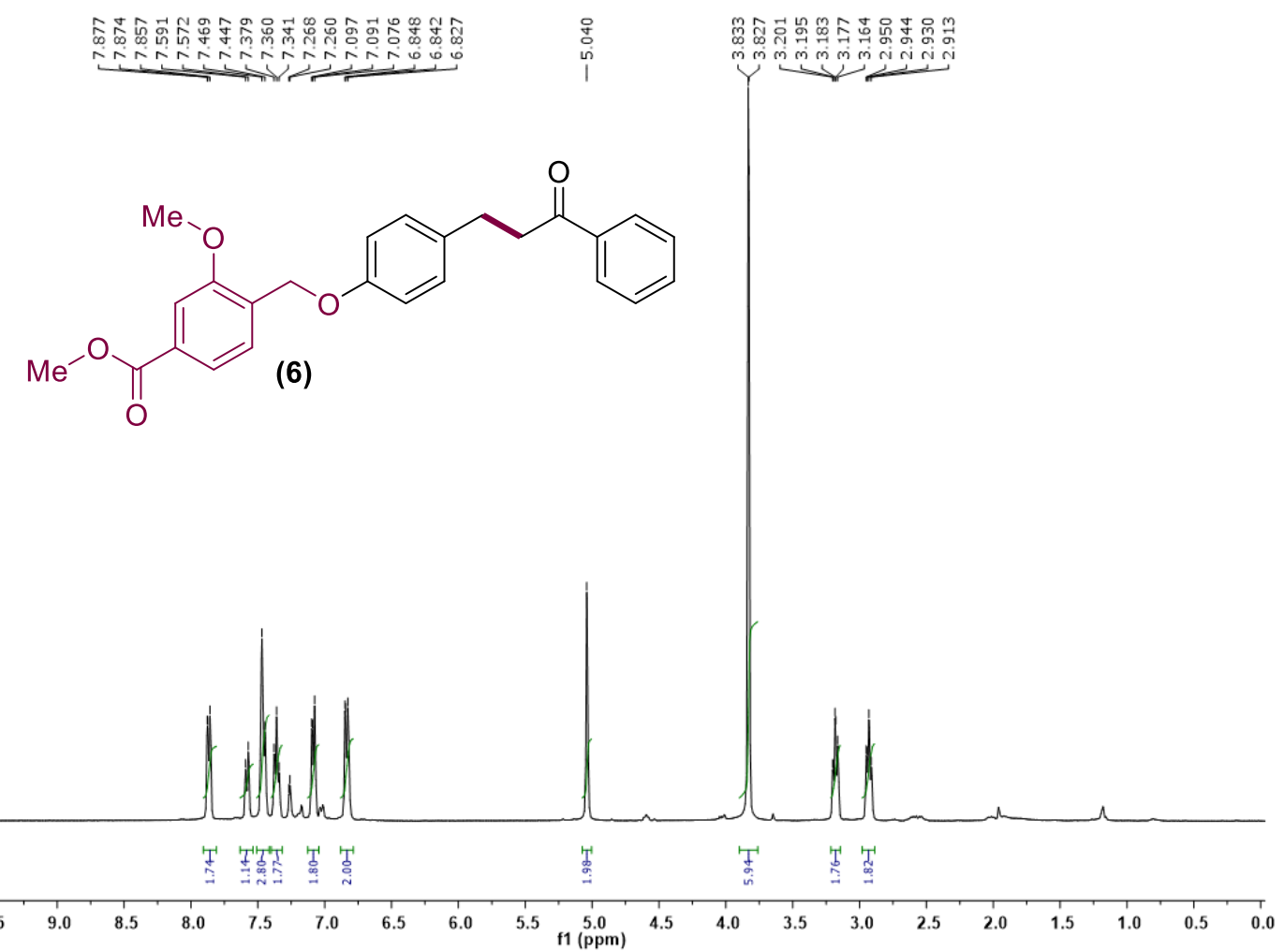

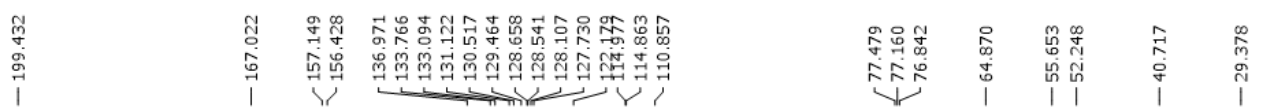
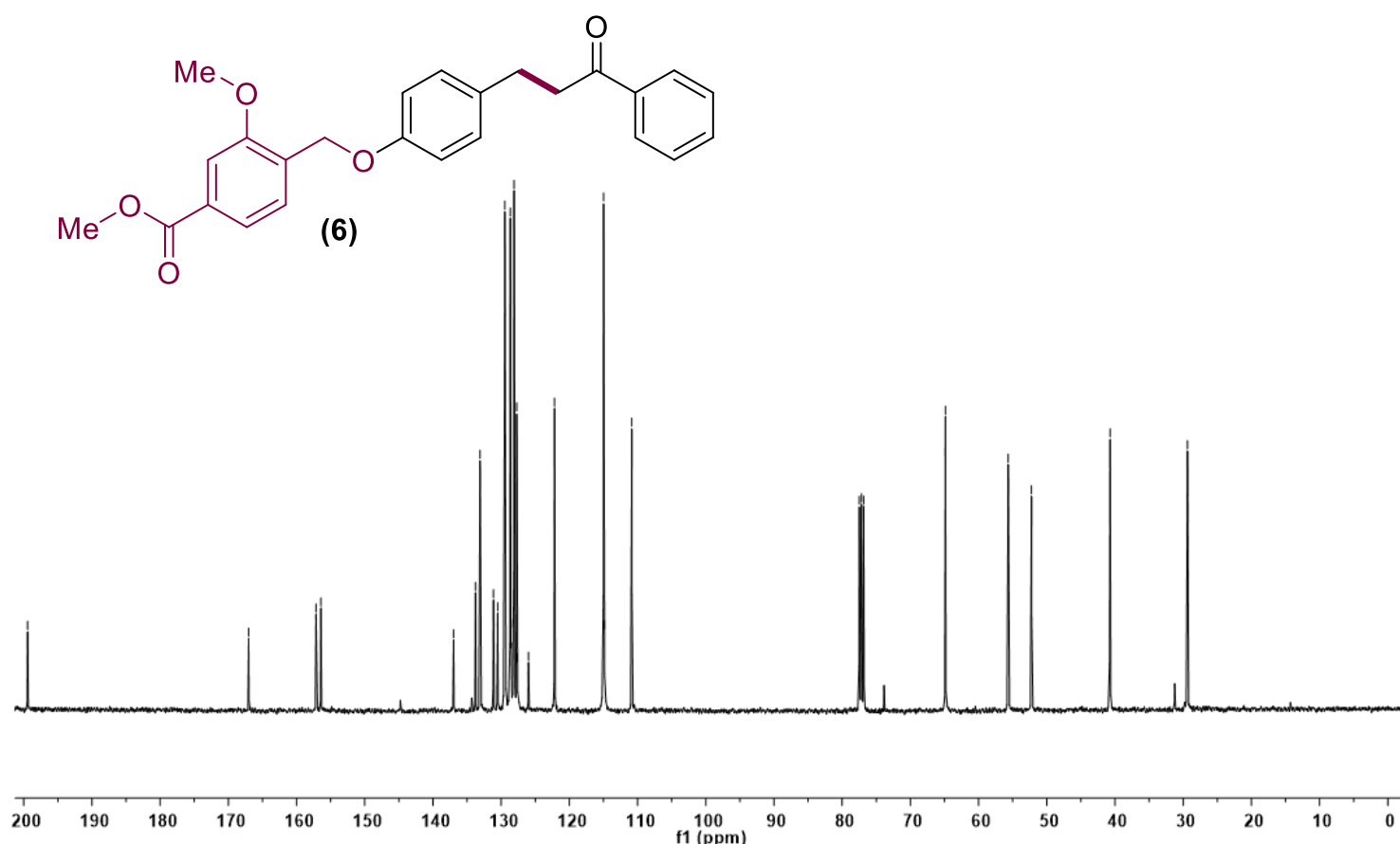
<smiles>O=C(CCc1ccc(OCc2ccccc2)cc1)c1ccc(-c2cccc3cccnc23)cc1</smiles>

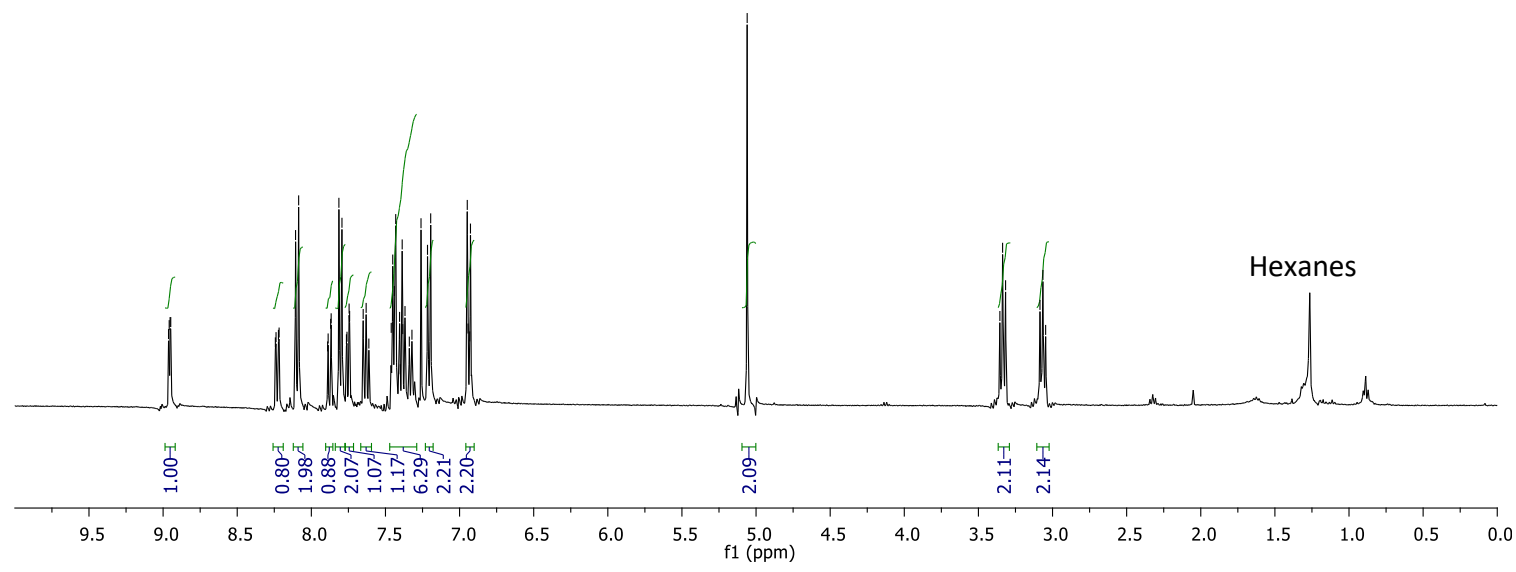

商

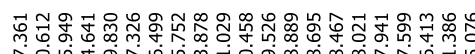

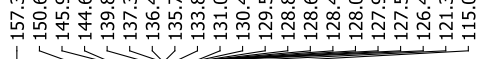<smiles>O=C(CCc1ccc(OCc2ccccc2)cc1)c1ccc(-c2cccc3cccnc23)cc1</smiles>
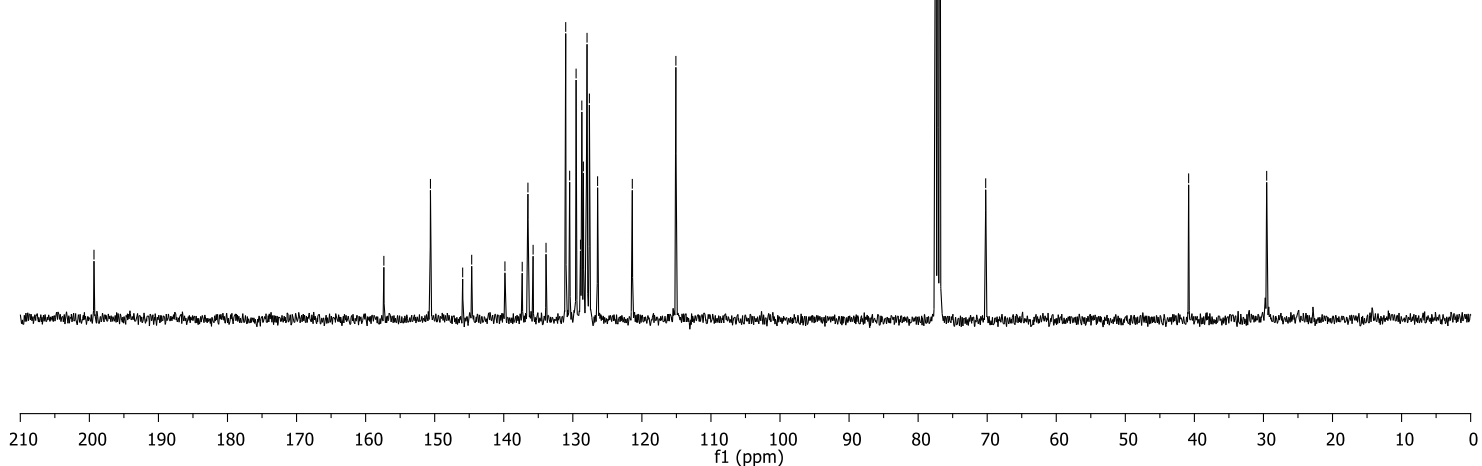

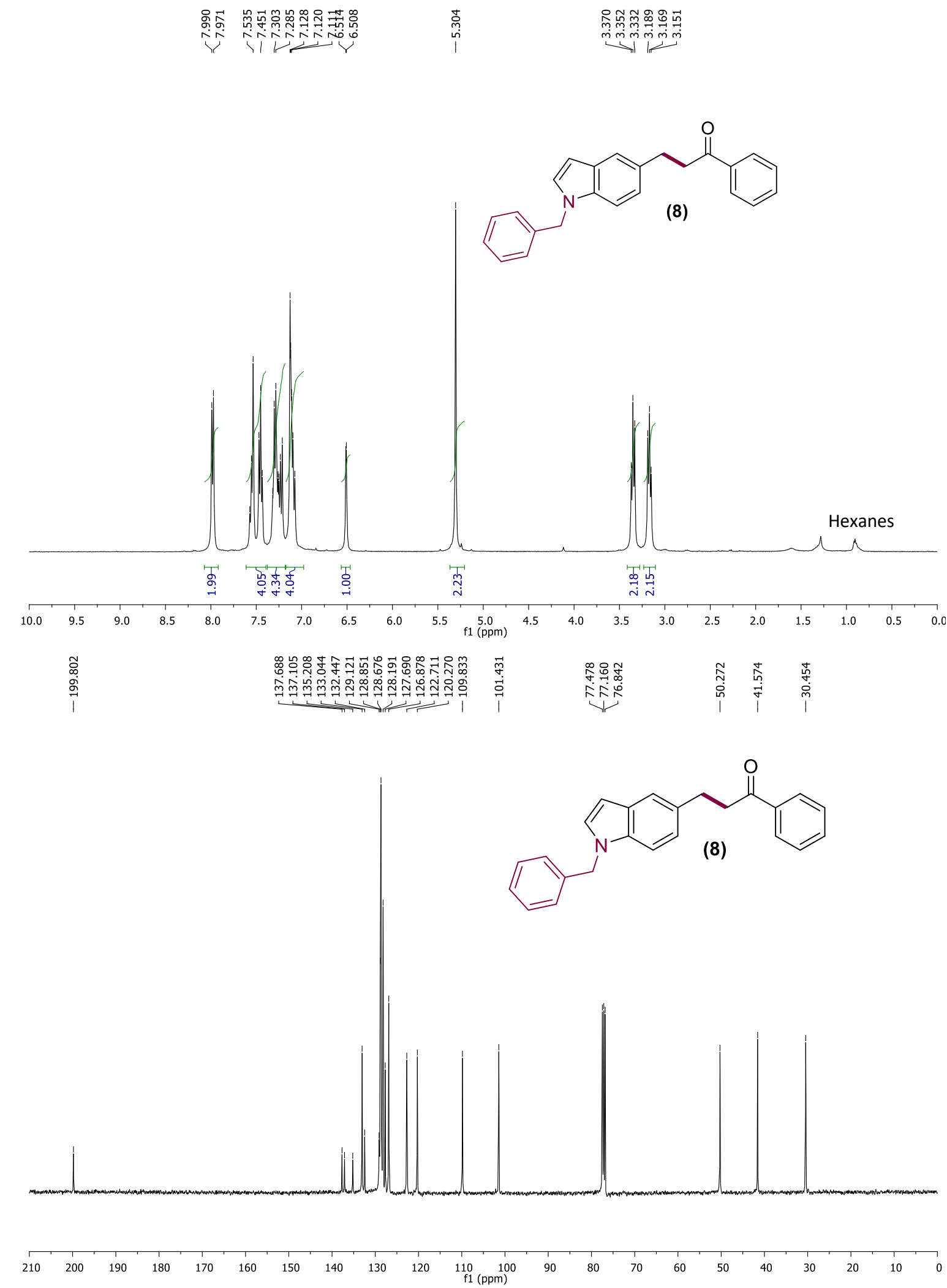

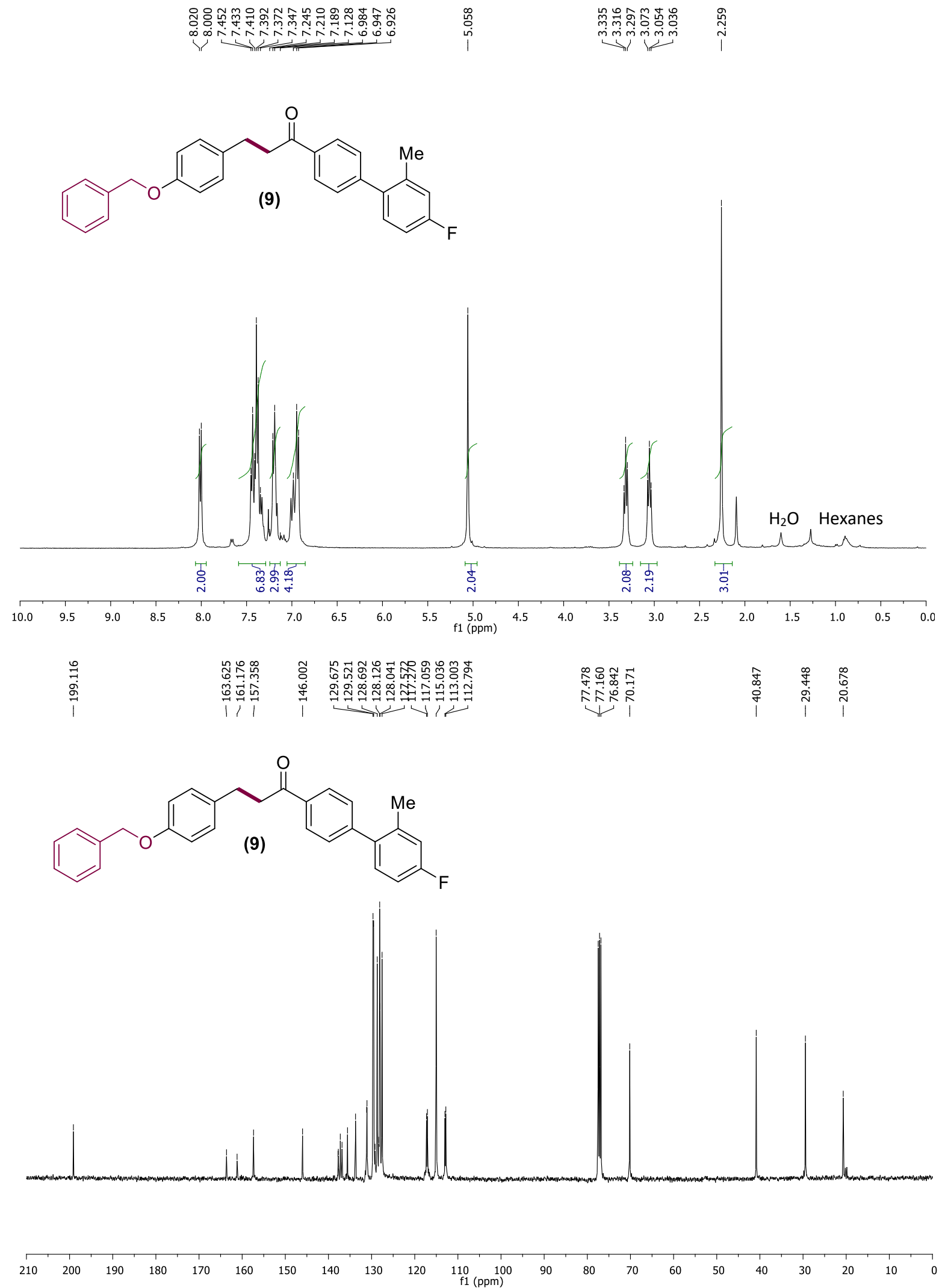


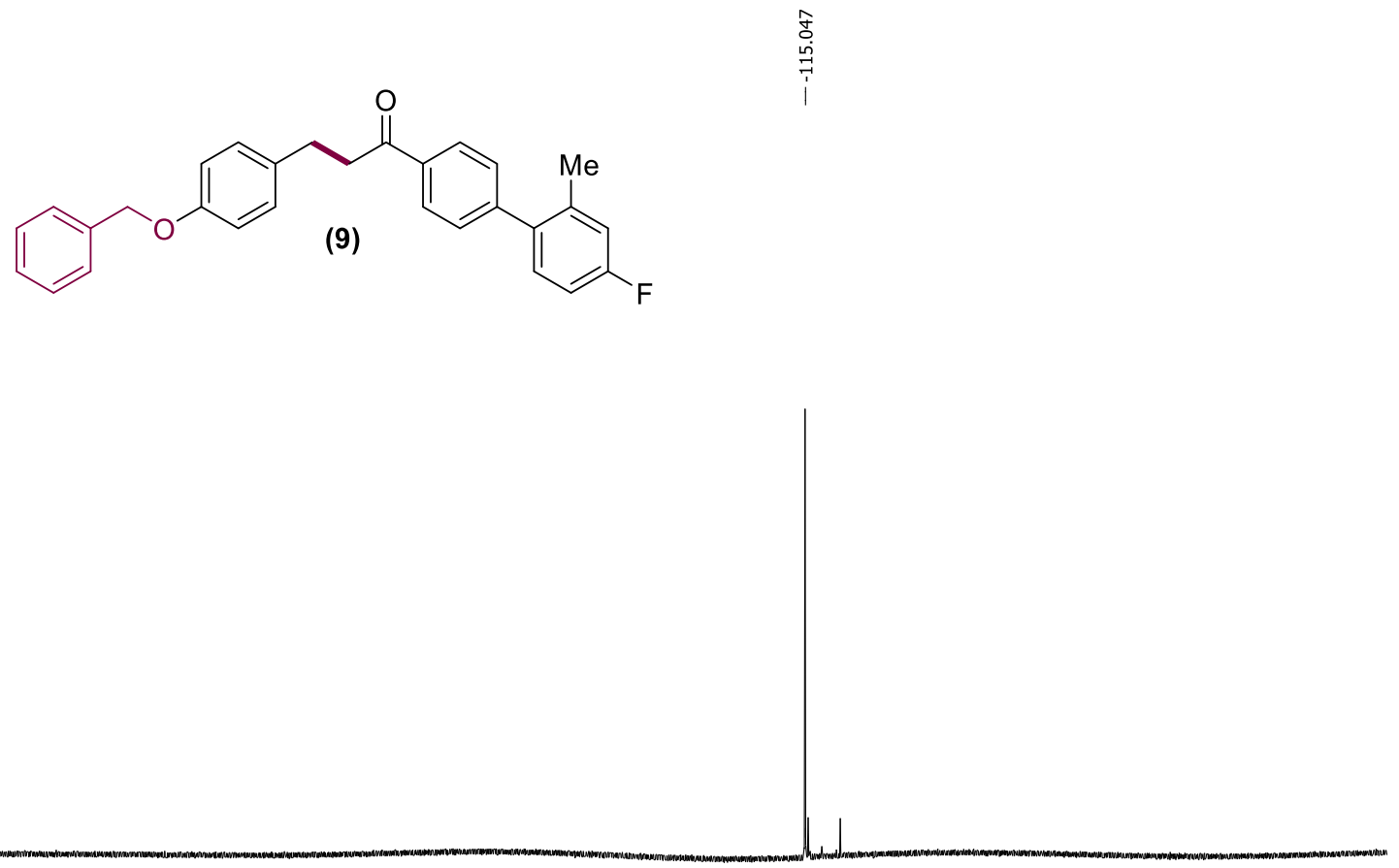

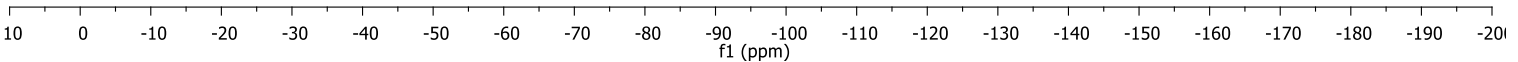


<smiles>CC(C)(C)c1ccc(COc2ccc(CCC(=O)c3ccccc3)cc2)cc1</smiles>

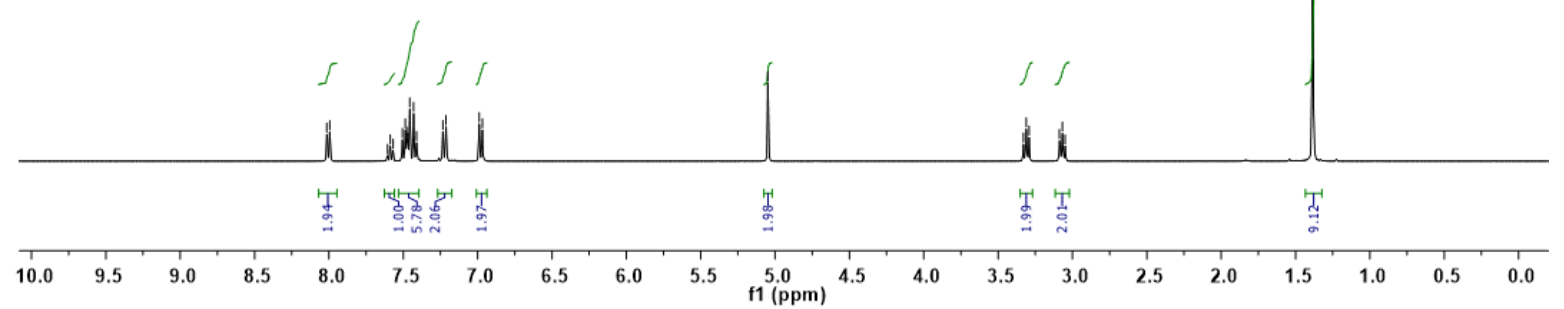

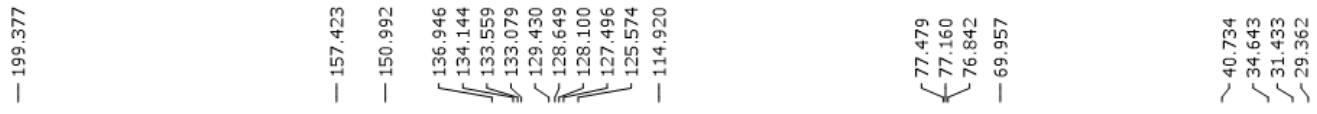<smiles>CC(C)(C)c1ccc(COc2ccc(CCC(=O)c3ccccc3)cc2)cc1</smiles>

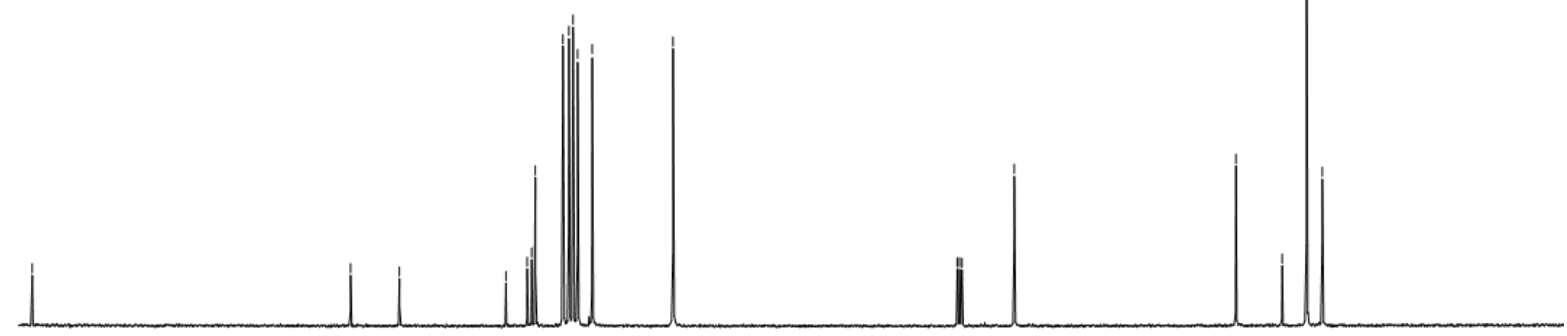



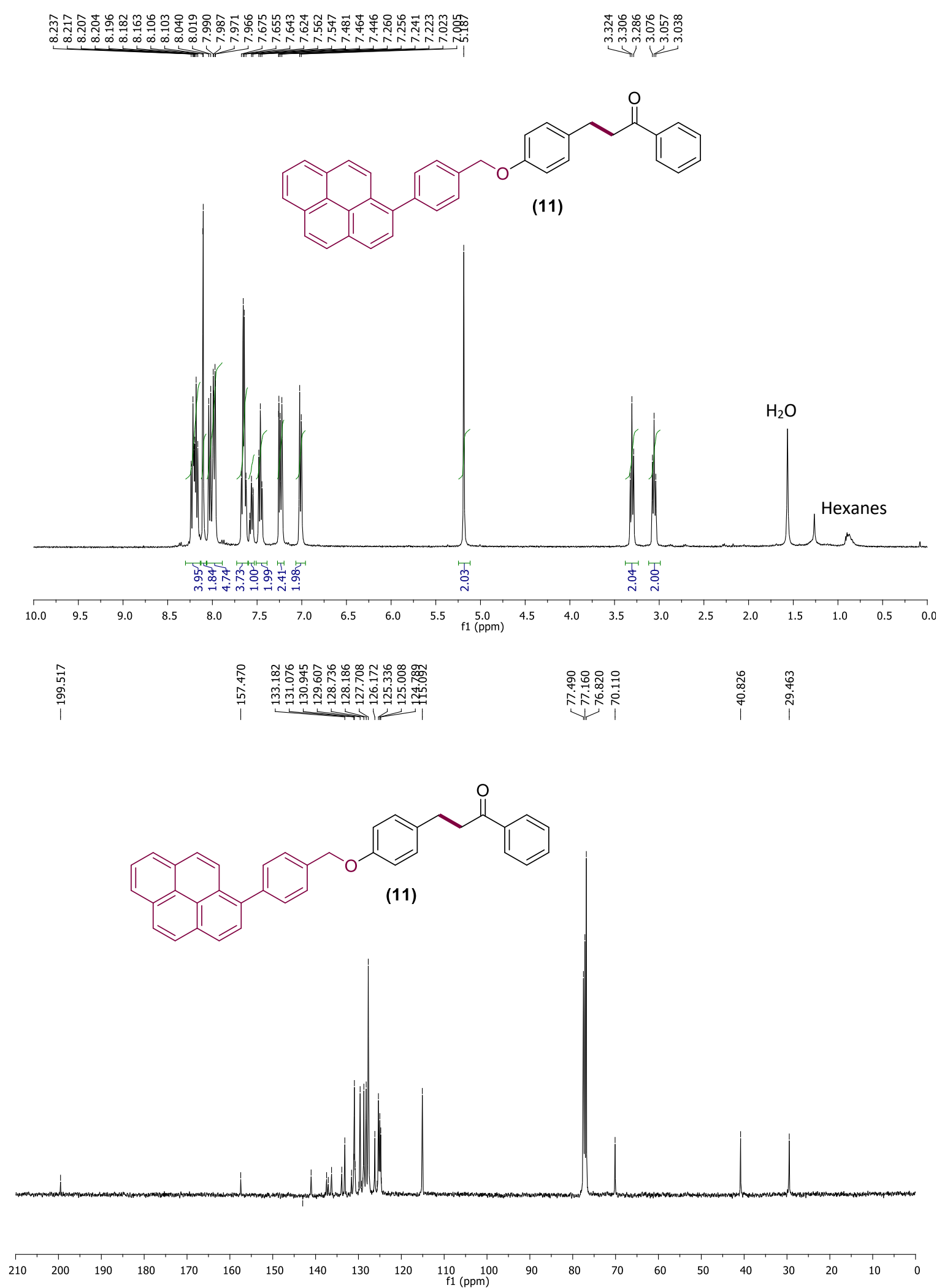

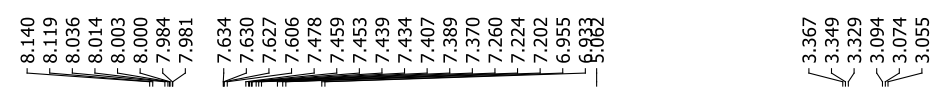<smiles>O=C(CCc1ccc(OCc2ccccc2)cc1)c1ccc(-c2cccc3c2oc2ccccc23)cc1</smiles>
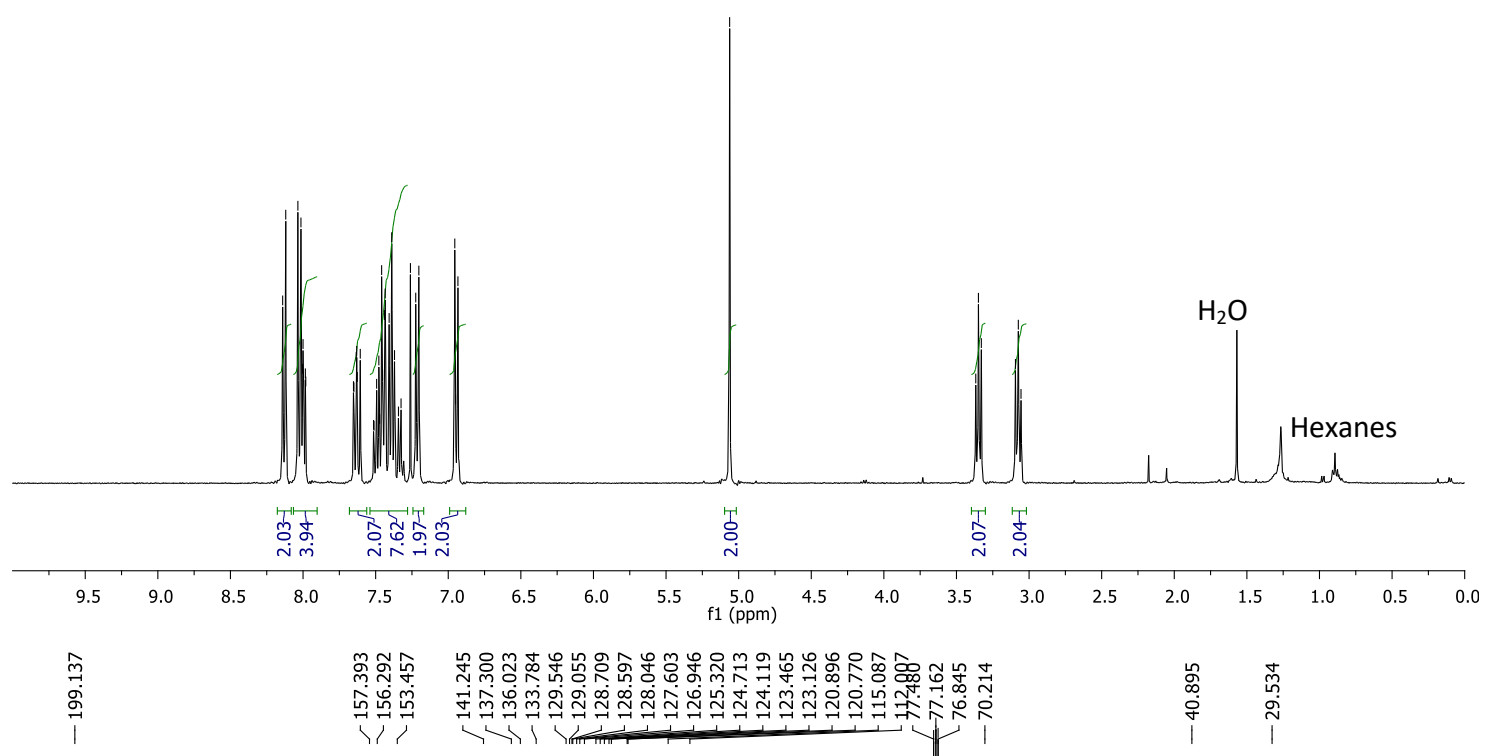<smiles>O=C(CCc1ccc(OCc2ccccc2)cc1)c1ccc(-c2cccc3c2oc2ccccc23)cc1</smiles>

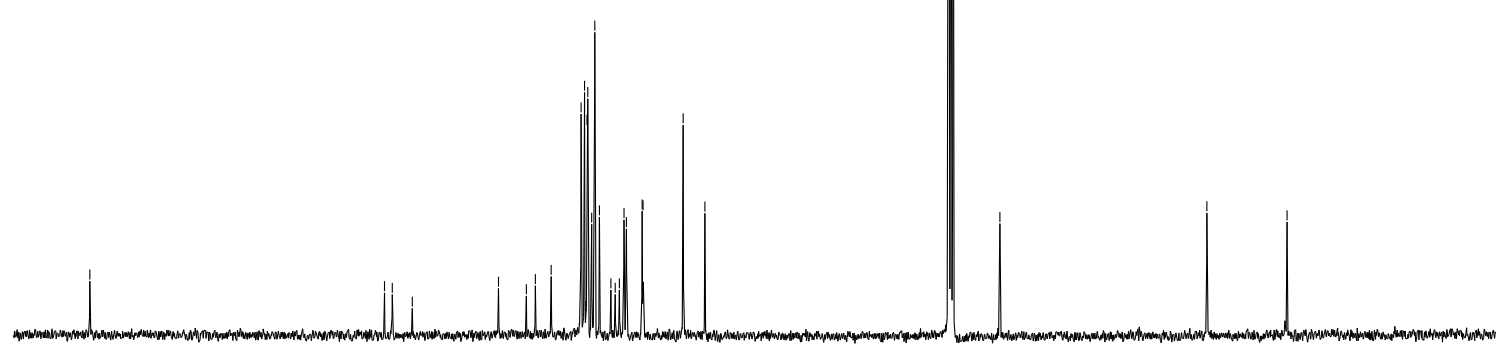



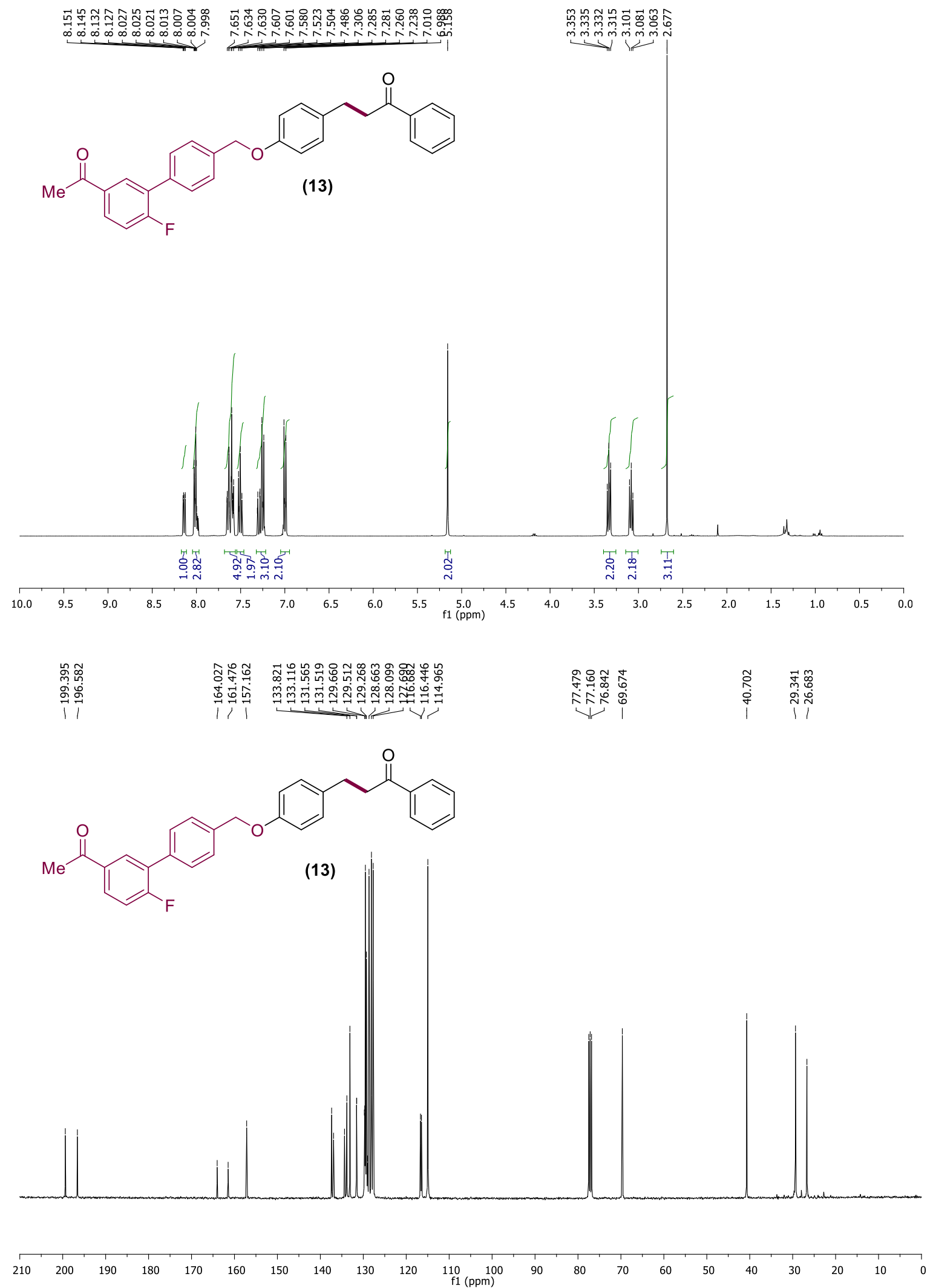


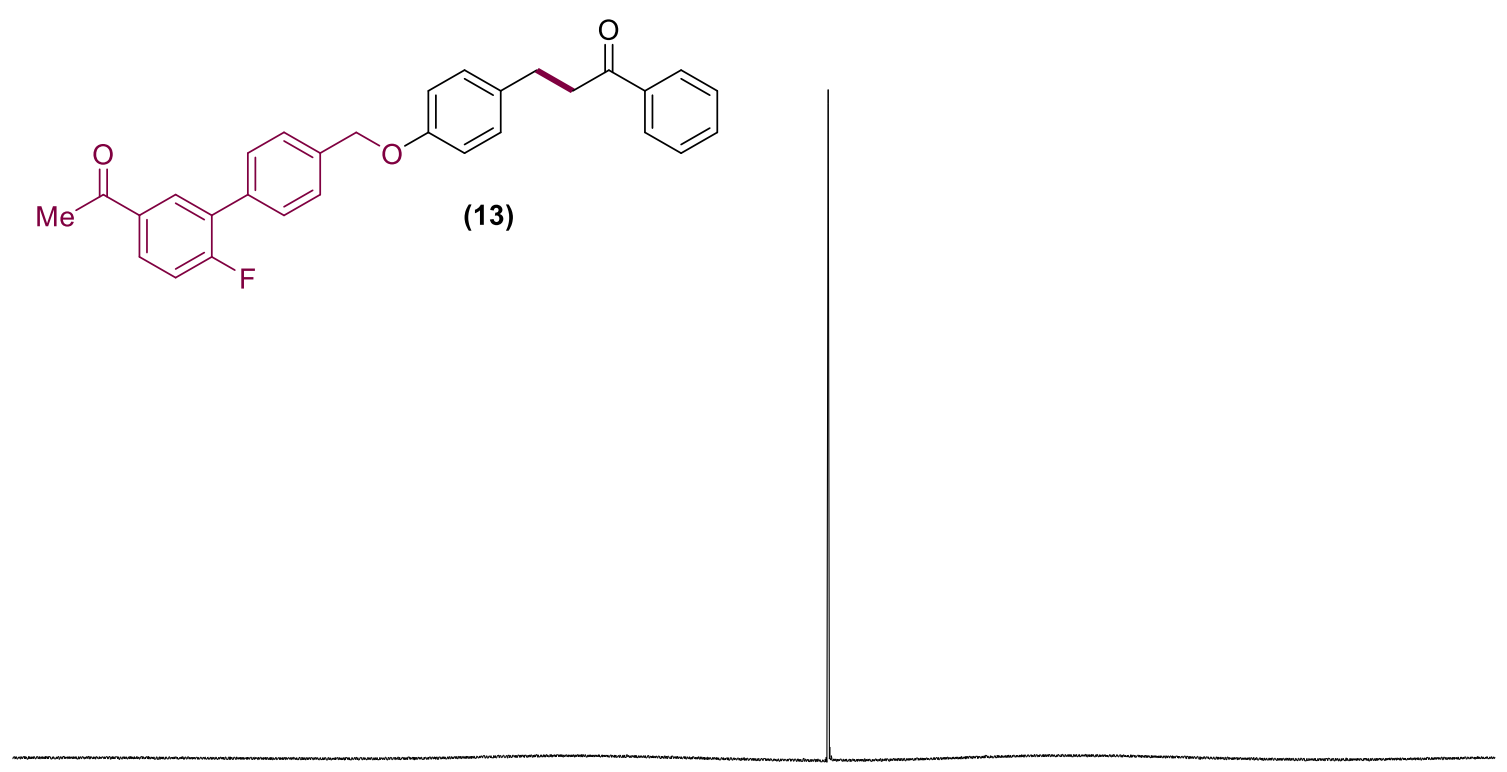

\begin{tabular}{lll}
\hline 0 & -10 & -20
\end{tabular}

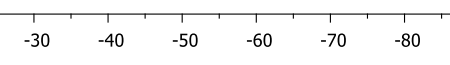
$\begin{array}{cc}-90 & -100 \\ & -100 \\ & (p p m)\end{array}$ 

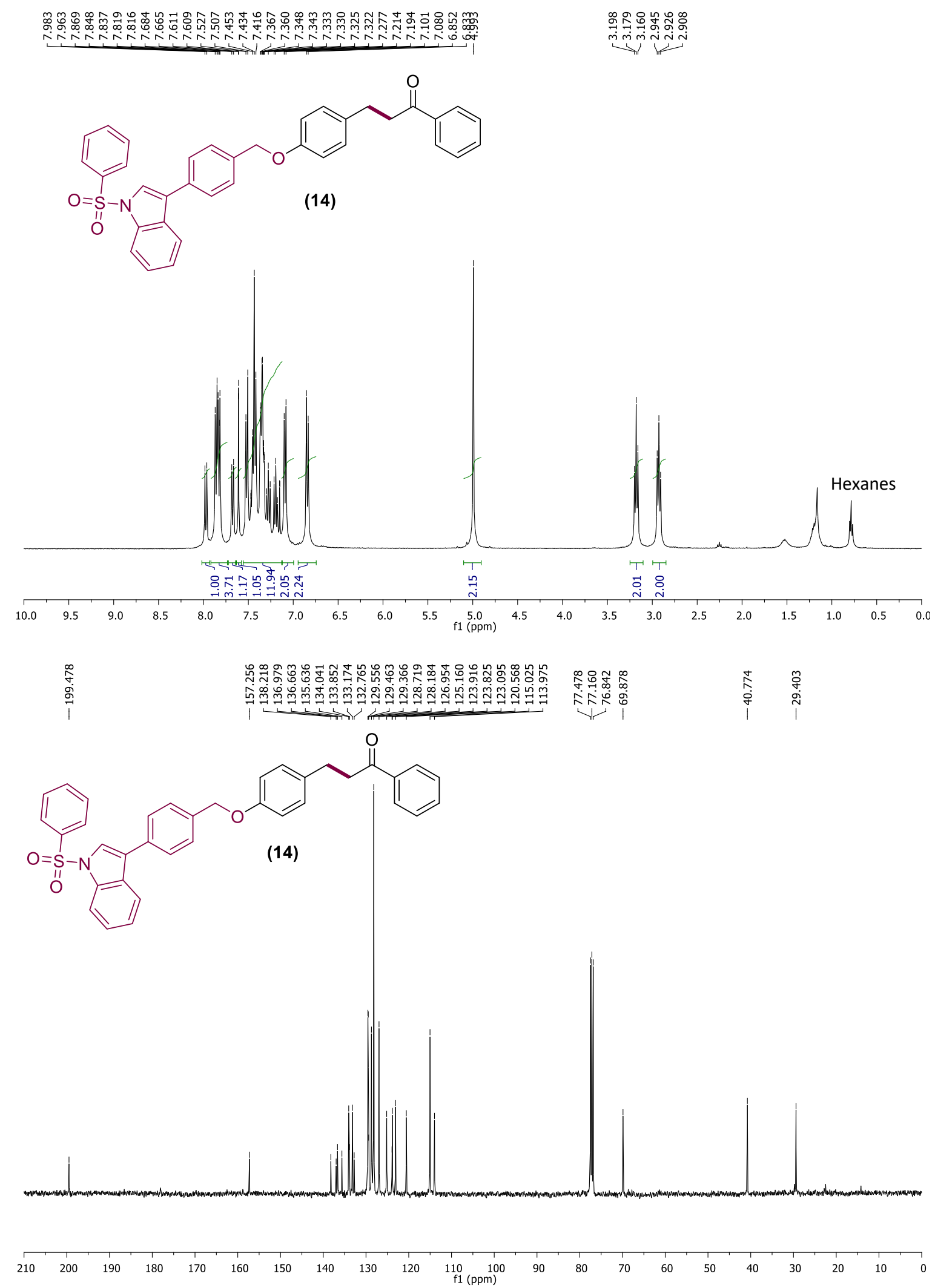


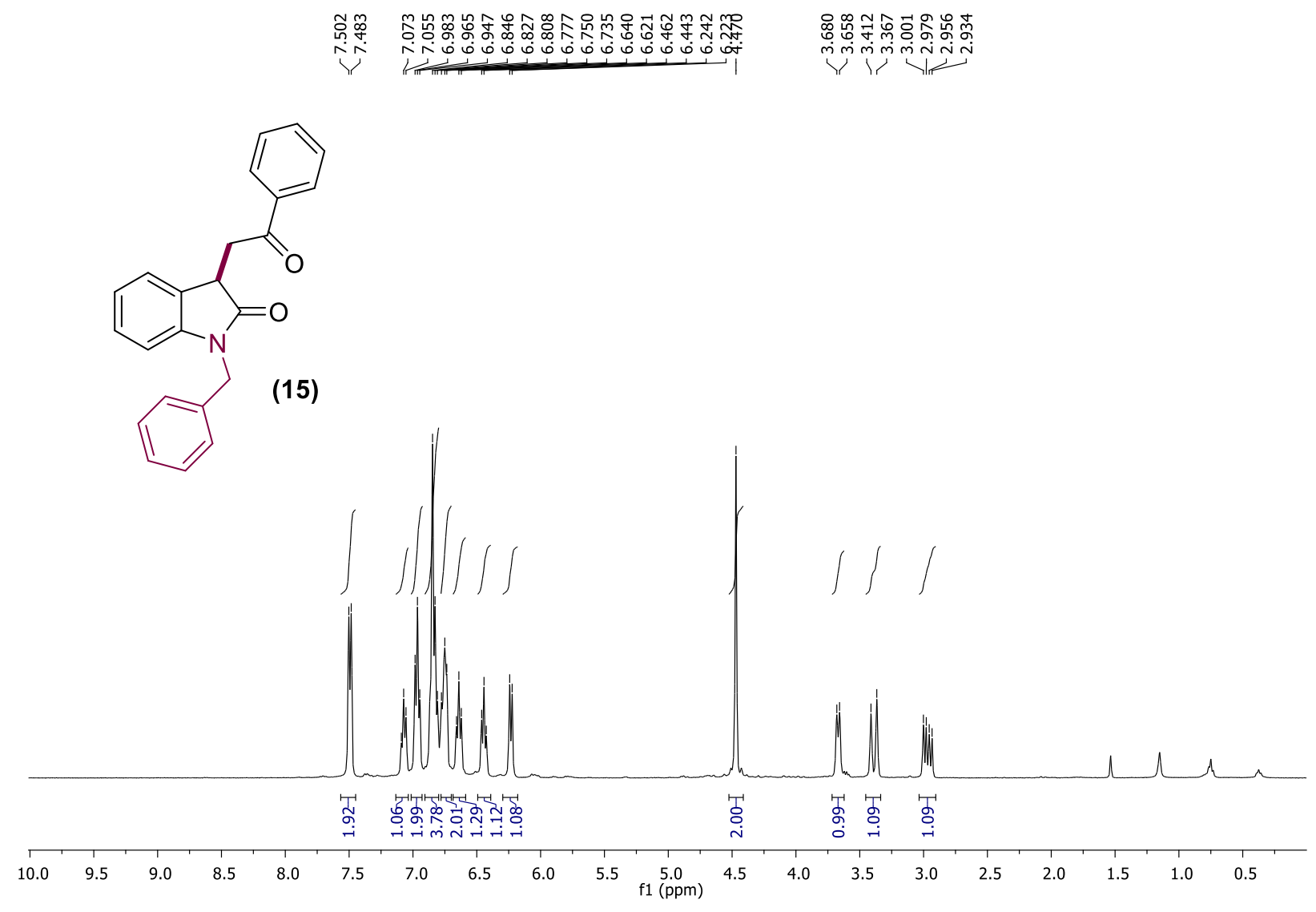



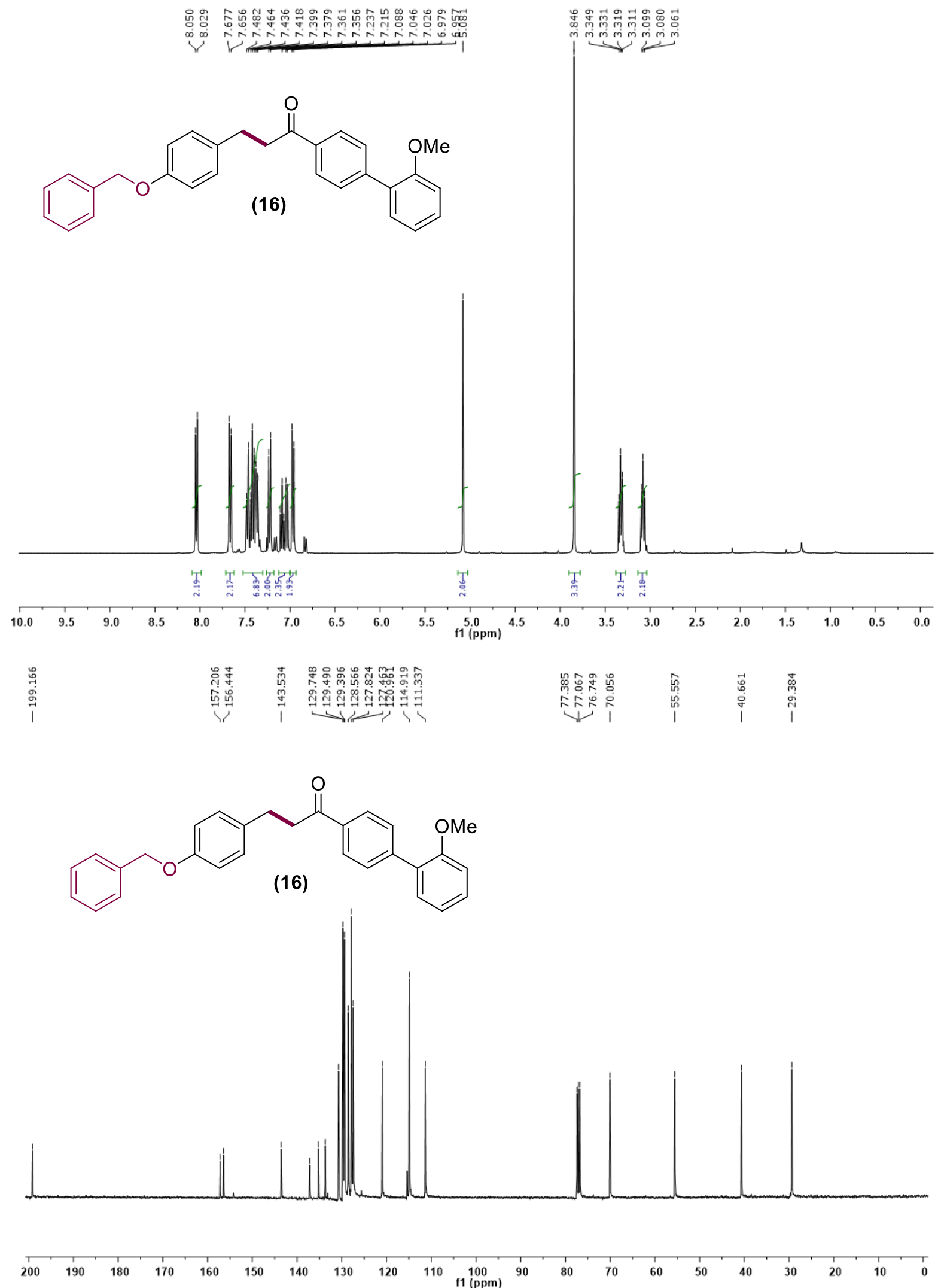


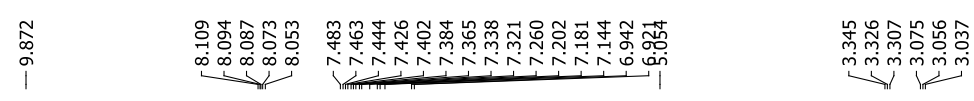<smiles>O=Cc1cc(F)ccc1-c1ccc(C(=O)CCc2ccc(OCc3ccccc3)cc2)cc1</smiles>
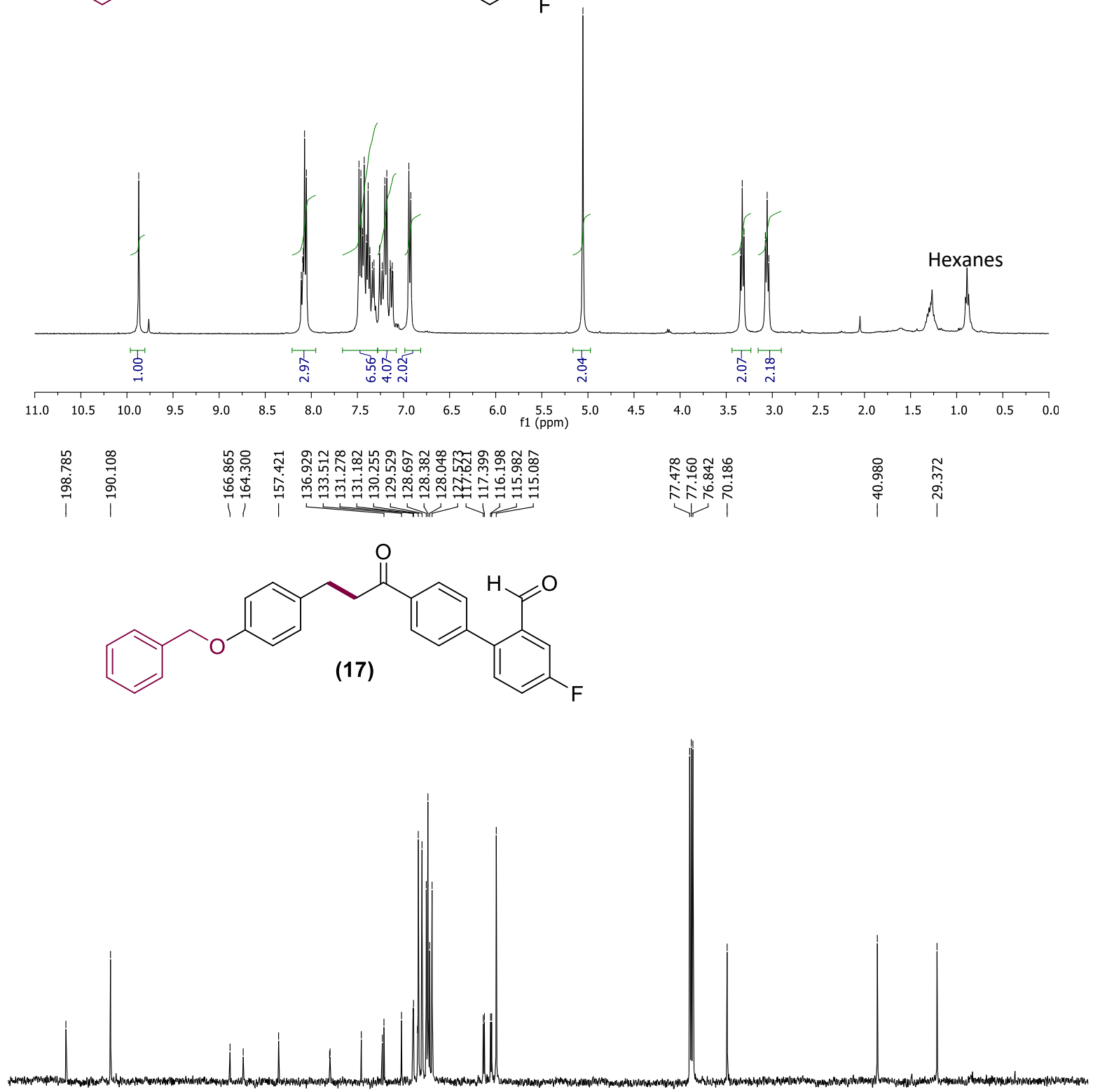

$\begin{array}{lllllllllllllllllllll}200 & 190 & 180 & 170 & 160 & 150 & 140 & 130 & 120 & 110 & 100 & 90 & 80 & 70 & 60 & 50 & 40 & 30 & 20 & 10 & 0\end{array}$ 


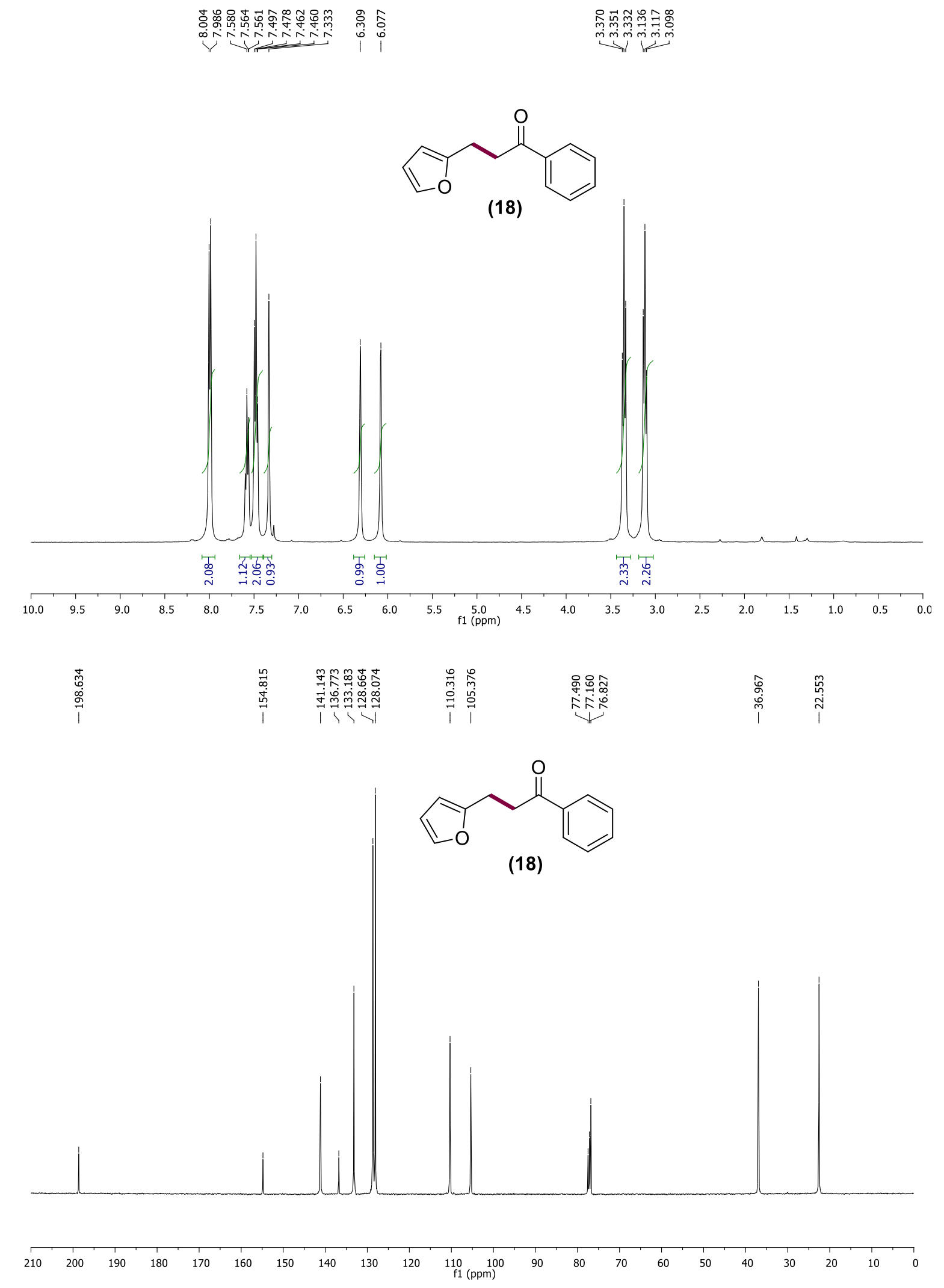




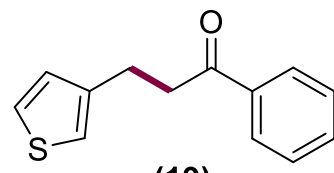

(19)

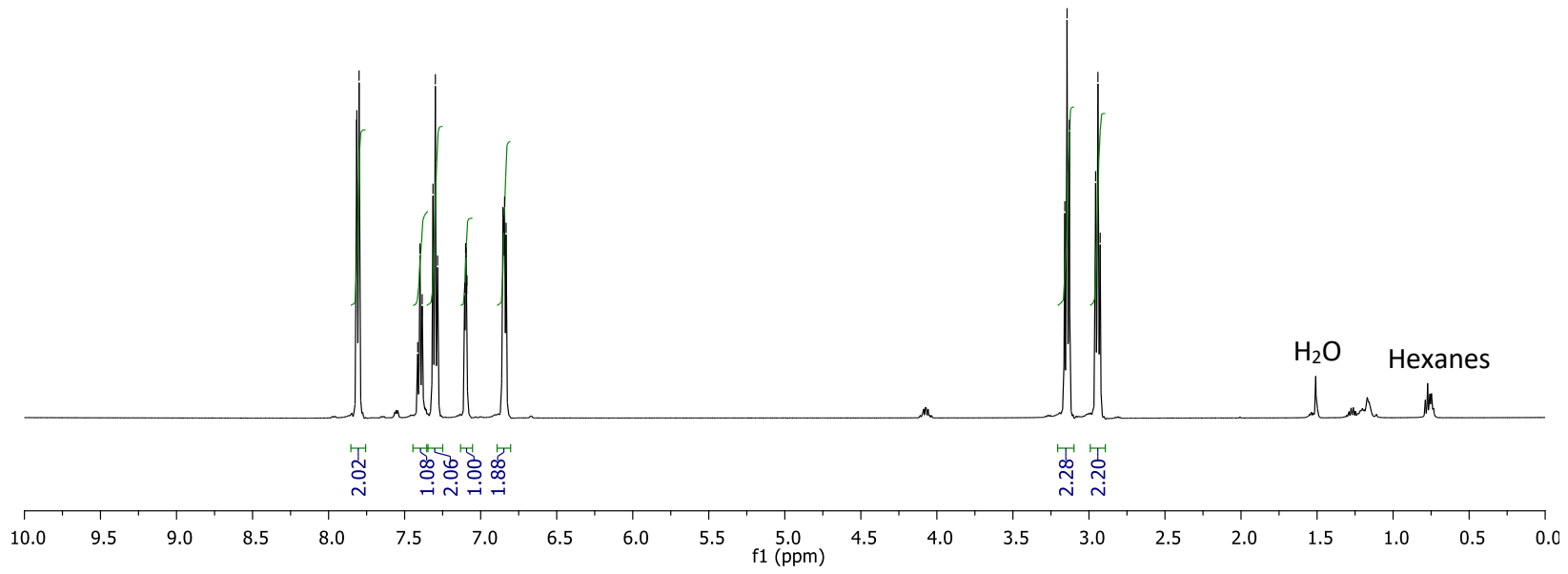




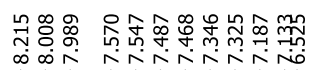

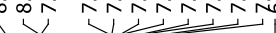

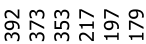

लें लें ले

$\rightarrow 1<$

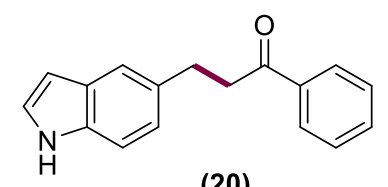

(20)

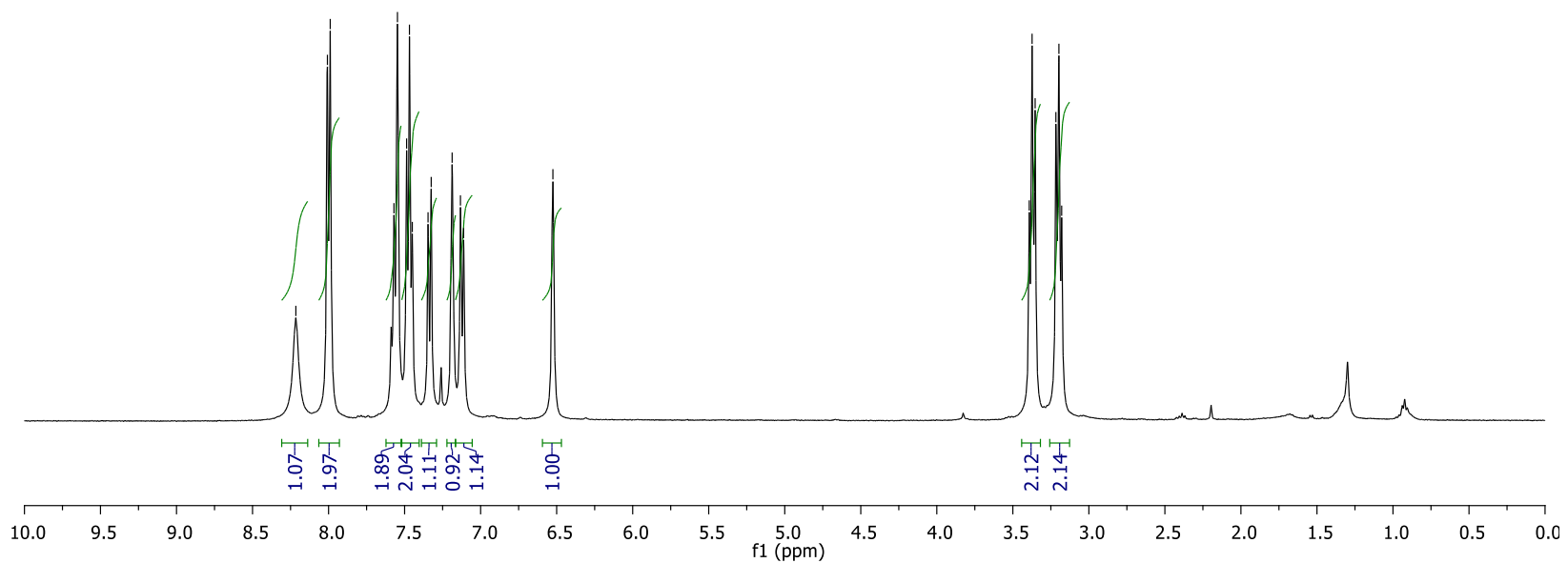



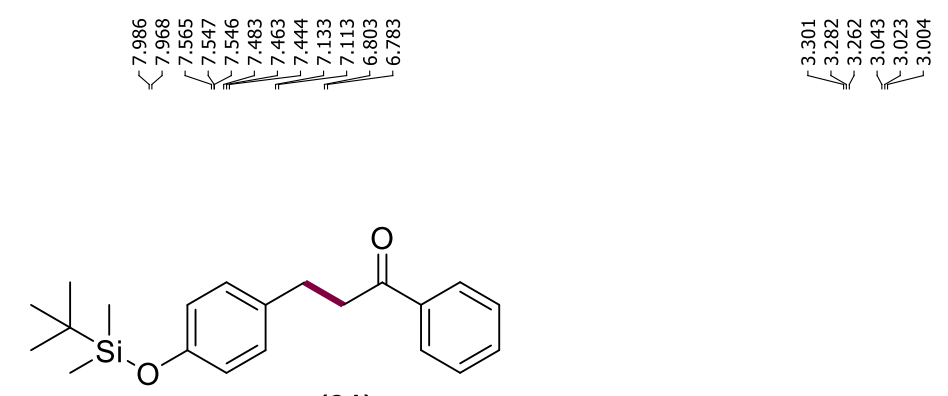

(21)

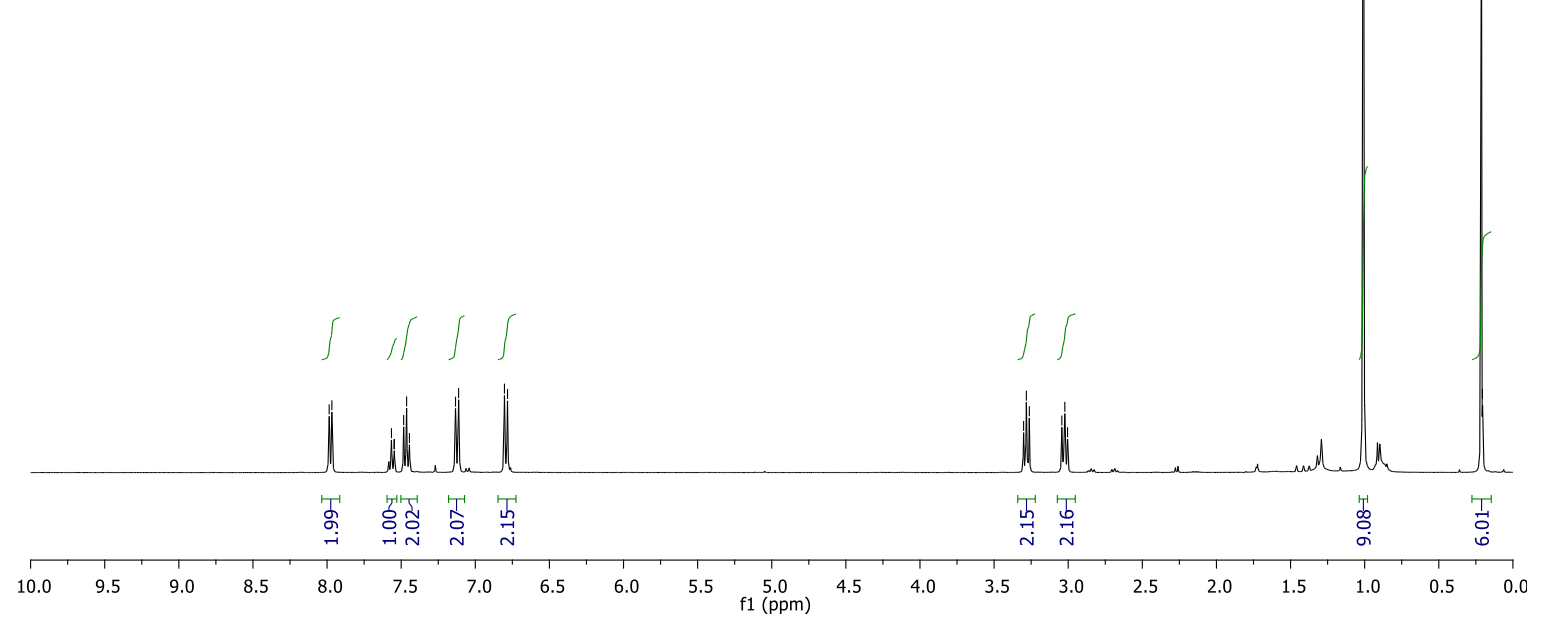

\begin{tabular}{|c|c|c|c|c|c|c|c|}
\hline $\begin{array}{l}\text { ले } \\
\text { గñ } \\
\text { ğ } \\
\text { । }\end{array}$ & $\begin{array}{l}\stackrel{n}{2} \\
0 \\
\dot{0} \\
\stackrel{n}{n} \\
1\end{array}$ & 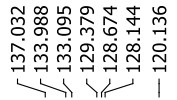 & 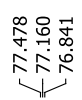 & $\begin{array}{c}\infty \\
\infty \\
\stackrel{\infty}{q} \\
\dot{q} \\
\mid\end{array}$ & 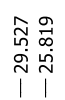 & 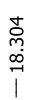 & 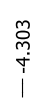 \\
\hline
\end{tabular}<smiles>CC(C)(C)[Si](C)(C)Oc1ccc(CCC(=O)c2ccccc2)cc1</smiles>

(21)
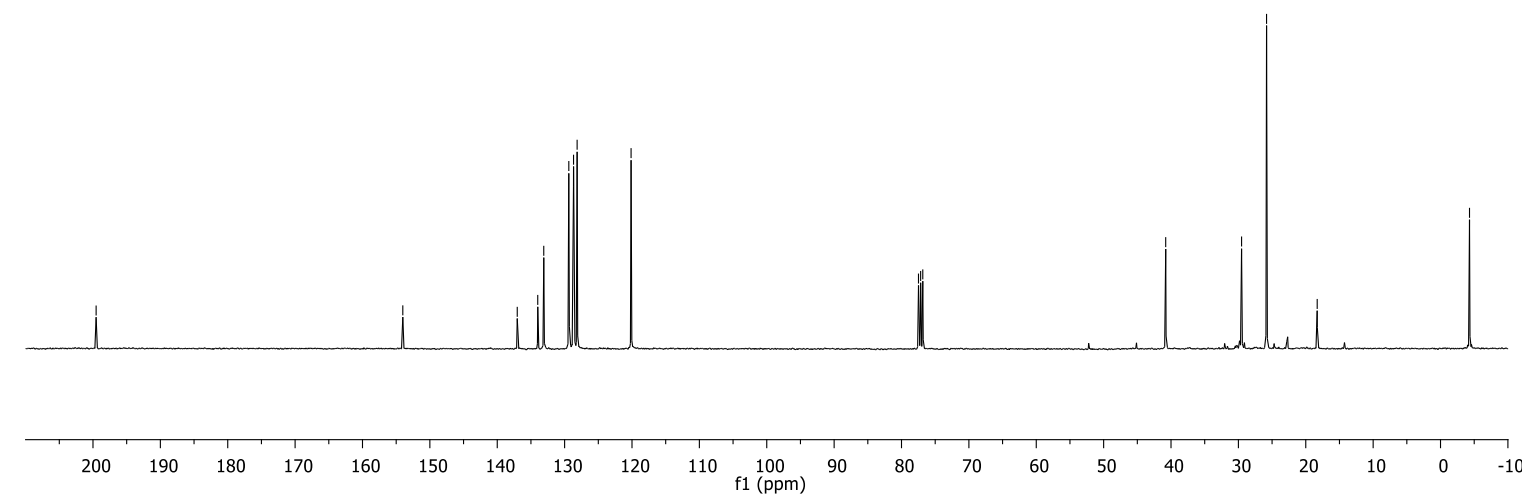
<smiles>Cc1ccc(S(=O)(=O)Oc2ccc(CCC(=O)c3ccccc3)cc2)cc1</smiles>

$\mathrm{H}_{2} \mathrm{O}$

Hexanes

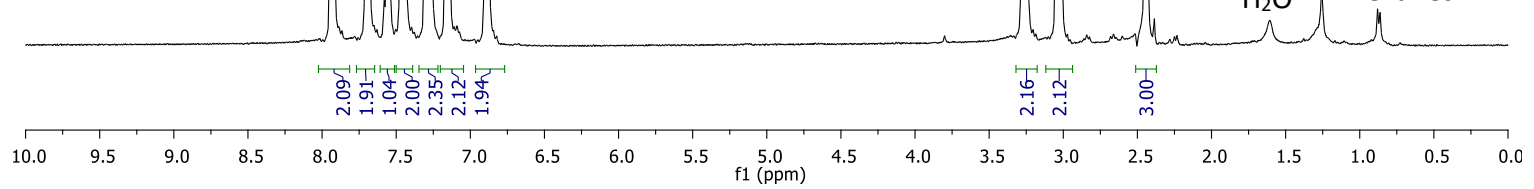<smiles>Cc1ccc(S(=O)(=O)Oc2ccc(CCC(=O)c3ccccc3)cc2)cc1</smiles>

(22)

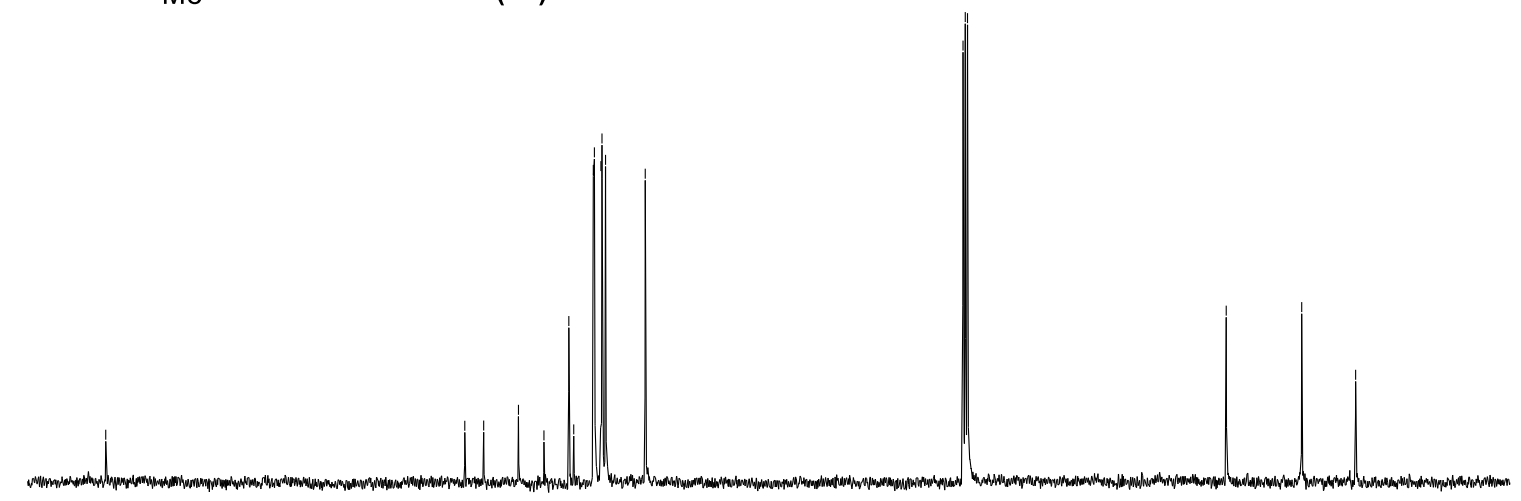



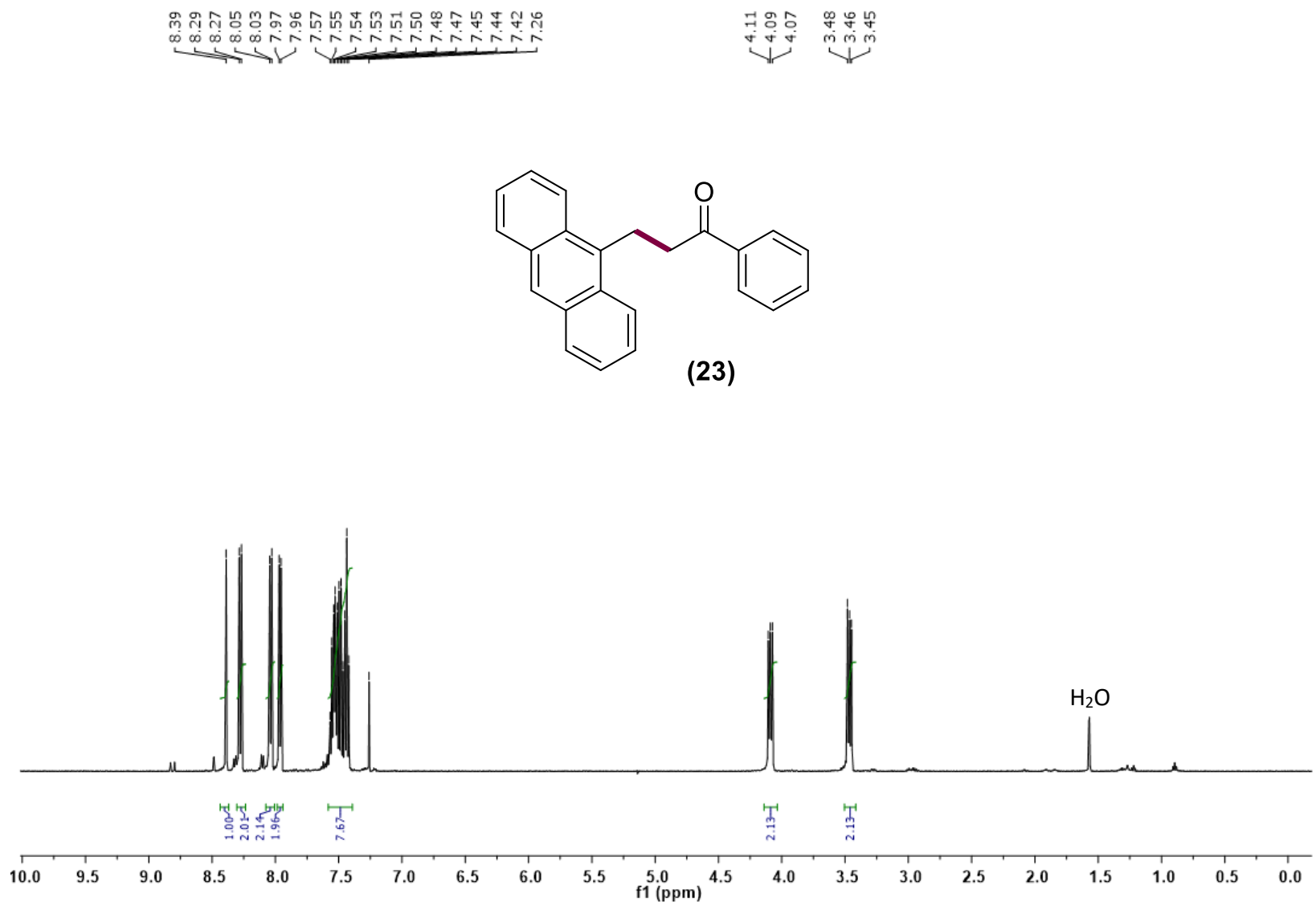


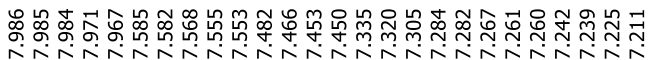

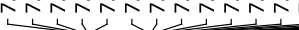<smiles>O=C(CCc1ccccc1)c1ccccc1</smiles>

(24)

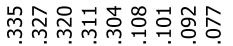

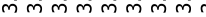

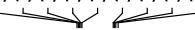

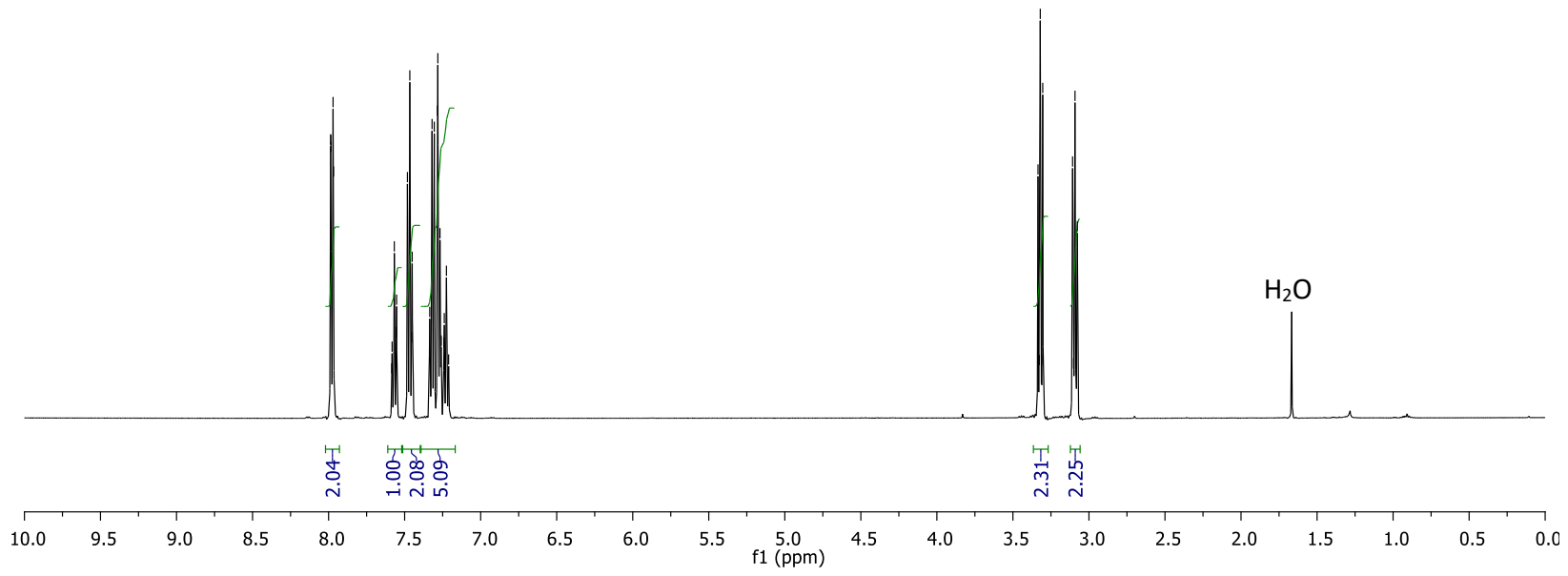



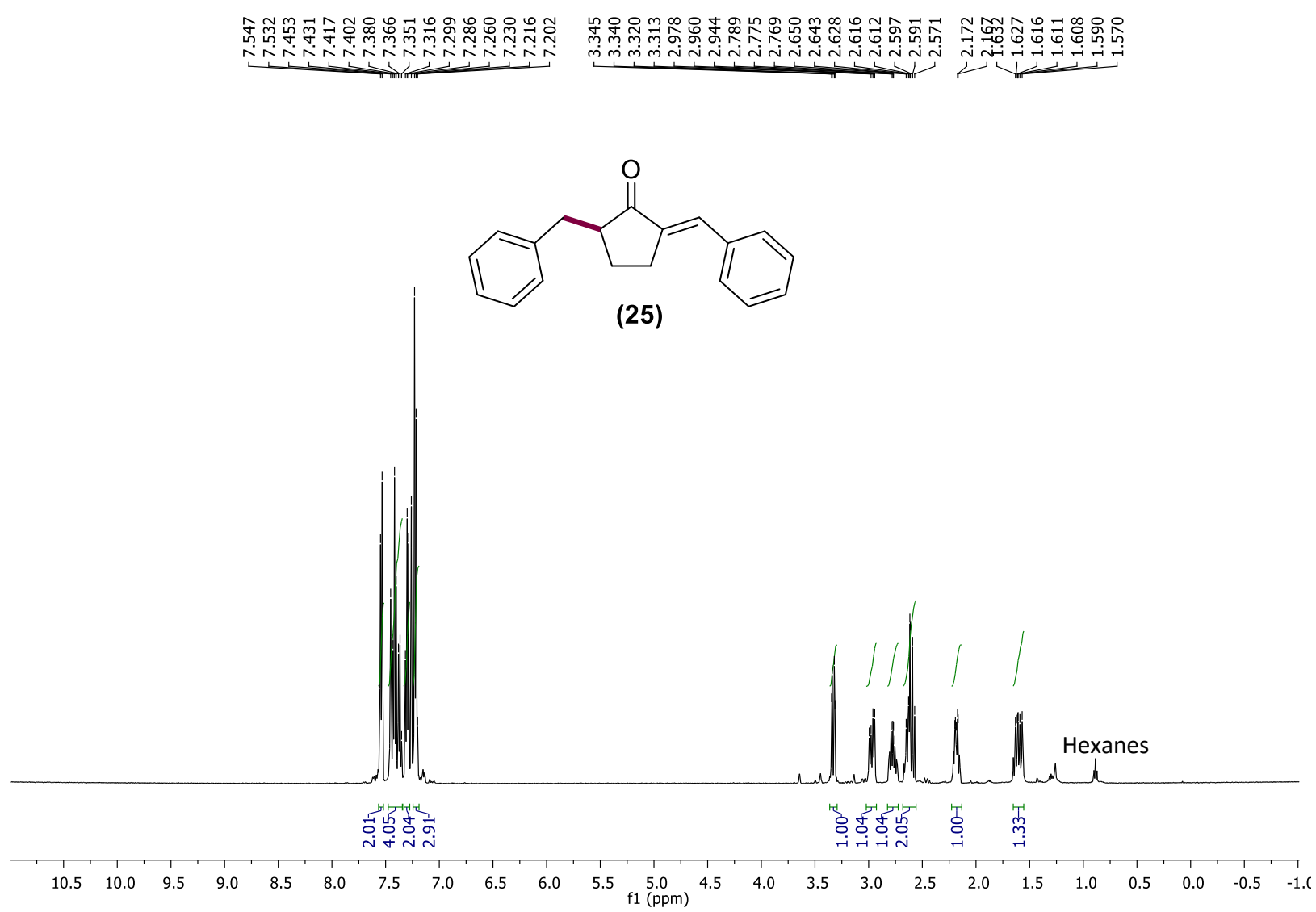


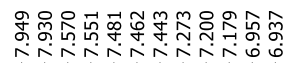

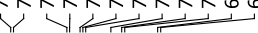<smiles>Cc1nn(C)c(C)c1S(=O)(=O)Oc1ccc(CCC(=O)c2ccccc2)cc1</smiles>
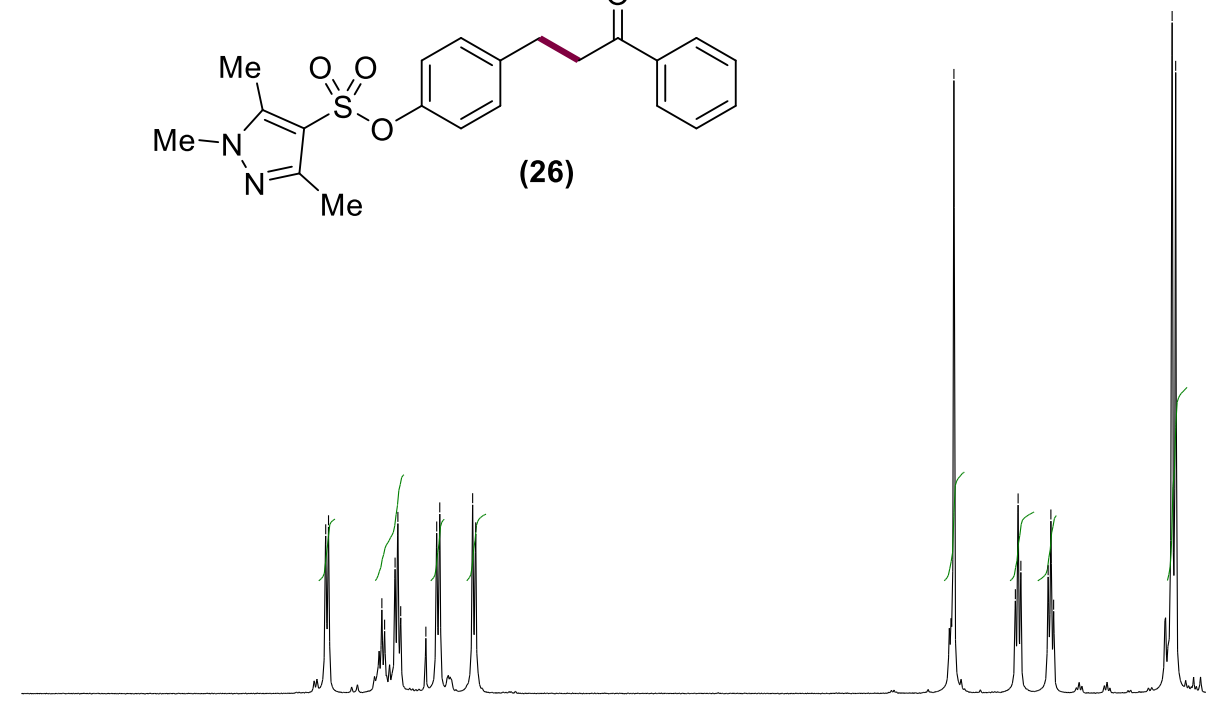

Hexanes
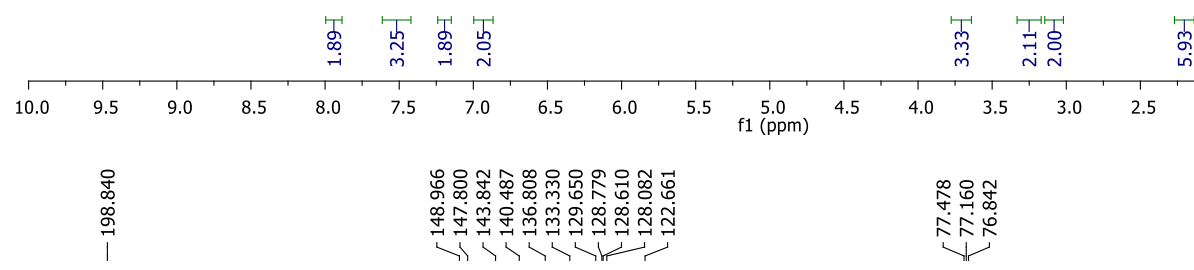

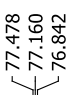

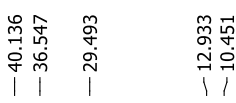<smiles>Cc1nn(C)c(C)c1S(=O)(=O)Oc1ccc(CCC(=O)c2ccccc2)cc1</smiles>
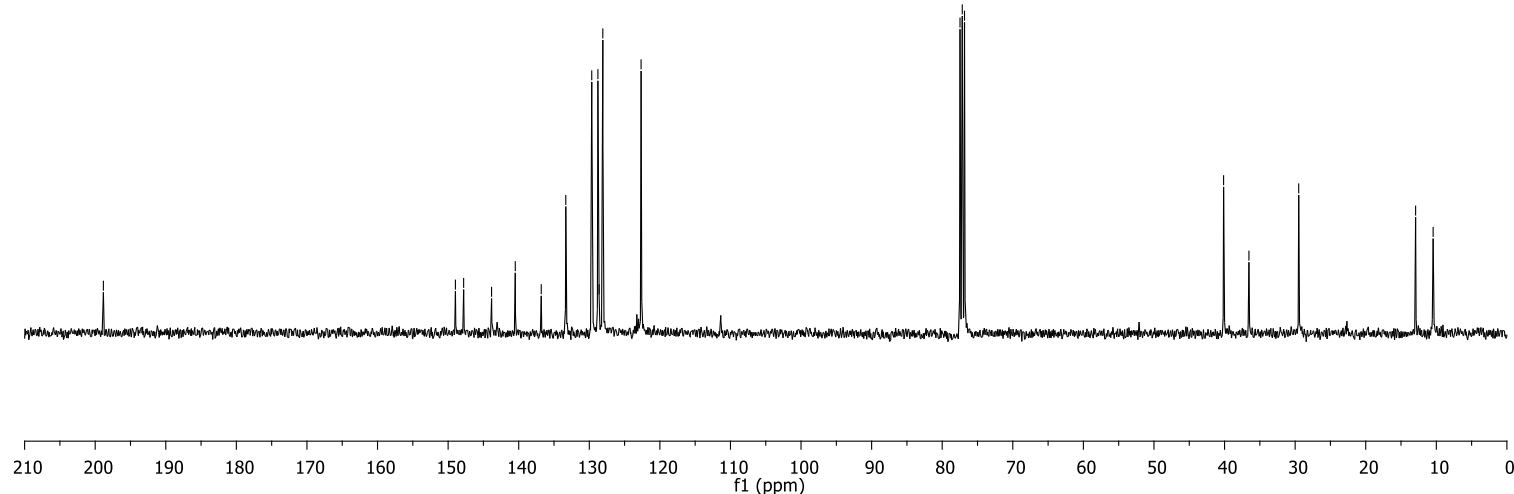


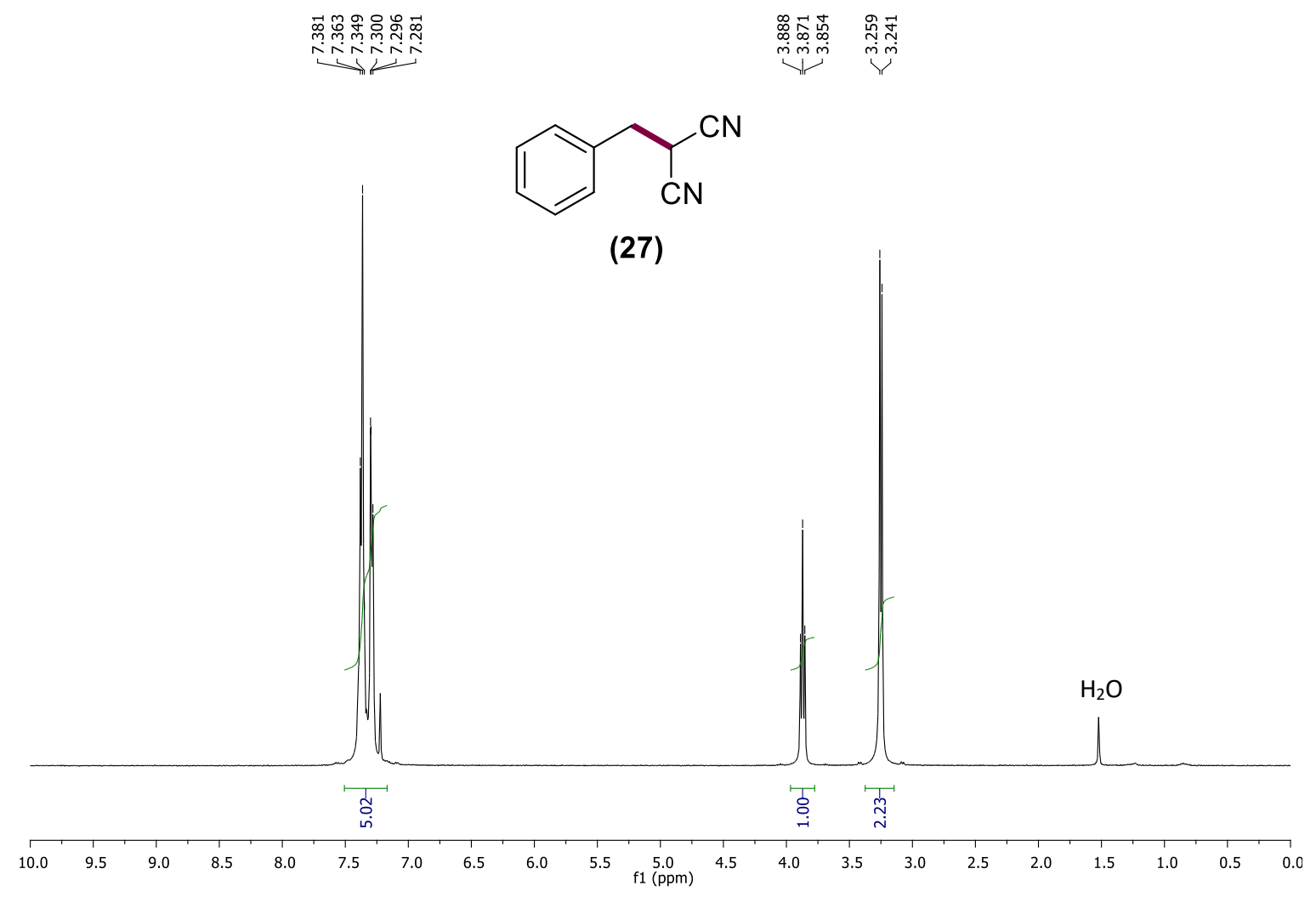




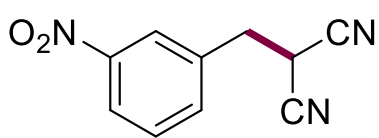

(28)

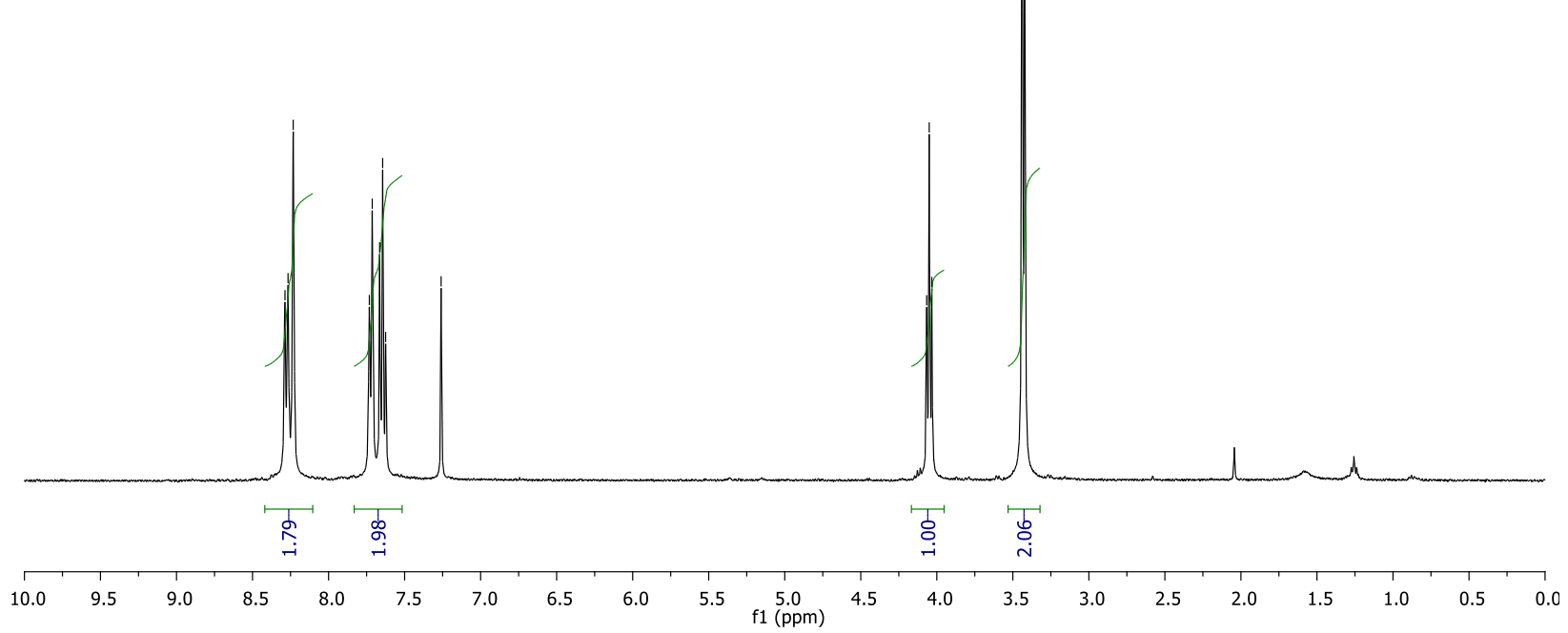




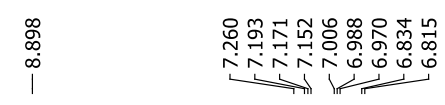

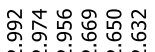

ن่Nin

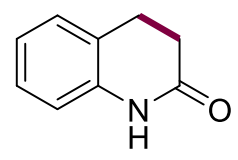

(29)

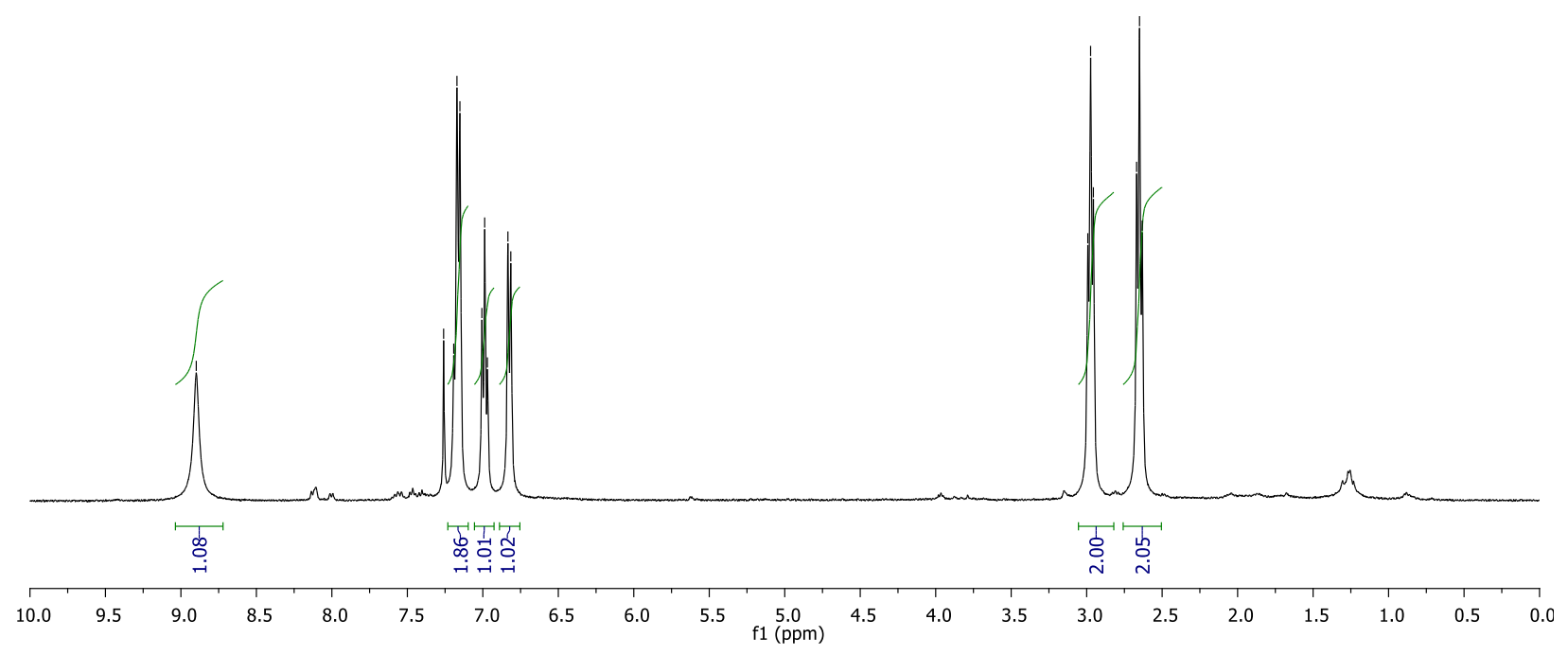




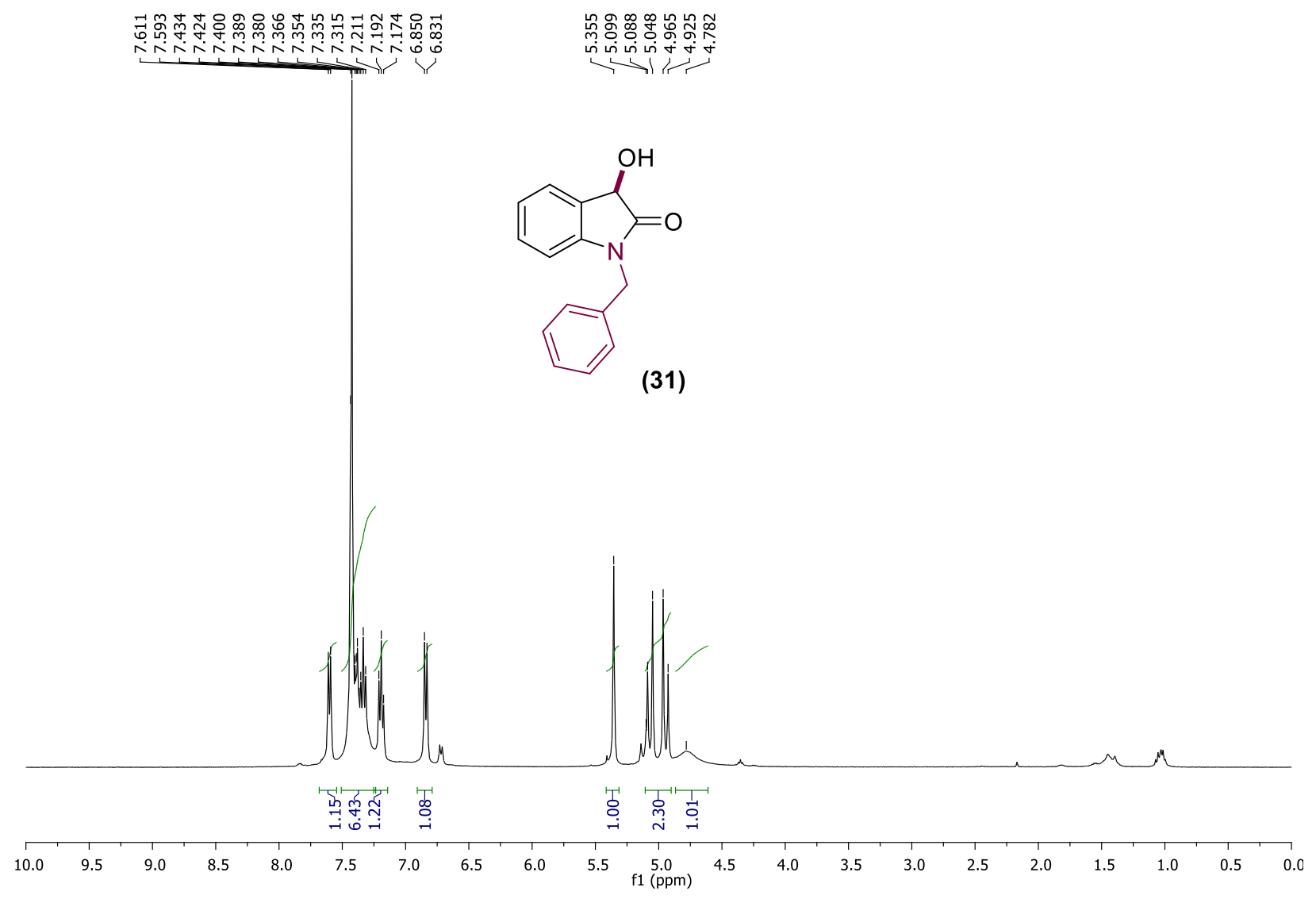

